\title{
Generalization of Streamflow
}

Characteristics From

Drainage-Basin Characteristics

By D. M. THOMAS and M. A. BENSON

GEOLOGICAL SURVEY WATER-SUPPLY PAPER 1975

A study of relations for estimating streamflow characteristics from drainage-basin characteristics in four hydrologically differing regions of the conterminous United States

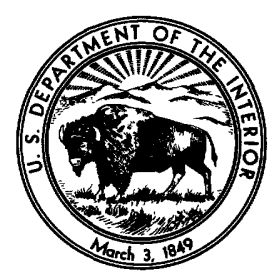




\section{UNITED STATES DEPARTMENT OF THE INTERIOR}

WALTER J. HIGKEL, Secretary

\section{GEOLOGIGAL SURVEY}

William T. Pecora, Director

Library of Congress catalog-card No. 77-606598 


\section{CONTENTS}

Page

Symbols._.

Abstract._...

Introduction.

Acknowledgments_.

Description of study regions.

Eastern region

Central region. 5

Southern region.

Western region.

Selection of streamflow records for analysis

Indices of streamflow characteristics 10

Low flows _... 10

Flow durations

Momentary flood peaks.

Flood volumes _. 11

Mean flows.

Standard deviations__._. 12

Skew coefficients._._.

Serial correlation coefficients

Drainage-basin characteristics._. 13

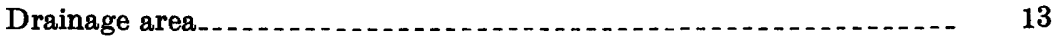

Main-channel slope._._.

Main-channel length. 15

Surface storage..._. 15

Elevation... 15

Forested area

Soils index 16

Basin width. 16

Alluvial area. 16

Channel characteristics.

Meander ratio... 17

Bifurcation ratio... 17

Mean flow distance. 17

Valley width 18

Mean annual precipitation. 18

Mean monthly precipitation

Snow

Precipitation intensity 23

Average annual evaporation. 26

Thunderstorm days... 26

Temperature. 26

Analytical methods._. 26

Results... 
Discussion of results

Variables effective in explaining streamflow variation............. 47

Accuracy of defined relations........... 48

Applicability of generalized relations to gaged sites.

An accuracy test of Potomac River relations...

Implications in design of data-collection systems.......... 52

Summary and conclusions. .

References cited.

\section{ILLUSTRATIONS}

FigURE 1. Map of conterminous United States showing locations of four study regions . . . .

2-5. Maps showing sites for which streamflow records were analyzed:

2. Potomac River basin...

3. Central region.

4. Southern region....

5. Western region

6. Isohyetal map of mean annual precipitation in Southern region.

7. Isohyetal map of mean annual precipitation in Western region.

8. Isohyetal and precipitation anomaly map of mean annual precipitation in Potomac River basin ........ 20

9. Snow anomaly map of the Potomac River basin

10. Map of the Central region showing average annual snowfall..- 23

11. Graph showing relation of average water content of the April 1 snowpack to elevation for subregions of the Western region.-

Page

12. Map of snowpack subregions for the Western region.

13-16. Graphs showing residual errors in:

13. Potomac River basin relations.... 49

14. Central region relations. 50

15. Southern region relations 51

16. Western region relations 52

\section{T A B L E S}

TABLE 1. Ranges and averages of basin characteristics... 14

2-5. Simple correlation coefficients for independent variables used in the-

2. Potomac River basin analysis .

3. Central region analysis..... 30

4. Southern region analysis... 31

5. Western region analysis.......... 31 
TABLes 6-9. Summary of regression relations-

6. Eastern region.

7. Central region. 35

8. Southern region

9. Western region

10. Basin characteristics found to be significantly related to streamflow

11. Observed and predicted streamflow characteristics for short-term streamflow record sites in the Potomac River basin

\section{SYMBOLS}

$A$

$A a$

Ae

$a$

$a$ (subscript)

$B$

$b_{1}, b_{2}, b_{3}, \ldots b_{n}$

cV

$D$

$D_{p}$

$d$ (subscript)

E

\section{$\mathbb{E} v$}

F

G

$g$

$h$ (subscript)

$I_{h}$,

$K_{1}, K_{2}$

$L$

$L_{c a}$

$\mathbf{M}_{d, t}$

$n$ (subscript)

$P$

$P_{t}$

$p$ (subscript)

$Q_{a}$

$Q_{n}$

$R_{b}$
Drainage area, in square miles.

Alluvial soils area, in square miles.

Percent of drainage area exceeding an elevation of 5,000 feet above mean sea level and increased by 1.00 percent.

Constant in regression equation.

Annual value.

Main-channel width, in feet.

Regression coefficients.

Coefficient of variation.

Depth of main-channel entrenchment, in feet.

Duration-curve index, that is, flow exceeded $p$ percent of days, in cubic feet per second.

Duration in days.

Average basin elevation, in 1,000 feet above sea level datum.

Average annual lake and reservoir evaporation, in inches.

Forested area, in percent of total drainage area (increased by 1.0 percent in central and western study regions).

Median size of streambed material, in millimeters.

Coefficient of skew increased by 1.000 .

Duration in hours.

Intensity of h-hour, t-year rainfall, in inches.

Adjustment values from anomaly maps.

Main-channel length, in miles.

Mean-flow distance, in miles.

Minimum annual d-day average flow having a t-year recurrence interval, in cubic feet per second.

Number of month starting with January as 1.

Mean annual precipitation, in inches.

Annual peak discharge having a t-year recurrence interval, in cubic feet per second.

Percentage of time during which flow is equaled or exceeded.

Mean annual discharge, in cubic feet per second.

Mean monthly discharge for month $n$, in cubic feet per second.

Bifurcation ratio. 
$R_{m}$

$S$

$S_{\text {e }}$

$S D$

$S i$

$S n$

Sn

$S R_{a}$

St

$T$ (subscript)
$t_{1}$

$t_{7}$

$V_{d,}$

$W$

$W$.

$X_{1}$,

$Y_{1}, Y_{2}, Y_{3} \ldots Y_{n}$
Main-channel meander ratio.

Main-channel slope, in feet per mile.

Standard error, in percent.

Standard deviation of flow, in cubic feet per second.

Soils infiltration index, in inches.

Mean annual snowfall, in inches (Eastern and Central regions).

Average April 1 water content of snowpacks in inches (Western region).

Serial correlation coefficient of annual flows.

Surface storage index, in percent of total drainage area occupied by lakes and swamps and increased by 1.00 percent.

Average recurrence interval in years.

Mean minimum January temperature, in degrees Fahrenheit.

Mean maximum July temperature, in degrees Fahrenheit. Maximum annual d-day average flow having a t-year recurrence interval, in cubic feet per second.

Average width of drainage area, in miles.

Valley width, in miles.

Basin characteristics.

Streamflow characteristics. 


\title{
GENERALIZATION OF STREAMFLOW GHARACTERISTICS FROM DRAINAGE-BASIN GHARAGTERISTICS
}

\author{
By D. M. Thomas and M. A. Benson
}

\begin{abstract}
Definition of the natural streamflow in all streams, gaged or ungaged, is one of the principal objectives of the streamflow datacollection program of the Geological Survey. This report describes the results of using statistical multiple-regression analyses to provide a generalized definition of the natural streamflow in four widely separated regions of the eastern, central, southern, and western areas of the conterminous United States.

In each study region, every long-term, virtually natural stream. flow record was characterized by 71 or more flow indices. These indices represented magnitudes of high, low, and medium flows and also the distributions of flows in time. Numerrous topographic and climatic indices were defined to describe the drainage basin above the site of each flow record. Multiple-regression analyses then defined the relation between each flow characteristic and the drainage-basin characteristics. The analyses also provided measures of the accuracy of each relation.

Results of the regression analyses indicate that streamflow characteristics can be defined more accurately in the humid Eastern and Southern regions than in the more arid Western and Central regions, that medium flows can be more accurately defined than high flows, and that low flows can be only weakly defined. Standard deviations of monthly and annual flows were found to be significantly related to basin characteristics. Some indices of flow distributions in time (serial correlation and skew coefficients) could better be described by regional averages.

Regression relations presented in this report may be used to estimate many natural-flow characteristics at any site in the study regions. In addition, the knowledge of basin characteristics found significantly related to streamflows and the knowledge of the accuracy of defined
\end{abstract}


relations provides a firm technical basis for modifying and improving the existing streamflow data-collection system.

\section{INTRODUCTION}

One function of the Geological Survey is to perform surveys, investigations, and research covering the Nation's water resources. An essential part of this appraisal work is the definition of streamflow at any and all locations.

As a means of accomplishing its task, the Geological Survey currently operates more than 8,000 complete-record stream-gaging stations and several thousand partial-record stations. Some stations are operated on streams where man has altered the natural flow. These stations provide information needed to regulate, to divert, and to account for flow in those specific streams on which the gages are located. Many other gaging stations are operated on streams where the flow is unaffected or insignificantly affected by man's activities. Because of the similarities of natural streamflow among streams over fairly large regions, the information gathered at a natural-flow gaging station has transfer value - that is, it is not only useful at the gaging site but also at nearby ungaged sites. These natural-flow gaging stations provide the basic data for national water-resources appraisal.

Gaging of all sites on all natural-flow streams is neither possible nor desirable. The available gaging record, therefore, can provide only an areal sampling of the streamflows. Because only a sample of natural streamflows is gaged, the desired generalization of information requires a sound method of transferring available information to other sites. Many transfer methods have been proposed. They range from the simple extrapolation or interpolation of information gathered at two sites on the same stream to complex statistical methods that simultaneously consider many streamflow records and the environmental characteristics of the contributing drainage basin above each gage. There are several methods intermediate between these two.

After a survey of known transfer methods, it was concluded that the method showing the most promise is one relating specific streamflow characteristics to topographic and climatic characteristics of the drainage basins by multiple regression. Previous studies have shown that multiple-regression methods may successfully relate floodflows to topographic and climatic characteristics. It is, therefore, not unreasonable to expect successful use of the multiple-regression method with other categories of streamflow.

The primary purpose of this study was to test the feasibility of the multiple-regression method of streamflow generalization over the complete range of streamflow. It was desired to know how accurately 
streamflow characteristics might be estimated at any ungaged, naturalflow site from the presently available long-term streamflow records. Another purpose of the study was to determine the topographic and climatic drainage-basin characteristics most effective for explaining the site-to-site variations in streamflow.

Results of these studies are expected to be helpful in appraising the adequacy of the present natural-flow data-collection system. For example, if any category of streamflow can be satisfactorily generalized, then a reduction should be considered in the effort of collecting data on that category. If a ca+egory of streamflow cannot be satisfactorily generalized, then an increase in data collection or in research on that category would be indicated. In either case, the study might indicate a better approach to definition of future data-collection needs. Identification of the topographic and climatic variables that explain streamflow variations will facilitate the location of gaging stations so that a wide range of the effective characteristics is sampled.

Relations between streamflow and basin characteristics were individually studied in the four widely separated regions of the conterminous United States shown in figure 1. These study regions are the Potomac River basin in the East, Missouri River and Arkansas River tributary basins in the Central region, Red River tributaries and gulf coast drainages in the South, and the California Central Valley in the West. Potomac River basin relations were studied first, and the procedures developed in that study were followed in the remaining three studies.

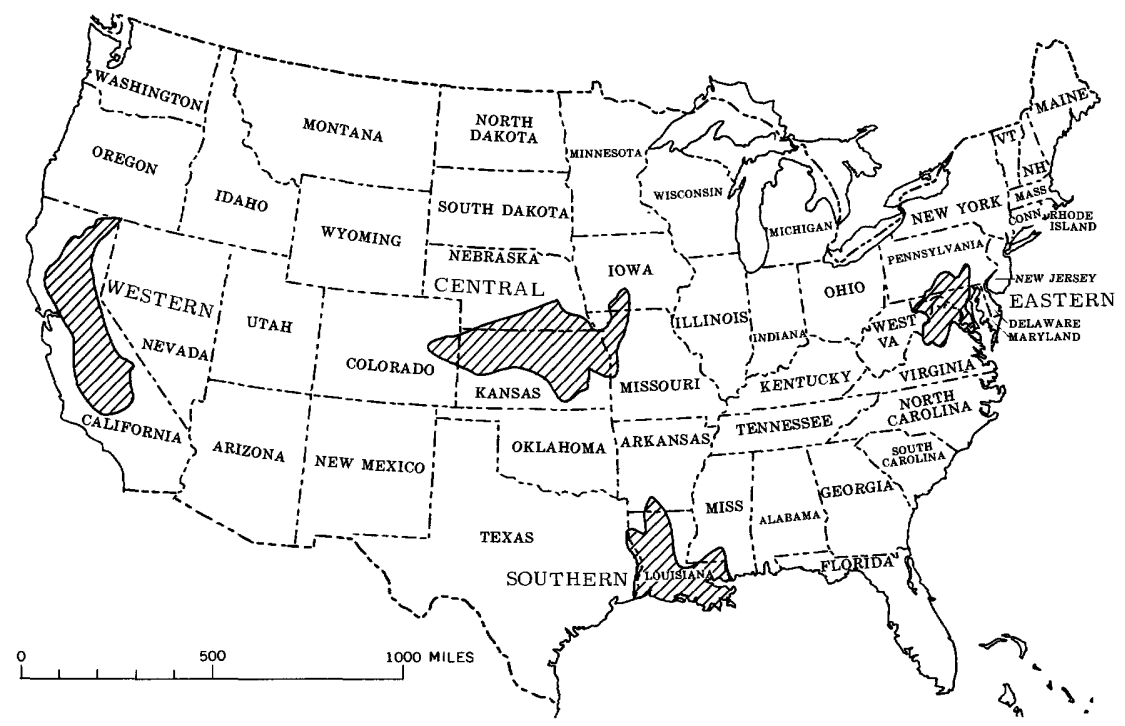

Figure 1.-Locations of four study regions. 


\section{AGKNOWLEDGMENTS}

Manuel A. Benson and Donald M. Thomas conducted the Potomac River basin study and directed the studies for the other regions. Compilation of data, analysis of relations, and reporting of results for their areas was done by Ivan C. James, II, of Topeka, Kans., Russell W. Cruff, of Menlo Park, Calif., and Vernon B. Sauer, of Baton Rouge, La. H. O. Ogrosky, of the U.S. Soil Conservation Service, furnished the hydologic soils indices for each study area.

\section{DESCRIPTIONS OF STUDY REGIONS}

\section{EASTERN REGION}

The Potomac River basin (fig. 2) covers more than 14,000 square miles in parts of the States of West Virginia, Maryland, Virginia, and Pennsylvania, and is similar in topographic characteristics to many drainage basins along the Atlantic Coast of the United States. The basin topography ranges from flat, deep-soil areas in the lower basin to

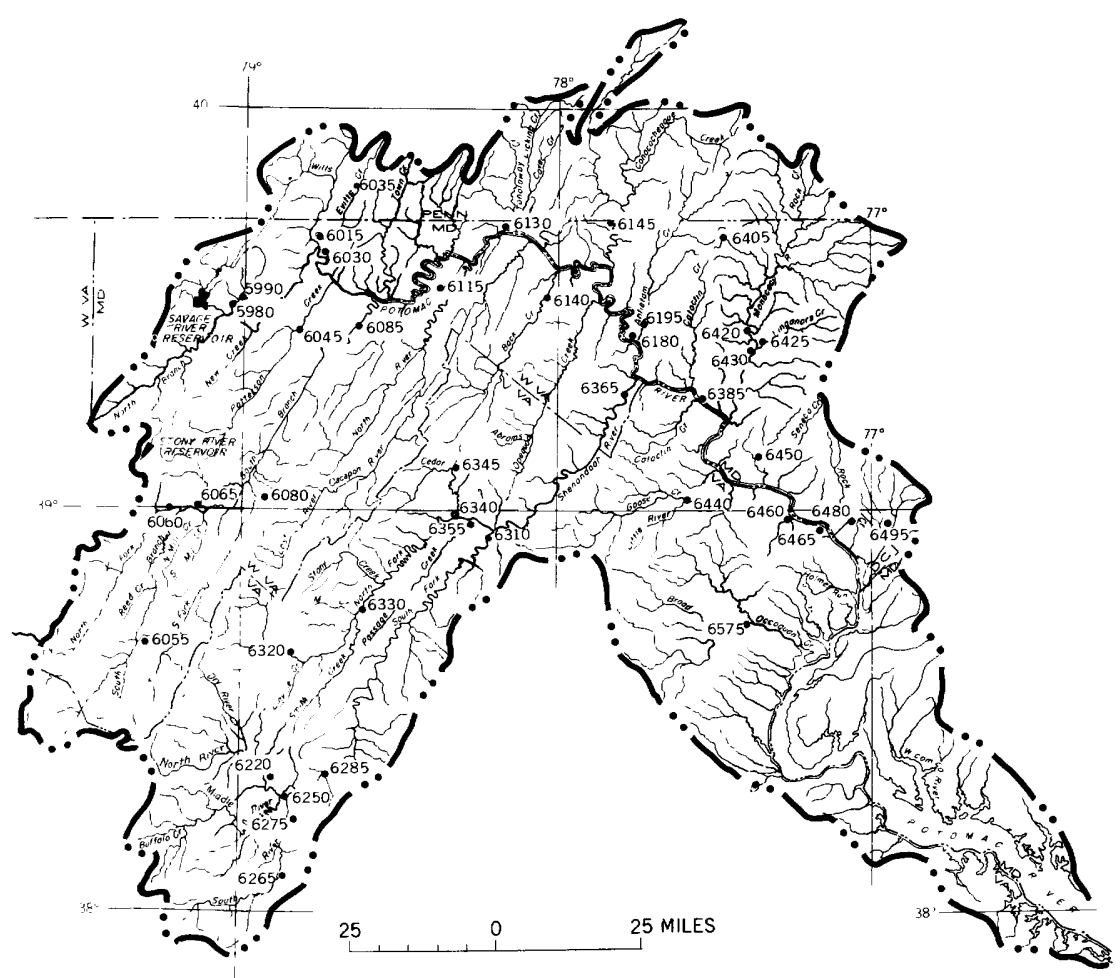

FIgURe 2.-Potomac River basin and sites for which streamflow records were analyzed. 
rocky, steep-sloped mountains of the upper basin. Fenneman (1938) described five physiographic provinces in the basin, namely, the Coastal Plain, Piedmont, Blue Ridge, Ridge and Valley, and Appalachian Plateau. Topographic maps of 1:62, 500 scale or larger are available for the entire basin.

Climate of the basin is temperate with an average temperature of $55^{\circ} \mathrm{F}$. Winters are rigorous but not severe, whereas summers are humid and warm to hot.

Average annual precipitation over the basin ranges between 30 and 55 inches. Although monthly precipitaion is a little greater in summer than in winter, there is no distinct wet and dry seasonal precipitation pattern. Mean annual snowfall ranges from more than 10 inches along the coastal areas to nearly 60 inches in the mountains.

Potomac River basin floods may occur during any season and may result from storms of cyclonic, hurricane, or thunderstorm types or from combinations of these types. In general, streamflow is greatest in spring and lowest in late summer and fall.

In this report, "Eastern region" or "Potomac River basin" are used synonymously to describe this study area.

\section{CENTRAL REGION}

The Central region (fig. 3), most of which is in Kansas, is in the Great Plains and Central Lowlands provinces of the Interior Plains. Most of the streamflow sites for which data were analyzed for this report are in the lower Missouri River basin in Kansas, eastern

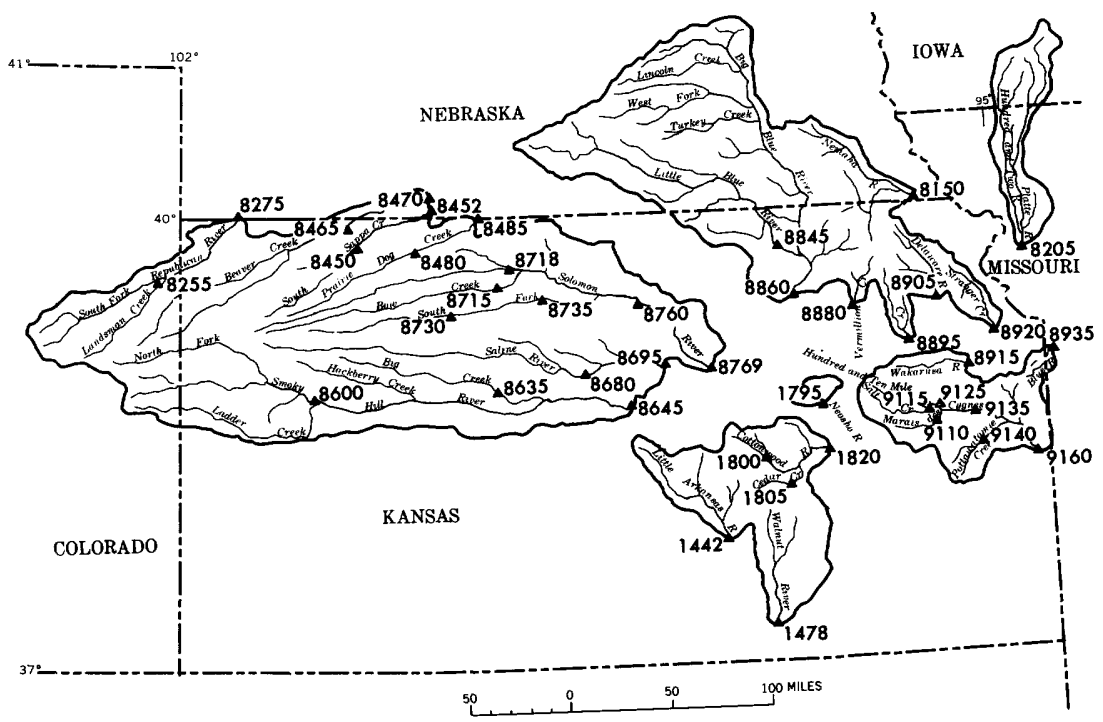

Figure 3.-Central region and sites for which streamflow records were analyzed. 
Colorado, southern Nebraska, and western Missouri. A few sites are in the Arkansas River basin adjacent to the lower Missouri River basin.

The land surface in the study region is flat or gently rolling. The climate is typical of the Interior Plains. Average annual rainfall varies from 16 inches in the western part of the region to 39 inches in the southeastern part. On the average, about three-fourths of the annual precipitation falls in the 6-month growing season, April-September. Late May and early June is usually the wettest period of the year, although some of the heaviest daily storms have occurred in September as a result of moist air masses from Gulf of Mexico hurricanes meeting cool fronts from the arctic regions. The mean annual temperature in Kansas is $55^{\circ} \mathrm{F}$ and is slightly less for the study region. Temperatures in Kansas have ranged from $121^{\circ}$ to $-40^{\circ} \mathrm{F}$. Weather systems in this region can change rapidly, giving the area a "vigorous" climate.

Stream discharge in the study region is normally greatest in May, June, and early July, tapering off rapidly to very low flow in late July, August, September, and October, except for response to intermittent rains. The first killing frost, which normally occurs in October, usually results in an increase in flow, and moderate low-flow discharges continue with ice effect and some snowmelt runoff until the first heavy spring rains. There is no streamflow about 10 percent of the time at nearly a third of the stations used in the study, and about once each 10 years, on the average, there is no flow for a 7-day period at roughly one-half of the stations.

In this report, "Central region" or "Kansas," are used to describe this study area.

\section{SOUTHERN REGION}

The Southern region (fig. 4) covers 26,000 square miles of gulf coast area; about 90 percent of the region is in Louisiana, and the remainder is in Arkansas and Mississippi. Streams within the region drain into the Sabine, Red, Mississippi, Atchafalaya, and Pearl Rivers or directly to the Gulf of Mexico. About 15 percent of the study region lies in the alluvial plains of the Red, Mississippi, and Atchafalaya Rivers; but no streamflow records gathered at sites in the alluvial plains were considered in this study, nor do the results apply to streams in the alluvium.

Most of the study region is described as "pine hills." The land surface is gently rolling, and elevations vary from about 400 feet above mean sea level near the Arkansas-Louisiana State line to 20 or 30 feet above mean sea level near the southern boundary of the region. Forests of long-leaf and short-leaf pines cover most of the region but they are broken by well-scattered areas of cultivated land and by numerous small stock ponds. 


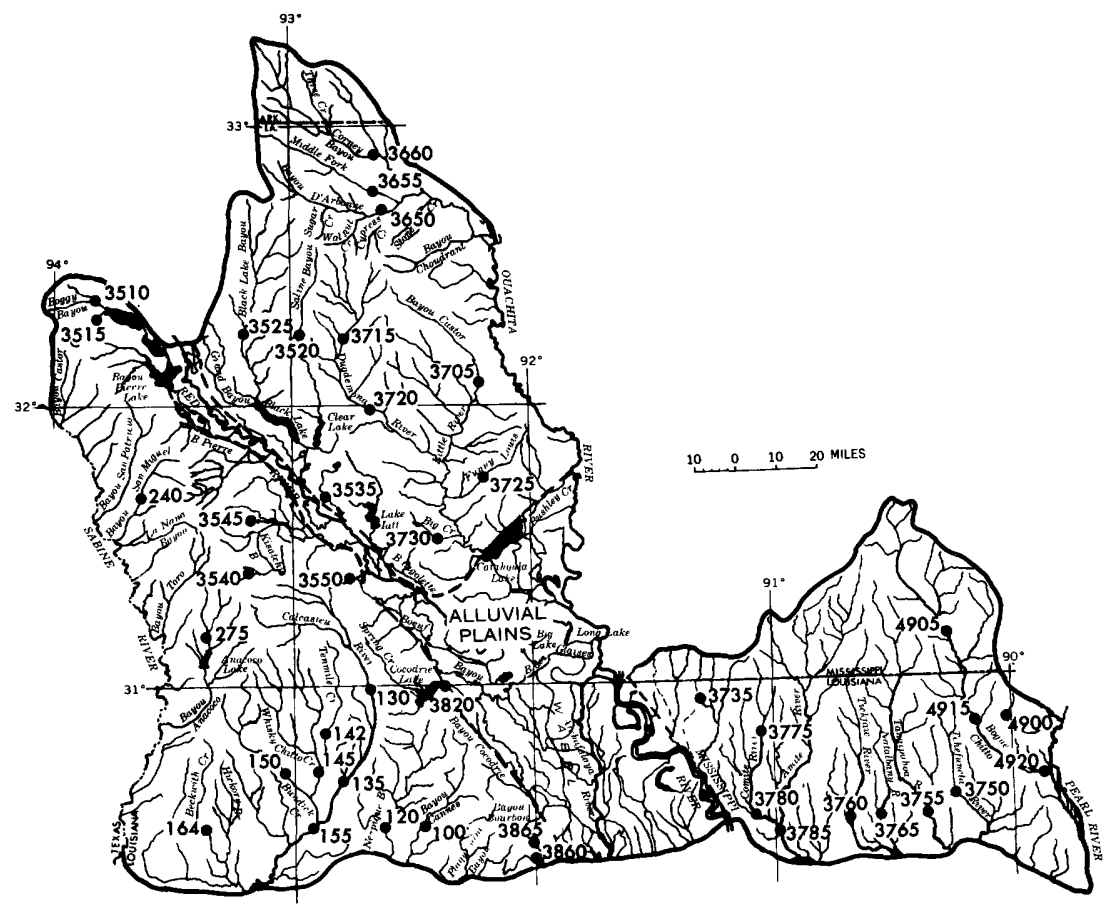

FIgure 4.-Southern Region and sites for which streamflow records were analzyed.

The climate is semitropical with mean temperatures ranging from $66^{\circ} \mathrm{F}$ in northern Louisiana to $69^{\circ} \mathrm{F}$ in southern Louisiana. Annual precipitation ranges from 46 inches in the northwest to 66 inches in the southeast.

Thunderstorms usually produce the most intense rains, but they are of short duration and generally affect only local areas. Tropical storms sometimes produce prolonged, heavy rains over wide areas, especially in the southern half of the region. During the winter, socalled northwesters are sometimes accompanied by broad-scale, moderately heavy rainfall. Snow and ice are rare and have little or no effect on streamflow.

In this report, "Southern region," "Gulf Coast region," or "Louisiana" are used to describe this study area.

\section{WESTERN REGION}

The Western region (fig. 5), the California Central Valley, encompasses the Sacramento and San Joaquin River basins. The Central Valley covers more than 40,000 square miles, or more than one-fourth the area of California. The area extends from the California-Oregon 


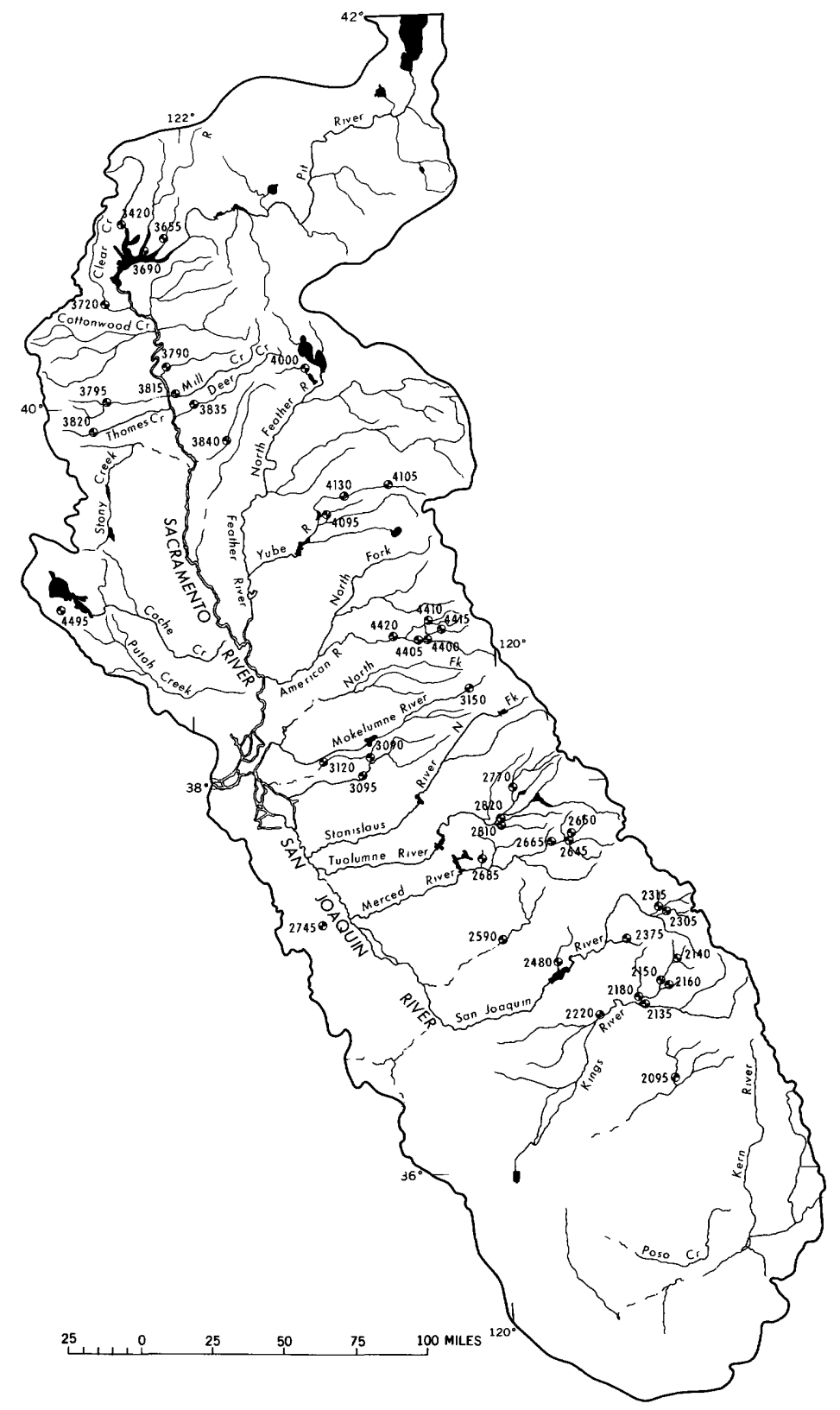

Figure 5.-Western region and sites for which streamflow records were analyzed.

State line southward to the Tehachapi Mountains and from the crest of the Coast Ranges on the west to the crest of the Sierra Nevada on the east. 
A wide variety of topography is found in this study region. Both Mount Shasta near the northern end of the Sierra Nevadas, and Mount Whitney near the southern end, exceed elevations of 14,000 feet above mean sea level, and much of the crestline reaches elevations near 12,000 feet. The crest of the Coast Range generally rises above 3,000 feet. Between the Coastal and Sierra Nevada ranges, much of the relatively flat, and extensively farmed, valley floor lies below 500 feet elevation. Lowlying tule lands occupy the Sacramenta-San Joaquin Delta at the valley mouth.

Variations in climate parallel the variations in topography. Extremes of temperature have been recorded as higher than $120^{\circ} \mathrm{F}$ in the southern part of the valley floor, and as lower than $-30^{\circ} \mathrm{F}$ in the mountains. Precipitation occurs in a seasonal pattern with most occurring during the period November to March. In general, precipitation amounts decrease from north to south and range from more than 80 inches in some northern mountain areas to less than 10 inches for a large part of the southern valley floor.

Streamflow ranges from perennial to ephemeral and, in general, is greatest in the winter and spring. Most floods result from spring snowmelt or frontal-type winter storms. Summer thunderstorms rarely cause flooding in this region.

In this report, "Western region," "Central Valley," or "California" are used to describe this study area.

\section{SELECTION OF STREAMFLOW RECORDS FOR ANALYSIS}

All the continuous streamflow records available in each of the four study regions were examined to select records for use in the analysis. Records of the greatest possible length were desired, because the characteristics of flow computed from such records can be expected to include less time-sampling error than characteristics computed from shorter records. Also desired was as large a group of records as possible because the increased range of basin characteristics usually found in a large sample improves the confidence in, and utility of, the defined multiple-regression relations.

Only those records or parts of records judged to represent virtually natural streamflow were selected for analysis. No attempt was made to select the records so that they covered a common time period, to fill in missing years of record, or to adjust the streamflow characteristics to represent any selected time period. The use of records from whatever periods may be available is consistent with considering them as random sample data. Such data should lead to a better description of longterm expectancy than data for a base period. One seeming disadvantage of using records from whatever period is available is that a larger 
standard error may be expected from the final multiple-regression relations; however, this disadvantage is considered preferable to the bias that may be introduced into the relations by use of a base period if flow during the base period is either higher or lower than the longterm average.

In the Potomac River basin, 41 streamflow records, each 18 years or more in length, were selected for the analysis. Locations of the gages where these records were obtained are shown in figure 2. In the Central region, 41 records ranging in length from 12 to 61 years were selected, and the gage locations are indicated in figure 3 . In figure 4 are shown the 42 selected gulf coast gaging sites having records ranging from 15 to 29 years, and in figure 5 are shown the 44 California gaging sites where records for 16 or more years were obtained for analysis. There was no attempt to specify a minimum length of record for use in the analyses. For each region, the local project office selected records to be used.

\section{INDICES OF STREAMFLOW CHARACTERISTICS}

Thu streamflow characteristics studied were intended to be a fairly exhaustive list of all those that might be used for design or planning. They are indices of all parts of the range of flows, from the lowest to the highest. They include descriptors of flow magnitudes, flow variability, and the distribution of flow in time. Some of the characteristics for example, the 10-year peak flood discharge, could be used directly in a design problem. Others might be used in combination for developing engineering design criteria-for example, the means, standard deviations, skew coefficients, and serial correlations might be used to generate long synthetic series of streamflow records. For each of the records used in the analysis, 71 or more indices of streamflow were abstracted. Of these, two represent low flow, three represent durations of daily flows, six define flood peaks, eight define flood volumes, 13 represent annual and monthly means, and the remainder are statistics that define the flow distribution in time: standard deviations, skew coefficients, and serial correlation coefficients.

\section{LOW FLOWS}

Low-flow characteristics at each gaging site were represented by the annual minimum 7-day mean flows having recurrence intervals of 2 years $\left(M_{7,2}\right)$ and 20 years $\left(M_{7,20}\right)$. These low-flow indices represent discharge below which the minimum annual 7-day average will fall at time intervals averaging 2 years and 20 years in length, respectively.

For sites in the Eastern and Central region, the low-flow indices were determined from frequency curves graphically defined by methods 
Riggs (1965) outlined. For Western and Southern sites, the low-flow indices were determined by mathematically fitting a three-parameter Pearson Type III distribution to the logarithms of annual minimum flows. A value of 0.01 cubic feet per second was added to each annual minimum flow before transforming discharges to logarithms in order to avoid the problem of defining the logarithm of any zero flows. Mathematical fitting of the curves was done by a digital computer. Results from the use of the graphical curves and the Pearson Type III fitting are considered comparable.

\section{FLOW DURATIONS}

Flow-duration curves showing the percentage of days during the period of record that equaled or exceeded indicated discharges were drawn for each gaging station. From these curves were determined the discharge equaled or exceeded 10 percent of the time $\left(D_{10}\right), 50$ percent of the time $\left(D_{50}\right)$, and 90 percent of the time $\left(D_{90}\right)$, except that 80 percent of the time $\left(D_{80}\right)$, was used in the Central region instead of $\mathrm{D}_{90}$.

\section{MOMENTARY FLOOD PEAKS}

Annual peak flood discharges corresponding to six recurrence intervals were determined from each of the gaging-station records. They represent the annual maximum rate of stream discharge exceeded on the average of once each $1.2,2,5,10,20$ or 25 , and 50 years. In this report these peak-flow rates are respectively denoted by $P_{1.2}, P_{2}, P_{5}, P_{10}$, $P_{20}$ or $P_{25}$, and $P_{50}$.

For Potomac River basin sites, these indices of peak-flow rates were determined from graphical flood-frequency curves drawn by the method Dalrymple (1960) outlined. Although no special study was made of historic flood events, any information on historic floods noted in the annual streamflow reports was used in shaping the curves. For sites in the Western, Central, and Southerns region, peak-flow rates of selected recurrence intevals were determined by:mathematically fitting a Pearson Type III distribution to the logarithms of observed peak flows. No historical information was considered, and calculations were performed by digital computer. Results from the use of the graphical curves and the Pearson Type III fitting are considered comparable.

\section{FLOOD VOLUMES}

Eight measures of annual maximum flood volumes were determined from each gaging record. These indices were the annual maximum 3-day mean flow and the annual maximum 7-day mean flow that would 
be exceeded on the average of once each 2, 10, 20, and 50 years. Symbolically, these flows are indicated as $V_{3,2}, V_{3,10}, V_{3,20}, V_{3,50}, V_{7,2}$, $V_{7,10}, V_{7,20}$, and $V_{7,50}$.

These flow-volume indices were determined from graphical floodfrequency curves (Dalrymple, 1960) for all Potomac River basin sites and from a Pearson-Type III distribution fitted to the logarithms of the observed flows for all other sites. Results by the two methods are considered comparable.

\section{MEAN FLOWS}

The mean of the annual flows and of each calendar month flow was computed for each gaging station and provided 13 indices of average streamflow. In this report the symbol $Q_{a}$ represents the mean of the annual discharges, and $Q_{n}$ (where the subscript $n$ refers to the numerical order of the months with January as 1) represents the mean of the monthly discharges.

\section{STANDARD DEVIATIONS}

Indices used to evaluate the year-to-year variability of flows at each gaging site included the standard deviations of annual flows and of flows for each calendar month. Symbols representing the standard deviations of the annual and monthly flows are, respectively, $S D_{a}$ and $S D_{n}$, where the subscript $n$ refers to the chronological order of the months with January as 1.

\section{SKEW COEFFICIENTS}

Skew coefficients aid in describing the year-to-year distribution of mean flows. Skew coefficients for the annual and monthly means were computed from the third central moment for each gaging-station record. To avoid difficulties which arise from use of zero and negative numbers in later parts of the analysis, a value of 1.000 was added to each computed skew coefficient. The symbols $g_{a}$ and $g_{n}$ are used in this report to indicate skew coefficients increased by 1.000 .

\section{SERIAL CORRELATION COEFFICIENTS}

Serial correlation coefficients measure the degree of relation between a streamflow characteristic of one period and the same characteristic of a succeeding period. Serial correlation coefficients of annual and monthly means with a 1-year time lag were investigated for this analysis. For example, the degree of relation between January flows of succeeding years was determined. All serial correlations of monthly and annual means proved to be very small. 


\section{DRAINAGE-BASIN GHARCTERISTICS}

Méteorologic and topographic characteristics of a drainage basin control the amount of streamflow from the basin and the distribution of this flow in time. Precipitation, the primary source of streamflow, may vary greatly from basin to basin in time, type, and duration. Streamflows reflect these precipitation variations, and the differences in streamflows between basins may be varied further by differences in the surface characteristics, the drainage patterns, the amount of stored water upon, or beneath, the basin surfaces, the water loss by evaporation and transpiration, and possibly the subterranean flow into, or out of, the basins. The physical characteristics of a basin which conceptually might influence streamflow usually need to be expressed by some simplified representative indices. These indices become the "independent variables" in the statistical analysis. The problem in this study was to select numerical indices of the physical characteristics of each sample drainage basin that could be related to the observed differences in streamflow characteristics.

Although some basin characteristics, such as the basin geology, cannot yet be satisfactorily represented by simple numerical indices, many other basin characteristics can be evaluated from maps or tabular data. Practical limitations of time and of the statistical analytical procedures require the selection of a limited number of basin variables. Variables to be evaluated and used in the studies were selected on the basis of hydrologic, hydraulic, geologic, and meteorologic principles, on the degree of success experienced in use of the variables in previous studies, and on the ease of enumeration. Regression analysis produces optimum results if the independent variables are not highly related amongst themselves, and to the extent possible, this criteria was also considered in selecting those variables to be evaluated.

Basin characteristics selected for evaluation and the method of evaluation are given below. Table 1 gives the range of numerical values of the variables in the sample basins for each study region.

\section{DRAINAGE AREA}

Size of drainage area can intuitively and from experience in previous studies be considered a logical cause of streamflow variations between sites. Drainage areas, in square miles, shown in the latest Geological Survey streamflow reports were used in this study, and are symbolically represented by $A$. Where appropriate, noncontributing area was excluded and only contributing area used. 


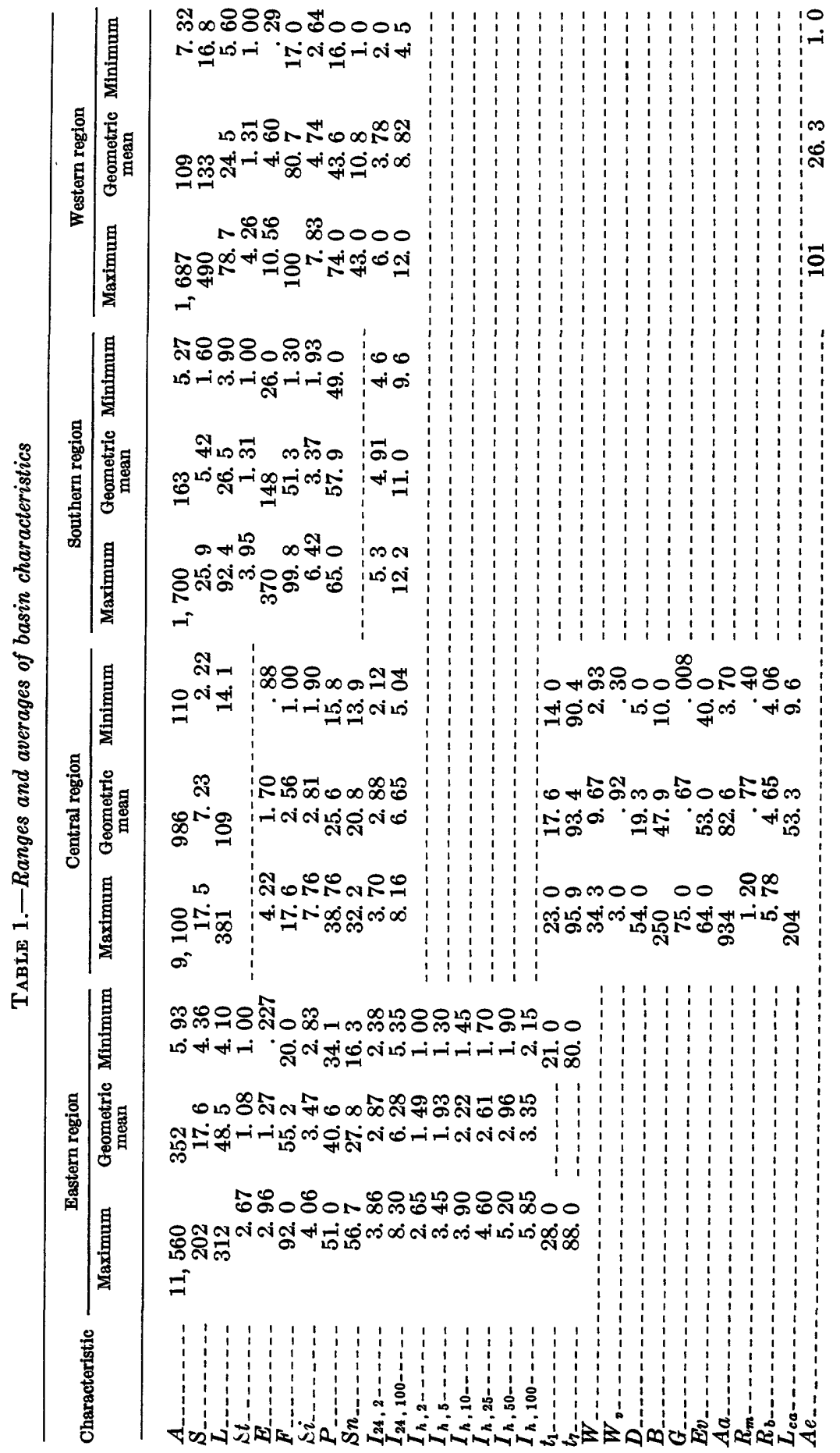




\section{MAIN-GHANNEL SLOPE}

Slope of a drainage basin is another factor which can intuitively be assumed to influence streamflow. For this study a simple index of slope developed and successfully used by Benson $(1962,1964)$ was selected. This index is the average slope, in feet per mile, of the main channel between points 10 and 85 percent of the distance upstream from the gaging site to the basin border. To determine this slope index, main-channel length (extended to the divide) was first measured on topographic maps. Elevations at the 10- and 85-percent points were then determined from contours, and the average slope was computed between these points. The symbol $S$ is used for main-channel slope in this study.

\section{MAIN-CHANNEL LENGTH}

Main-channel length $(L)$ was selected as a variable indicating basin shape in conjunction with $A$. Values of main-channel length, in miles, were available from the determination of main-channel slope. In a study of flood flows in Texas and New Mexico, Benson (1964) found length a significant variable.

\section{SURFACE STORAGE}

Differences in storage capacities can be expected to be a measure of streamflow variation between basins. The index of each basin's surface storage $(S t)$ was computed as the percentage of total drainage area occupied by lakes, ponds, and swamps. To avoid difficulties associated with the use of zeros in the regression analysis, all values of percent of drainage area in lakes, ponds, and swamps were increased by a value of 1.00 percent.

Storage occurs also in the stream channels, in ground water, and in the soil. No simple numerical indices of channel storage or of groundwater storage have yet been determined. Soil moisture capacity may be represented in part by the soils index described subsequently.

\section{ELEVATION}

Although elevation itself may not directly cause streamflow variations, elevation may serve as an index to other factors that cause basinto-basin streamflow variation but that are difficult to evaluate. Radiation, temperature, wind, vegetation, and basin ruggedness, for example, may vary with elevation. For this reason mean basin elevation, in thousands of feet above sea level, was determinted and included as a topographic variable in this study.

For sites in the Eastern and Western regions, mean elevation $(E)$ was evaluated by laying a grid over a topographic map of each basin 
and determining the mean of the elevations under each grid intersection. The grid spacing was selected so as to provide no less than 25 intersections within the basin boundary. For sites in the Central and Southern regions, the basin-elevation index was computed as the mean of evelations at the 10- and 85-percent points along the main stream channel. These elevations were available from the computation of the channel-slope index.

A second index of elevation was investigated in the Western region. This index is the percentage of each drainage area that lies higher than 5,000 feet above mean sea level. The value was computed as the percentage of the points selected by the grid method for determining mean basin elevation $(E)$ that were greater than 5,000 feet. The computed value was increased by 1.0 percent to avoid zero values, and has been designated by the symbol $A e$.

\section{FORESTED AREA}

Forests affect streamflow by transpiration, by precipitation interception, by modifying the accumulation and melting of snow, and possibly by other ways. The index of forest cover $(F)$ used in this analysis is the percentage of total drainage area shown as forested on the topographic maps. To avoid difficulties associated with the use of zeroes in the regression analysis, measured values of forested area for basins in the Central and Western regions were increased by 1.0 percent.

\section{SOILS INDEX}

Infiltration capacity of the basin soils influences the amount of direct runoff from a storm and the amount of delayed subsurface runoff. The soils index represents values of potential maximum infiltration, in inches, during an annual flood, under average soil moisture conditions.

Values of the soils index $(S i)$ were computed for each basin from data provided by the U.S. Soil Conservation Service and the Forest Service using procedures described by the U.S. Soil Conservation Service (1956).

\section{BASIN WIDTH}

For the Central region only, the average basin width $(W)$, in miles, of all sample drainage basins was computed as the ratio of drainage area $(A)$ to main-channel length $(L)$, or $W=A / L$.

\section{ALLUVIAL AREA}

The area of alluvial soils, in square miles, was determined for each sample drainage basin in the Central region. Alluvial area $(A a)$ was planimetered from 1:500,000-scale State geologic maps. 


\section{CHANNEL CHARACTERISTICS}

A stream channel is shaped by processes that are related to the amount and distribution of streamflow. Measurements of the stream channel might be expected, therefore, to provide indices for determining streamflow characteristics at ungaged sites.

Three types of channel measurements were available for each sample basin in the Central region, and they were included in the multipleregression analysis. These channel characteristics were the depth of main-channel entrenchment $(D)$, width of main channel $(B)$, and the median size of streambed material $(G)$. Depth of entrenchment, in feet, is the vertical distance from top to bottom of the riverbank in a straight reach of channel near the gaging site. Width of the channel, in feet, is the horizontal distance at the bottom of the banks. Median grain size, in millimeters, of the streambed material was determined from plotting on a logarithmic probability graph the results of a sieve analysis on a sample obtained near the gaging site.

\section{MEANDER RATIO}

A measure of the sinuosity of the main stream channel, called the meander ratio $\left(R_{m}\right)$, was available from previous studies for all sample basins in the Central region. This index was computed as the ratio of the main-channel length $(L)$ to the length of the valley.

\section{BIFURCATION RATIO}

The bifurcation ratio (Horton, 1932) is a descriptor of the stream pattern in a drainage area. For all sample basins in the Central region, the bifurcation ratio $\left(R_{b}\right)$ was computed as the ratio of the number of first-order to second-order streams in a sample that covered about one-fourth of each drainage basin in the study region. First-order streams were selected as those shown to have no tributaries, and secondorder streams were selected as those shown to have two or more firstorder tributaries on State Highway Commission maps with a scale of one-half inch to the mile.

\section{MEAN FLOW DISTANCE}

For each sample basin in the Central region, a measure of the average distance, in miles, that a particle of water must travel to leave the drainage area as streamflow was available from previous studies. This mean flow distance $\left(L_{c a}\right)$ had been computed by methods described by Busby and Benson (1960) using information from 1:250,000-scale maps and $30-40$ sample points. 


\section{VALLEY WIDTH}

For all sample basins in the Central region only, the width of the river valley $\left(W_{v}\right)$, in miles, was determined from automobile odometer readings along the highway crossing the valley nearest the gaging site.

\section{MEAN ANNUAL PRECIPITATION}

Mean annual precipitation $(P)$ is a measure of the amount of water supplied to a drainage basin and of the potential runoff. It is a simple and comprehensive index that has proved useful in many previous studies. The methods used for determining mean annual precipitation differed among the four study regions.

For each sample drainage basin in the Southern and Western regions, mean annual precipitation, in inches, was determined from the isohyetal maps shown in figures 6 and 7. Values determined for the Southern region were reduced by 40 inches for use in the regression analysis.

For the Central region, mean annual precipitation for each basin was computed from U.S. Weather Bureau precipitation records by use of Thiessen polygons.

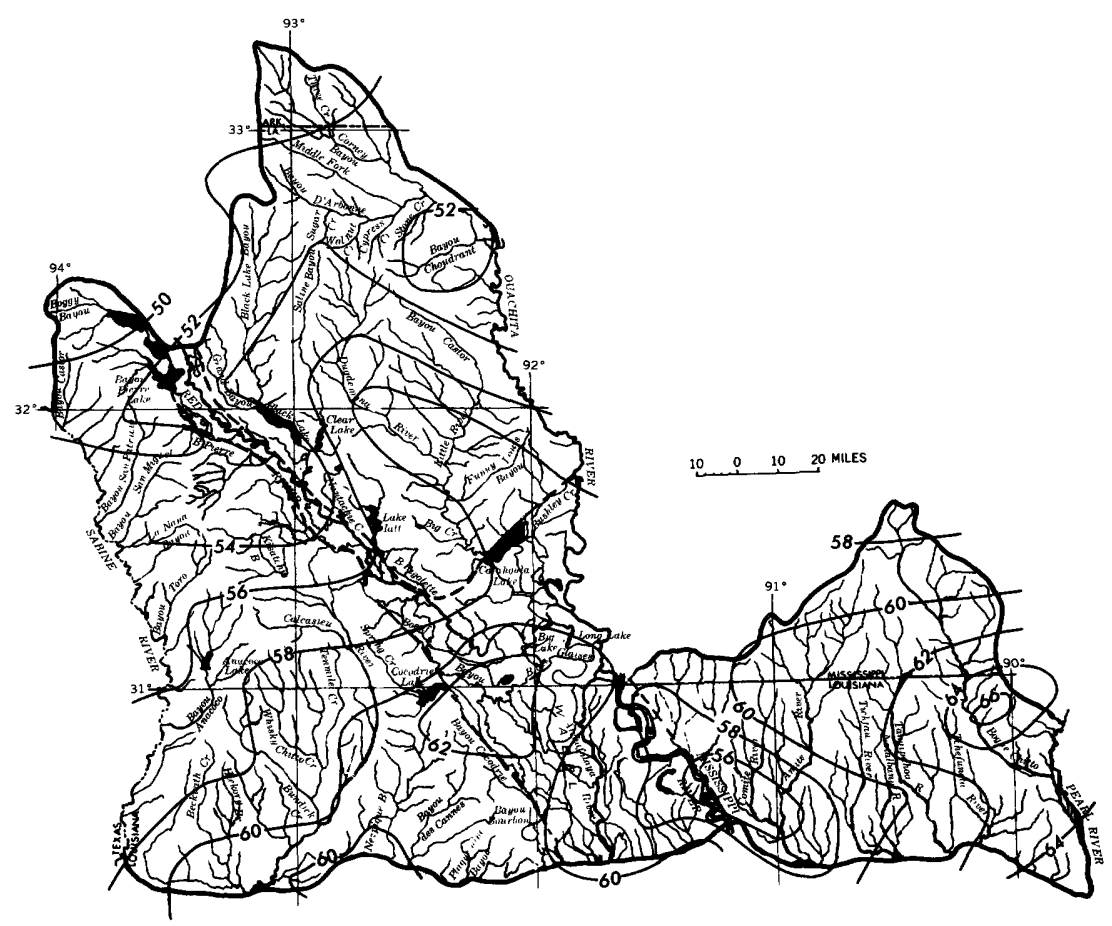

FIgURE 6.-Isohyetal map of mean annual precipitation in Southern region. 


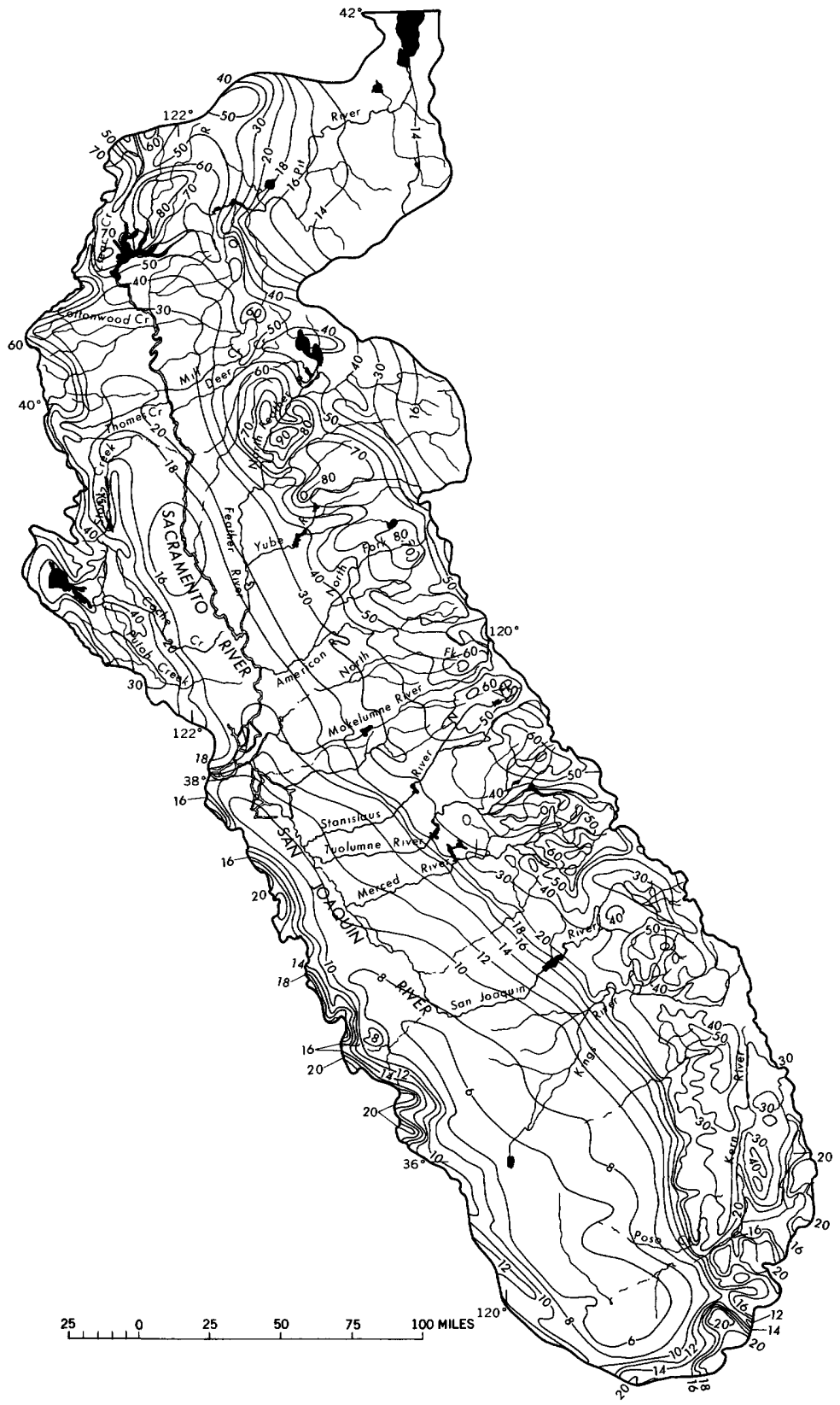

FTGURE 7.-Isohyetal map of mean annual precipitation in Western region. 
For drainage basins in the Coastal Plain and Piedmont geologic provinces of the Potomac River region, mean annual precipitation was determined from an isohyetal map (part of fig. 8 east of dotted line); but for basins in the remainder of this study region, it was determined from an elevation-precipitation relation and an anomaly map determined as described by Dawdy and Langbein (1960). Figure 8 shows the isohyetal and precipitation anomaly map of the Potomac River basin. For the part of the study region lying west of the dotted line the mean annual precipitation $(P)$ was computed as:

$$
P=9.28 E^{.69} K_{1}+30
$$

where $E$ is average basin elevation, in 1,000 feet above mean sea level, and $K$ is the areal average basin anomaly determined from figure 8 .

For each sample basin lying west of the dotted line in figure 8, the value of $P$ was obtained by (1) locating 20 or more random points in the basin with the aid of a grid laid over a basin map, (2) determining $E$ and $K_{1}$ for each random point, (3) computing $P$ for each point, and (4) averaging the 20 or more point values.

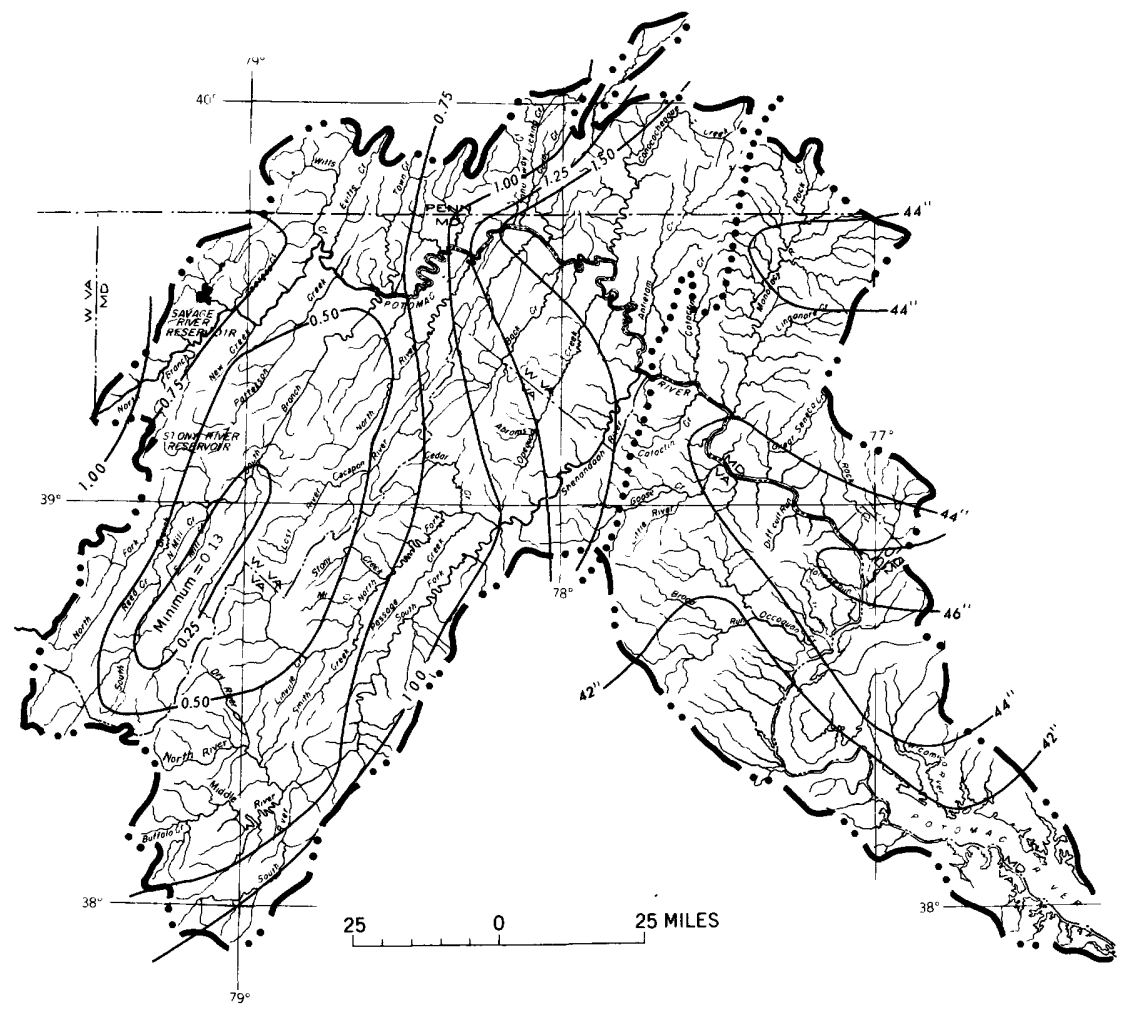

Figure 8.-Isohyetal and precipitation anomaly map of mean annual precipitation in Potomac River basin. 


\section{MEAN MONTHLY PREGIPITATION}

Because monthly streamflow characteristics were being generalized, in the first study (Eastern region) it was deemed advisable to evaluate the areal variations of monthly precipitation within the region. To do this, the proportion of mean annual precipitation that occurred in each calendar month was computed for each of the 96 precipitation stations in or near the basin. These values were then plotted on a separate map for each calendar month. No regional patterns of differences in proportions were apparent in the Potomac River basin, and it was concluded that monthly precipitation varied as a uniform proportion of annual precipitation throughout the basin. For example, all parts of the basin receive an average of 5.5 percent of the annual precipitation in February and an average of 10.0 percent of the annual precipitation in August. Because of this uniform areal distribution, any differences between streamflows from individual drainage areas can be explained as well by annual precipitation indices as by monthly precipitation indices.

Although no detailed studies were made of the areal variations of monthly precipitation in the Western, Central, and Southern regions, an inspection of precipitation records indicated that in those regions a similar conclusion would be reached. Therefore, no monthly mean precipitation indices were evaluated.

\section{SNOW}

Snow influences streamflow by temporary storage of precipitation. An index of snow might be expected, therefore, to provide a useful variable for describing the streamflow differences between drainage basins. Except for the Gulf Coast region, a snow index $(S n)$ was evaluated for each sample basin.

In the Potomac River basin the snow index was an estimate of the mean annual snowfall. It was evaluated from a snowfall-elevation relation and anomaly map as described by Dawdy and Langbein (1960). The snowfall-elevation-anomaly relation was developed from 96 precipitation station records, had a standard error of 10 percent, and was determined as:

$$
S n=18.0 E^{\cdot 70} K_{2}+10,
$$

where $S n$ is mean annual snowfall, in inches;

$E$ is elevation, in 1,000 feet above mean sea level ; and

$K_{2}$ is an anomaly value determined from the map in figure 9. 


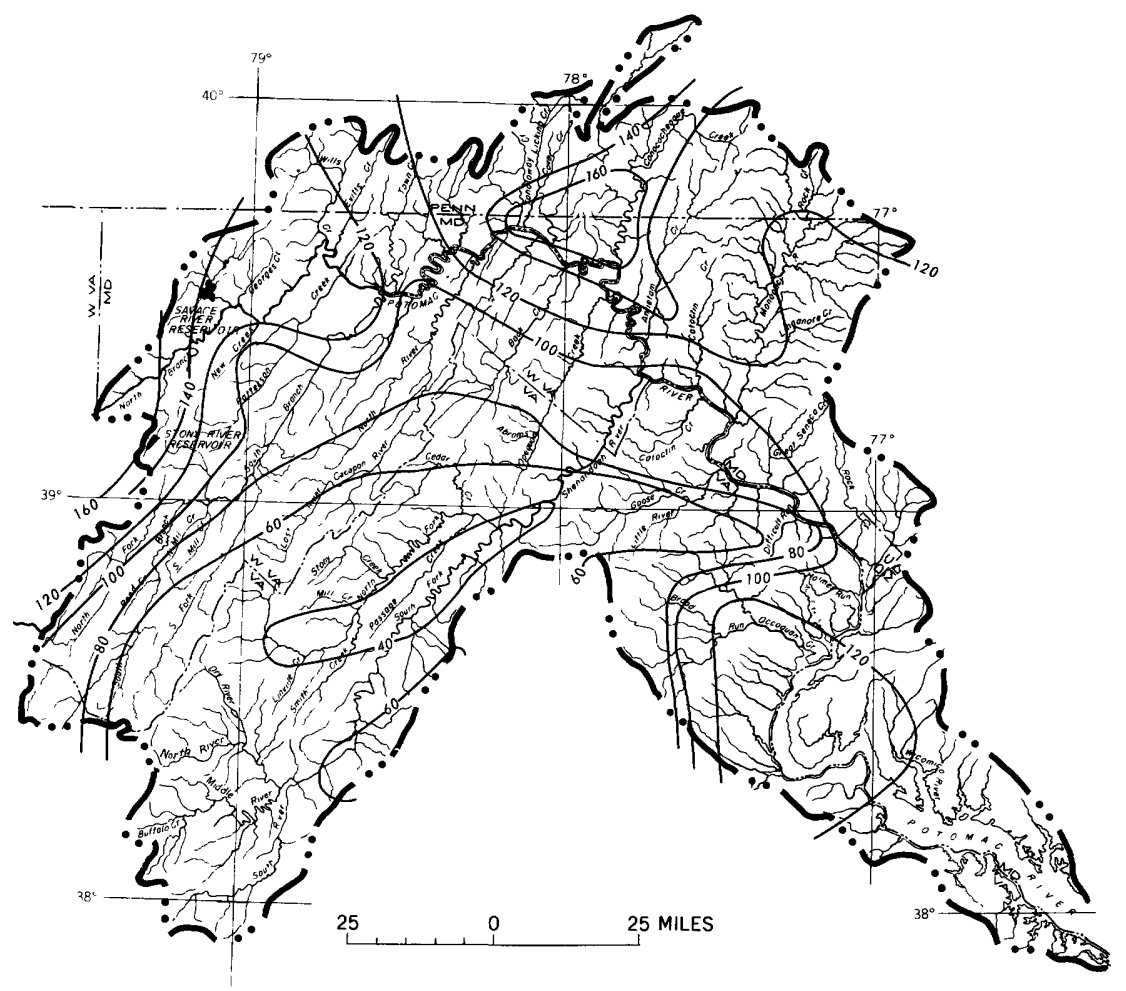

Figure 9.- Snow anomaly map of the Potomac River basin.

For each sample basin the average value of $S n$ was obtained by (1) locating 20 or more random points with the aid of a grid laid over a basin map, (2) determining $E$ and $K_{2}$ for each random point, (3) computing $S n$ for each point, and (4) averaging the 20 or more values to estimate the $S n$ for the basin.

In the Central region, average annual snowfall, in inches, was estimated for each sample basin directly from an available map (Flora, 1948), shown in figure 10.

The snow index used in the Western region was an estimate of the average water content, in inches, of the April 1 snowpack. Based upon published snowpack information (California Dept. Water Resources, 1965), the average relation between elevation and snowpack water content was defined for each of seven areas. Defined relations and the areas to which they apply are shown in figures 11 and 12. To define the average April 1 snowpack water content, hypsometric curves showing the area-elevation distribution were prepared for each sample basin. Data for defining these relations was available from the determination of average basin elevation $(E)$. The average eleva- 


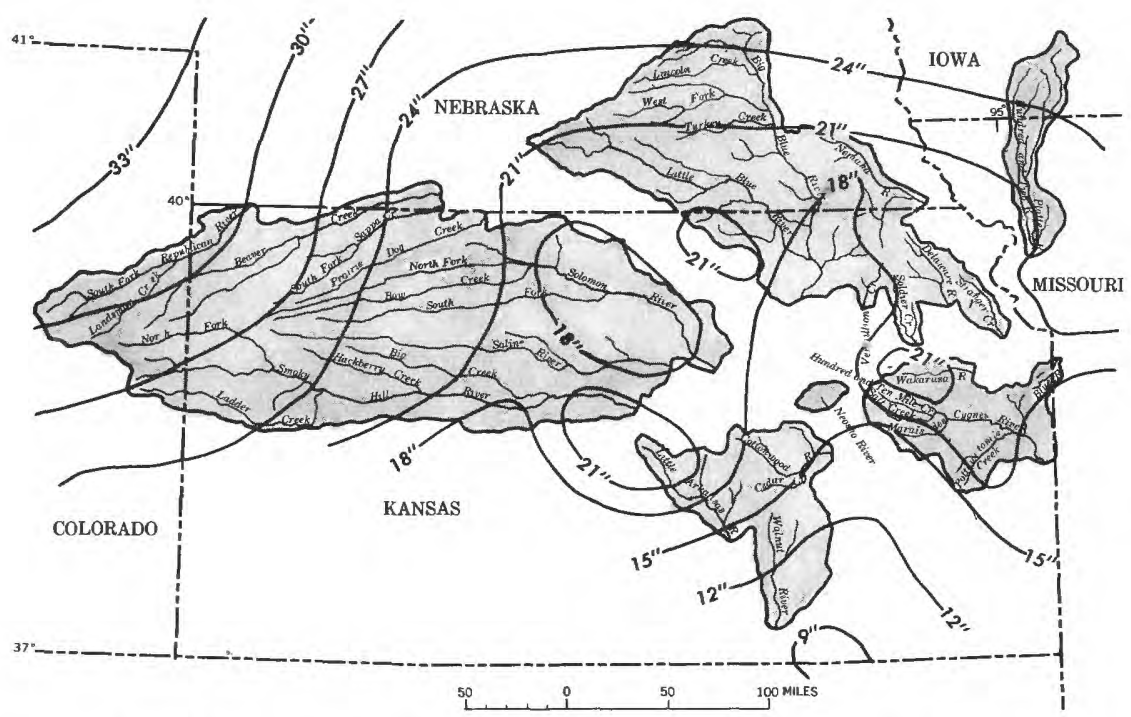

Frgure 10.-Average annual snowfall in the Central region. After Flora (1948).

tion for each 10-percent increment of area was determined from the hypsoemtric curves, and an estimate of water content for each of the 10 incremented areas was determined from the appropriate curves in figure 11. Averaging the 10 water contents provided an estimate of the basin average snowpack water content. To avoid the use of zero for some basins, all April 1 snowpack water contents were increased by 1.0 inch for use as $S n$ in the regression analysis.

\section{PRECIPITATION INTENSITY}

Many investigations (Benson, 1962; Chow, 1962; Linsley and others, 1949, p. 575) have found precipitation intensity to be a useful variable for explaining basin-to-basin variation in flood flows. On the basis of these previous investigations, precipitation intensity indices were evaluated for each basin used in this study.

Two of the precipitation-intensity indices selected were the maximum 24-hour precipitation expected to be exceeded on an average of once each 2 years $\left(I_{24,2}\right)$ and the maximum 24 -hour precipitation expected to be exceeded on an average of once each 100 years $\left(I_{24,100}\right)$ Values of these indices, in inches, were determined directly from U.S. Weather Bureau publications $(1958,1961)$ for all drainage areas in each study region.

Additional precipitation-intensity indices were investigated. Unithydrograph studies and flood-routing theory show that the most 


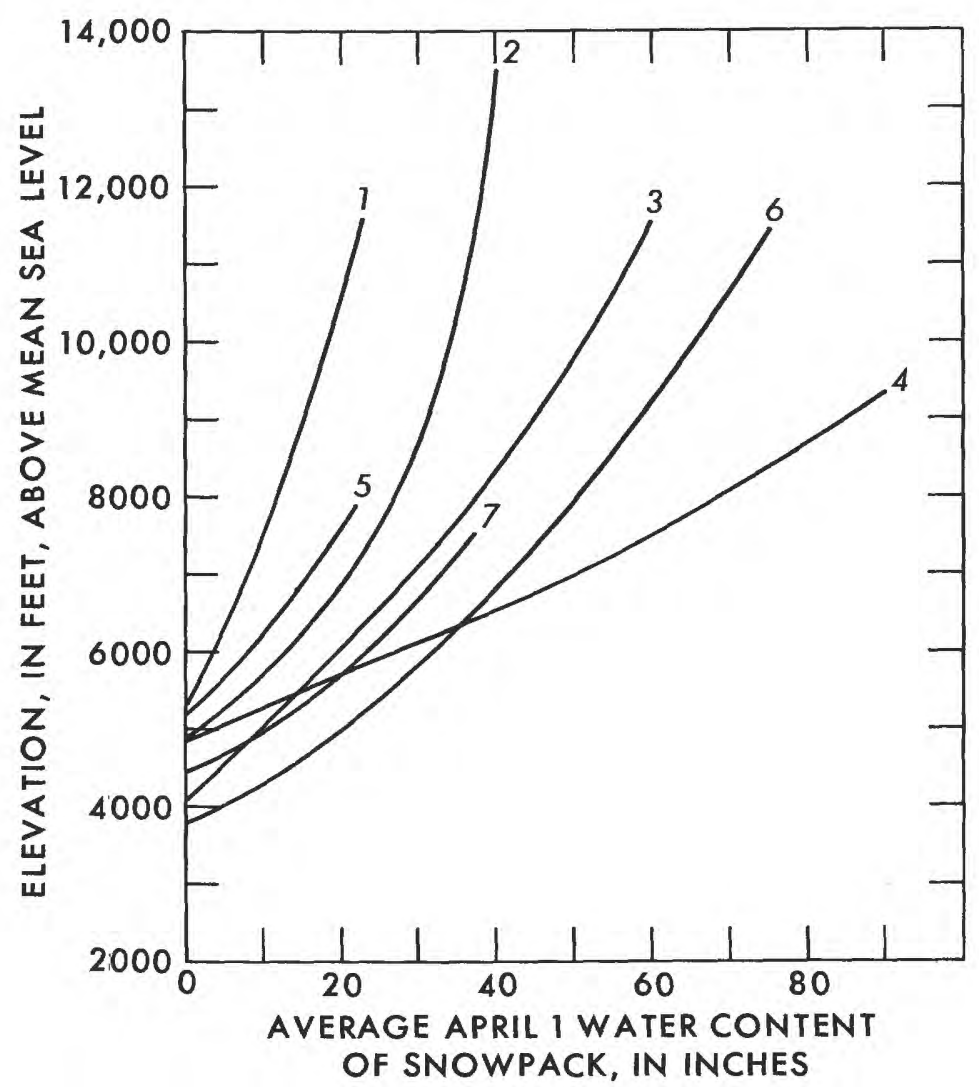

Figure 11.-Relation of average water content of the Aprll I snowpack to elevation for subregions of the Western region.

effective storm-rainfall duration varies with basin characteristics. To account partly for the effects of basin characteristics on the optimum storm duration, an empirical method of selecting optimum storm duration was tried in the Potomac River basin study. With this method the optimum storm duration, in hours $(h)$, was estimated as one-fifth the value of the drainage area, or $h=0.2 A$. For each sample drainage basin in the Potomac River basin, six indices of $h$-hour storm precipitation were evaluated directly from a U. S. Weather Bureau publication (1958). These indices were the maximum $h$-hour precipitation, in inches, that is expected to be exceeded on an average of once each $2,5,10,25,50$, and 100 years, respectively.

During analysis of the Potomac River basin relations, $h$-hour precipitation indices were found to be highly related amongst themselves and 


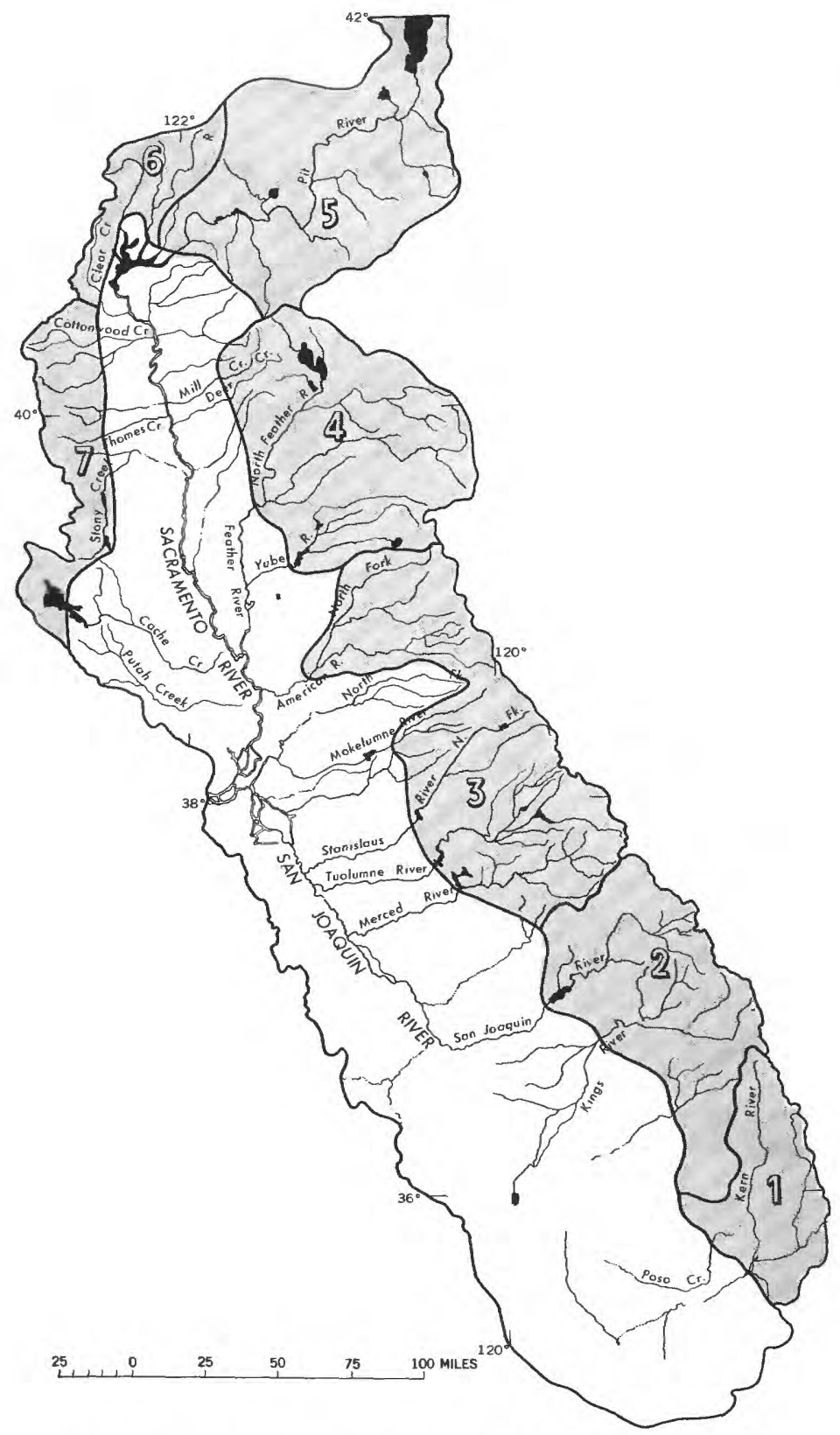

Figure 12.-Snowpack subregions for the Western region.

to size of drainage area. This indicated that any streamflow variations that might be explained by the $h$-hour precipitation indices could be explained almost as well by drainage area; therefore, $h$-hour precipi- 
tation indices were dropped from the analysis. These indices of precipitation intensity were omitted from consideration in the Western, Central, and Southern region studies.

\section{AVERAGE ANNUAL EVAPORATION}

An index of average annual lake and reservoir evaporation $(E v)$, in inches, was evaluated for all sample basins in the Central region. Information to evaluate the index was provided by the Kansas Water Resources Board.

\section{THUNDERSTORM DAYS}

In his study of floods in the Southwestern United States, Benson (1964) found that the average number of thunderstorm days per year explained a part of the basin-to-basin variation in flood discharge. The average number of thunderstorm days was estimated for each sample drairage basin in the Potomac River basin from a U.S. Weather Bureau publication (1952). However, in the Potomac River basin the variation of thunderstorm days among basins was found to be small and was not included in the regression analysis. Thunderstorm days was not evaluated for use as a basin characteristic in the other study region.

\section{TEMPERATURE}

Temperature may affect streamflow by changing storage through accumulation or melting of snow and also by influencing transpiration and evaporation losses. In his study of New England floods, Benson (1962) found January mean temperature a significant variable for explaining basin-to-basin variation in flood peaks.

Two temperature indices were evaluated for each sample drainage basin in the Potomac River and Central regions. One index was the mean of the minimum daily January temperatures $\left(t_{1}\right)$, and the other was the mean of the maximum daily July temperatures $\left(t_{7}\right)$. These indices were evaluated from generalized temperature maps published in the "Climates of the States" series of the U.S. Weather Bureau publications (1959-61). Inspection of the temperature values indicated very little basin-to-basin variation in the Potomac River basin; therefore these two indices were not included in that regression analysis.

\section{ANALYTICAL METHODS}

Statistical multiple-regression analysis was used to develop separately for each study region the relations between streamflow characteristics (dependent variables) and drainage-basin characteristics (independent variables). Briefly, multiple regression provides a mathematical equation of the relation between a single dependent 
variable and the independent variables. It also provides a measure of the accuracy of the defined relation (known as the standard error of estimate) and measures of the usefulness of each independent variable in the relation.

The standard error of estimate is a range of error such that the value estimated by the regression equation is within this range at about two out of three sites, and is within twice this range at about 19 out of 20 sites.

The usefulness of each independent variable to any relation is judged both on the basis of its statistical significance and on the basis of the reduction in the standard error that is brought about by including the variable. Those independent variables that had a 95-percent probability of effectiveness were classed as significant to the equation. and those variables that had a 99-percent probability of effectiveness were classed as highly significant.

Past experience in many hydrologic studies has shown that streamflow discharges are linearly related to most basin characteristics if the logarithms of each are used. Several graphic plots of the logarithms of streamflow characteristics versus logarithms of basin characteristics indicated general applicability of the linear regression model for logarithms of the variables. Therefore, all streamflow and basin characteristics were transformed into logarithms before calculations were performed.

A high-speed digital computer performed the voluminous calculations required for regression analysis. The procedure involved entering into the computer, for each of the sample basins in a study region, a single streamflow variable along with several selected basin variables that might possibly explain the basin-to-basin streamflow variation. The computer calculated the regression equation, standard error of estimate, and effectiveness of each independent variable. Automatically then, the computer repeated the calculations omitting the least effective basin variable. This process of recalculation, omitting the least effective basin variable, was repeated until only the one most effective independent variable remained. After the relations for a given streamflow characteristic had all been evaluated, the entire computation process was repeated using another streamflow characteristic as the dependent variable along with a selected set of basin characteristics as independent variables.

The equation with the greatest number of independent variables, all of which are significant, would ordinarily be used for purposes of prediction unless other considerations modify the choice. If an independent variable is significant, but has only a small effect on the standard error, it might be omitted. If a variable is not significant at 
the chosen level of significance, but is significant in other equations, for similar streamflow characteristics, it might be included for consistency with other equations.

One of the practical requisites in multiple-regression analysis is that the various independent variables (in this analysis the basin characteristics) not be highly related amongst themselves. Violation of this criterion can lead to unstable values for the regression coefficients and to difficulties in interpreting the effectiveness of independent variables included in the equation. Although a set of topographic and climatic variables that are entirely independent of each other would be preferable, this is not possible because nearly all natural topographic and climatic variables exhibit some degree of interdependence. To investigate the amount of nonindependence, a simple correlation matrix of the evaluated basin characteristics was obtained for each study region, and the results are given in tables 2-5. In these tables a value of 1.00 means perfect correlation, a value of 0 , complete independence, and a value of -1.00 , perfect inverse correlation.

In the Potomac River basin, high correlation values between drainage area and all classes of $h$-hour precipitation intensities (which had been computed on the basis of drainage area), indicated that only one of the variables should be used; therefore, all $h$-hour precipitation intensities were omitted from further consideration. Similarly, in the California study, length $(L)$, percentage of area above 5,000 feet $(A e)$, and 24-hour precipitation intensity with a 100-year recurrence interval $\left(I_{24},{ }_{100}\right)$ were omitted after several trial computations indicated that better results would be obtained by using the highly related variables elevation $(E)$, snow $(S n)$, and 24-hour precipitation intensity with a 2-year recurrence interval $\left(I_{24,2}\right)$.

Several other variables in each study region showed relatively high interdependence. For example, highly interrelated in the Potomac River basin were area and slope, area and length, elevation and snow, elevation and forest, and elevation and soil storage. Although all these variables were tested in the analysis, their effects on computed relations were closely inspected. Where the combination of interdependent variables appeared to produce unstable regression coefficients, or where the computed equations indicated results contrary to hydrologic reasoning, one of the interrelated variables was arbitarily selected for use, the other dropped from consideration, and the equations recomputed. The process, therefore, involved some trial-and-error procedures to select the most useful combinations of variables. 


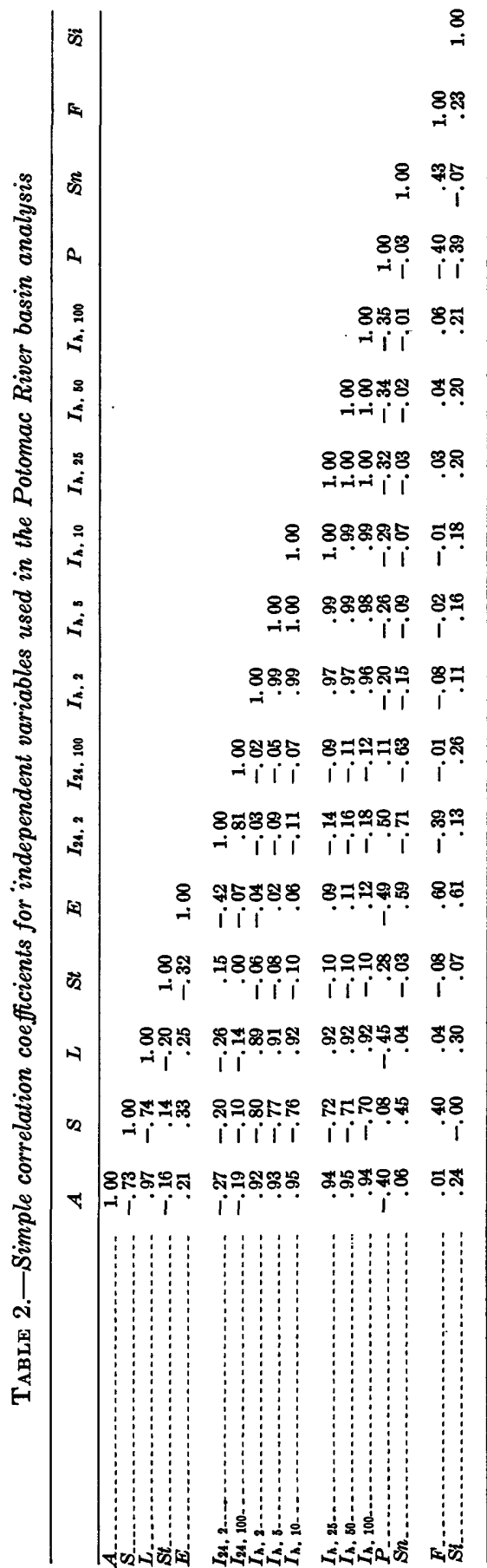




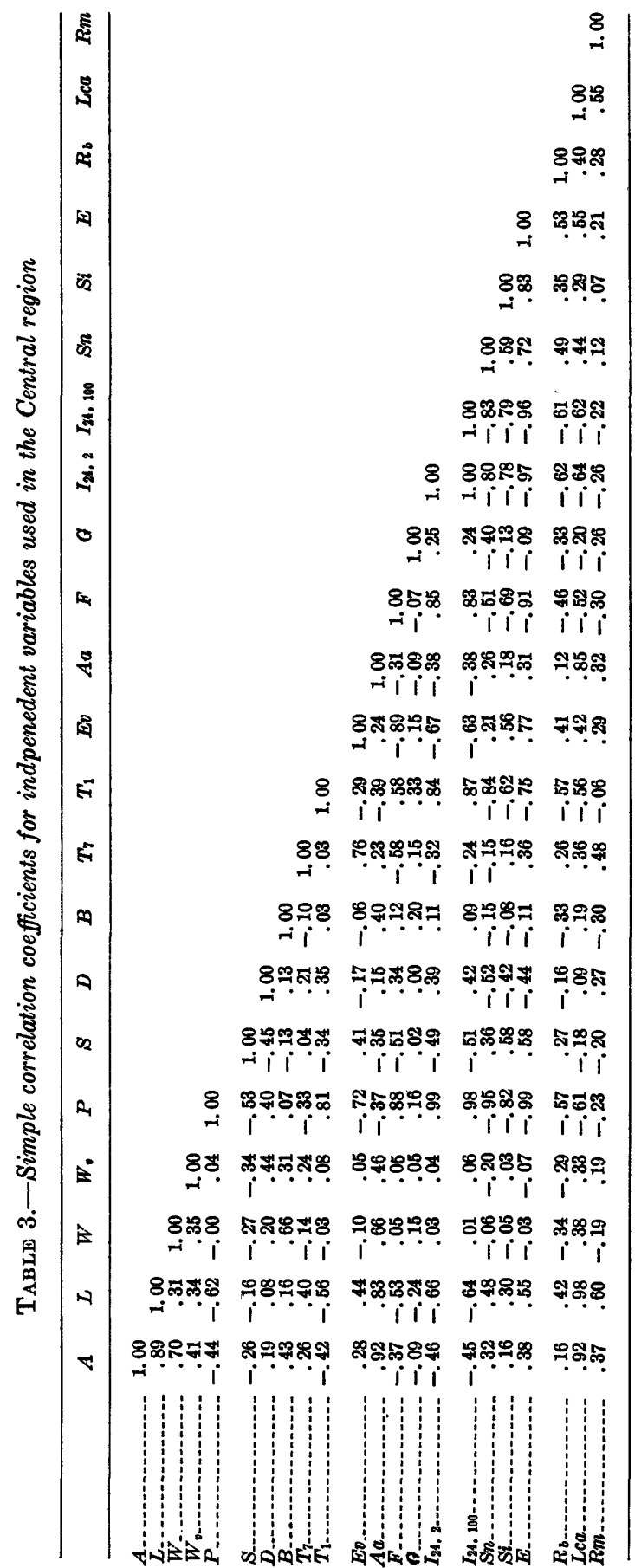


TABLE 4.-Simple correlation coefficients for independent variables used in the Southern region analysis

\begin{tabular}{|c|c|c|c|c|c|c|c|c|c|c|}
\hline & $A$ & $S$ & $L$ & st & $\boldsymbol{E}$ & $F$ & $I_{24,2}$ & $I_{24,100}$ & $P$ & $S i$ \\
\hline St & $\begin{array}{r}1.00 \\
-.58 \\
.88 \\
.15 \\
.04\end{array}$ & $\begin{array}{r}1.00 \\
=.54 \\
-. .17 \\
.56\end{array}$ & $\begin{array}{r}1.00 \\
-.04 \\
.05\end{array}$ & $\begin{array}{r}1.00 \\
-.22\end{array}$ & 1.00 & & & & & \\
\hline $\begin{array}{l}F \\
I_{24}, 22 \\
I_{24}, 100\end{array}$ & $\begin{array}{r}.18 \\
-.08 \\
-.08\end{array}$ & $\begin{array}{r}.46 \\
-.22 \\
-.16\end{array}$ & $\begin{array}{r}.12 \\
-.02 \\
-.10\end{array}$ & $\begin{array}{r}.06 \\
.16 \\
.10\end{array}$ & $\begin{array}{r}.58 \\
-.53 \\
-.47\end{array}$ & $\begin{array}{r}1.00 \\
-.51 \\
-.45\end{array}$ & $\begin{array}{r}1.00 \\
.91\end{array}$ & 1.00 & & \\
\hline Si & .20 & $\begin{array}{r}-.24 \\
.15\end{array}$ & $\begin{array}{l}.26 \\
.14\end{array}$ & $\begin{array}{r}.06 \\
-.04\end{array}$ & $\begin{array}{r}-.17 \\
.19\end{array}$ & $\begin{array}{r}-.23 \\
.42\end{array}$ & $\begin{array}{r}.71 \\
-.33\end{array}$ & $\begin{array}{r}.61 \\
-.37\end{array}$ & $\begin{array}{r}1.00 \\
-.04\end{array}$ & 1.0 \\
\hline
\end{tabular}

TABLE 5.-Simple correlation coefficients for independent variables used in the Western region analysis

\begin{tabular}{|c|c|c|c|c|c|c|c|c|c|c|c|c|}
\hline & $A$ & $s$ & $L$ & $S t$ & $E$ & $I_{24,2}$ & $I_{24.100}$ & $P$ & $F$ & $S i$ & $S n$ & $A c$ \\
\hline $\begin{array}{l}A \\
S \\
S \\
S \\
S E \\
E\end{array}$ & $\begin{array}{r}1.00 \\
-.24 \\
-.89 \\
-.01 \\
.11\end{array}$ & $\begin{array}{r}1.00 \\
-.35 \\
. .27 \\
.74\end{array}$ & $\begin{array}{r}1.00 \\
=.21 \\
-.13\end{array}$ & $\begin{array}{r}1.00 \\
.41\end{array}$ & 1.00 & & & & & & & \\
\hline 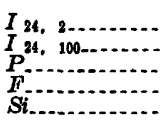 & $\begin{array}{r}.05 \\
.11 \\
-.07 \\
.09 \\
.06\end{array}$ & $\begin{array}{r}.25 \\
.38 \\
.43 \\
-.22 \\
-.52\end{array}$ & $\begin{array}{r}.12 \\
.12 \\
-.08 \\
.14 \\
.28\end{array}$ & $\begin{array}{r}-.39 \\
-.26 \\
.10 \\
-.56 \\
-.72\end{array}$ & $\begin{array}{r}.33 \\
.49 \\
.61 \\
-.35 \\
-.61\end{array}$ & $\begin{array}{l}1.00 \\
.93 \\
.64 \\
.64 \\
.18\end{array}$ & $\begin{array}{r}1.00 \\
.66 \\
.61 \\
.05\end{array}$ & $\begin{array}{r}1.00 \\
-.43 \\
-.31\end{array}$ & $\begin{array}{r}1.00 \\
.30\end{array}$ & 1.00 & & \\
\hline $\begin{array}{l}S n_{\ldots} \\
A e_{\ldots} \ldots \ldots\end{array}$ & .10 & .62 & $\begin{array}{l}-.14 \\
-.13\end{array}$ & $\begin{array}{l}.52 \\
.43\end{array}$ & $\begin{array}{l}.89 \\
.88\end{array}$ & .19 & $\begin{array}{l}.36 \\
.39\end{array}$ & $\begin{array}{l}.55 \\
.53\end{array}$ & .09 & $\begin{array}{l}-.68 \\
-.64\end{array}$ & $\begin{array}{r}1.00 \\
.96\end{array}$ & 1.00 \\
\hline
\end{tabular}

\section{RESULTS}

Tables 6-9 summarize the results of the multiple-regression analyses. These analyses defined mathematical equations of the form:

$$
\log Y=\log a+b_{1} \log X_{1}+b_{2} \log X_{2} \ldots+b_{n} \log X_{n},
$$

or its equivalent form:

where

$$
Y=a X_{1}^{b_{1}} X_{2}^{b_{2}} \ldots X_{n}^{b_{n}}
$$

$Y=\mathrm{a}$ streamflow characteristic,

$X_{1}$ to $X_{n}=$ basin characteristics,

$a=$ the regression constant, and

$b_{1}$ to $b_{n}=$ regression coefficients.

In the tables the first column indicates the streamflow characteristic studied. The next set of columns gives the computed regression constant and regression coefficients for that streamflow characteristic. The last two columns give, respectively, the standard error of estimate in logarithmic units and in approximate equivalent percent. 
TABLE 6.-Summary of Eastern region regression relations:

$\mathrm{Y}=\mathrm{a} \mathrm{A} \mathrm{b}_{1} \mathrm{Sb}_{2} \mathrm{Lb}_{3} \mathrm{Stb}_{4} \mathrm{~Eb}_{5} \mathrm{I}_{24,2} \mathrm{~b}_{6} \mathrm{~Pb}_{7} \mathrm{Sn}_{8} \mathrm{~b}_{9} \mathrm{Fb}_{9} \mathrm{Sib}_{10}$

[All regression coefficients are statistically significant at the 5 percent level, except those preceded by $d$ ]

\begin{tabular}{|c|c|c|c|c|c|c|c|c|c|c|c|c|c|}
\hline \multirow{2}{*}{$\begin{array}{l}\text { Flow } \\
\text { Index } \\
Y\end{array}$} & \multirow{2}{*}{$\begin{array}{c}\text { Re jression } \\
\text { Constant } \\
a^{*}\end{array}$} & \multicolumn{10}{|c|}{ Regression Coefficients for } & \multicolumn{2}{|c|}{$\begin{array}{l}\text { Standard } \\
\text { Frror }\end{array}$} \\
\hline & & A & $s$ & L & $\mathrm{st}$ & $\mathrm{E}$ & $I_{24,2}$ & $P$ & $\mathrm{Sn}$ & F & Si & Er & क \\
\hline$P_{50}$ & $\begin{array}{l}- \\
600 \\
63.9 \\
187 \\
228 \\
134\end{array}$ & $\begin{array}{r}- \\
0.72 \\
.90 \\
1.09 \\
1.09 \\
.73\end{array}$ & $\begin{array}{c}- \\
- \\
0.42 \\
.87 \\
.90 \\
.96\end{array}$ & $\begin{array}{l}- \\
- \\
- \\
- \\
0.67\end{array}$ & $\begin{array}{c}- \\
- \\
- \\
- \\
-1.08 \\
-.93\end{array}$ & $\begin{array}{l}- \\
\overline{-} \\
- \\
- \\
-\end{array}$ & $\begin{array}{l}- \\
- \\
- \\
- \\
-\end{array}$ & $\begin{array}{l}- \\
- \\
- \\
-\end{array}$ & $\begin{array}{c}- \\
- \\
- \\
-1.05 \\
-1.11 \\
-1.16\end{array}$ & $\begin{array}{l}- \\
\overline{-} \\
\overline{-} \\
\overline{-}\end{array}$ & $\begin{array}{l}- \\
- \\
- \\
- \\
-\end{array}$ & $\begin{array}{r}0.542 \\
.246 \\
.223 \\
.194 \\
.176 \\
.167\end{array}$ & $\begin{array}{l}160 \\
59.7 \\
53.4 \\
46.1 \\
41.6 \\
39.2\end{array}$ \\
\hline$P_{25}$ & $\begin{array}{c}381^{-} \\
60.5 \\
124^{-} \\
143\end{array}$ & $\begin{array}{r}- \\
.74 \\
.88 \\
1.01 \\
1.01\end{array}$ & $\begin{array}{l}- \\
- \\
.35 \\
.64 \\
.67\end{array}$ & $\begin{array}{l}- \\
- \\
- \\
-\end{array}$ & $\begin{array}{c}- \\
- \\
- \\
- \\
-.78\end{array}$ & $\begin{array}{l}- \\
- \\
- \\
-\end{array}$ & $\begin{array}{l}- \\
- \\
- \\
-\end{array}$ & - & $\begin{array}{c}- \\
- \\
- \\
-.70 \\
-.74\end{array}$ & $\begin{array}{l}- \\
- \\
- \\
-\end{array}$ & $\begin{array}{l}- \\
- \\
- \\
-\end{array}$ & $\begin{array}{l}.530 \\
.189 \\
.168 \\
.152 \\
.141\end{array}$ & $\begin{array}{l}155 \\
44.9 \\
39.6 \\
35.8 \\
33.0\end{array}$ \\
\hline$P_{10}$ & $\begin{array}{c}{ }^{-} \\
204^{-} \\
55.1 \\
7.16 \\
3.94 \\
2.94\end{array}$ & $\begin{array}{l}- \\
.76 \\
.87 \\
.94 \\
.89 \\
.89\end{array}$ & $\begin{array}{l}- \\
- \\
.25 \\
.37 \\
.26 \\
.27\end{array}$ & $\begin{array}{l}- \\
- \\
- \\
- \\
-\end{array}$ & $\begin{array}{l}- \\
- \\
- \\
- \\
- \\
-.50\end{array}$ & $\begin{array}{l}- \\
- \\
- \\
-\end{array}$ & $\begin{array}{c}- \\
- \\
- \\
1.20 \\
1.28 \\
1.47\end{array}$ & $\begin{array}{l}- \\
- \\
- \\
-\end{array}$ & $\begin{array}{l}- \\
- \\
- \\
- \\
-\end{array}$ & $\begin{array}{l}- \\
- \\
- \\
0.28 \\
.30\end{array}$ & $\begin{array}{l}- \\
- \\
- \\
- \\
-\end{array}$ & $\begin{array}{l}.530 \\
.134 \\
.119 \\
.113 \\
.106 \\
.099\end{array}$ & $\begin{array}{r}155 \\
31.4 \\
27.8 \\
26.2 \\
24.6 \\
23.0\end{array}$ \\
\hline$P_{5}$ & $\begin{array}{c}129 \\
35.6 \\
12.8 \\
4.28\end{array}$ & $\begin{array}{l}- \\
.78 \\
.78 \\
.79 \\
.88\end{array}$ & $\begin{array}{l}- \\
- \\
- \\
- \\
.18\end{array}$ & $\begin{array}{l}- \\
- \\
- \\
-\end{array}$ & $\begin{array}{l}- \\
- \\
- \\
-\end{array}$ & $\begin{array}{l}- \\
- \\
-\end{array}$ & $\begin{array}{c}- \\
- \\
- \\
\text { d. } \\
1.15\end{array}$ & $\begin{array}{l}- \\
\text { - } \\
\text { - }\end{array}$ & $\begin{array}{l}- \\
- \\
- \\
-\end{array}$ & $\begin{array}{l}- \\
. \\
.32 \\
.38 \\
.28\end{array}$ & $\begin{array}{l}- \\
- \\
- \\
-\end{array}$ & $\begin{array}{l}.536 \\
.111 \\
.094 \\
.092 \\
.086\end{array}$ & $\begin{array}{r}157 \\
25.9 \\
21.8 \\
21.4 \\
19.9\end{array}$ \\
\hline$P_{2}$ & $\begin{array}{c}- \\
65.1 \\
29.6 \\
31.8\end{array}$ & $\begin{array}{r}. \\
.80 \\
.80 \\
1.04\end{array}$ & $\begin{array}{l}- \\
- \\
-\end{array}$ & $\begin{array}{c}- \\
- \\
- \\
-.42\end{array}$ & $\begin{array}{l}- \\
- \\
-\end{array}$ & $\begin{array}{l}- \\
- \\
-\end{array}$ & $\begin{array}{l}- \\
- \\
-\end{array}$ & - & $\begin{array}{l}- \\
- \\
-\end{array}$ & $\begin{array}{l}- \\
- \\
.20 \\
.23\end{array}$ & $\begin{array}{l}- \\
- \\
-\end{array}$ & $\begin{array}{l}.547 \\
.097 \\
.091 \\
.083\end{array}$ & $\begin{array}{r}162 \\
22.5 \\
21.1 \\
19.2\end{array}$ \\
\hline$P_{1.2}$ & $\begin{array}{c}- \\
34.7 \\
45.4 \\
22.6 \\
43.5\end{array}$ & $\begin{array}{r}- \\
.81 \\
1.13 \\
1.16 \\
1.11\end{array}$ & $\begin{array}{l}- \\
\overline{-} \\
\overline{-} \\
-\end{array}$ & $\begin{array}{c}- \\
- \\
-.56 \\
-.61 \\
-.50\end{array}$ & $\begin{array}{l}- \\
- \\
- \\
-\end{array}$ & $\begin{array}{l}- \\
- \\
-\end{array}$ & $\begin{array}{l}- \\
- \\
- \\
-\end{array}$ & - & $\begin{array}{l}- \\
- \\
- \\
-\end{array}$ & $\begin{array}{l}- \\
- \\
- \\
.18 \\
.22\end{array}$ & $\begin{array}{l}- \\
- \\
- \\
- \\
- \\
-\end{array}$ & $\begin{array}{l}.557 \\
.118 \\
.107 \\
.102 \\
.098\end{array}$ & $\begin{array}{l}166 \\
27.4 \\
24.8 \\
23.8 \\
22.6\end{array}$ \\
\hline$v_{3,50}$ & $\begin{array}{c}- \\
33.0 \\
9.81\end{array}$ & $\begin{array}{l}- \\
1.02 \\
1.11\end{array}$ & $\begin{array}{l}- \\
- \\
.23\end{array}$ & $\begin{array}{l}- \\
-\end{array}$ & - & - & $\begin{array}{l}- \\
-\end{array}$ & - & - & - & - & $\begin{array}{r}.708 \\
.181 \\
.173\end{array}$ & $\begin{array}{r}245 \\
42.8 \\
40.8\end{array}$ \\
\hline$v_{3,20}$ & $\begin{array}{c}26.3 \\
6.38\end{array}$ & $\begin{array}{l}- \\
1.00 \\
1.00\end{array}$ & $\begin{array}{l}- \\
-\end{array}$ & $\begin{array}{l}- \\
-\end{array}$ & - & - & $\begin{array}{l}- \\
-\end{array}$ & - & - & $\begin{array}{l}- \\
- \\
.35\end{array}$ & - & $\begin{array}{l}.685 \\
.144 \\
.129\end{array}$ & $\begin{array}{r}232 \\
33.6 \\
30.2\end{array}$ \\
\hline$v_{3,10}$ & $\begin{array}{c}- \\
21.6 \\
5.71 \\
1.80 \\
.628\end{array}$ & $\begin{array}{r}- \\
.98 \\
.98 \\
1.00 \\
1.08\end{array}$ & $\begin{array}{l}- \\
- \\
- \\
- \\
.18\end{array}$ & $\begin{array}{l}- \\
- \\
- \\
-\end{array}$ & $\begin{array}{l}- \\
- \\
- \\
-\end{array}$ & $\begin{array}{l}- \\
- \\
-\end{array}$ & $\begin{array}{c}- \\
- \\
- \\
\text { d. } 76 \\
1.21\end{array}$ & $\begin{array}{l}- \\
- \\
-\end{array}$ & $\begin{array}{l}- \\
- \\
- \\
-\end{array}$ & $\begin{array}{l}- \\
- \\
.33 \\
.40 \\
.30\end{array}$ & $\begin{array}{l}- \\
- \\
- \\
-\end{array}$ & $\begin{array}{l}.672 \\
.120 \\
.104 \\
.101 \\
.097\end{array}$ & $\begin{array}{r}225 \\
28.0 \\
24.2 \\
23.4 \\
22.5\end{array}$ \\
\hline$v_{3,2}$ & $\begin{array}{c}- \\
10.7 \\
3.67 \\
3.86\end{array}$ & $\begin{array}{r}- \\
.97 \\
.96 \\
1.14\end{array}$ & $\begin{array}{l}- \\
- \\
-\end{array}$ & $\begin{array}{l}- \\
- \\
- \\
- \\
-\end{array}$ & $\begin{array}{l}- \\
- \\
-\end{array}$ & - & $\begin{array}{l}- \\
- \\
-\end{array}$ & - & $\begin{array}{l}- \\
- \\
-\end{array}$ & $\begin{array}{l}- \\
- \\
.27 \\
.29\end{array}$ & $\begin{array}{l}- \\
- \\
-\end{array}$ & $\begin{array}{l}.656 \\
.095 \\
.081 \\
.077\end{array}$ & \begin{tabular}{|c}
216 \\
22.0 \\
18.8 \\
17.9
\end{tabular} \\
\hline$v_{7,50}$ & $\begin{array}{c}- \\
16.1 \\
3.22\end{array}$ & $\begin{array}{l}- \\
1.014 \\
1.04\end{array}$ & $\begin{array}{l}- \\
-\end{array}$ & - & I & : & $\begin{array}{l}- \\
-\end{array}$ & - & $\begin{array}{l}- \\
-\end{array}$ & $\begin{array}{l}- \\
- \\
.40\end{array}$ & - & $\begin{array}{l}.717 \\
.160 \\
.142\end{array}$ & $\begin{array}{l}251 \\
37.5 \\
33.3\end{array}$ \\
\hline$v_{7,20}$ & $\begin{array}{c}- \\
14.1 \\
3.50\end{array}$ & $\begin{array}{l}- \\
1.01 \\
1.01\end{array}$ & $\begin{array}{l}- \\
-\end{array}$ & - & $\begin{array}{l}- \\
- \\
-\end{array}$ & - & - & - & - & $\begin{array}{l}- \\
- \\
.35\end{array}$ & $\begin{array}{l}- \\
-\end{array}$ & $\begin{array}{l}.689 \\
.127 \\
.110\end{array}$ & $\begin{array}{l}234 \\
29.7 \\
25.6\end{array}$ \\
\hline
\end{tabular}


TABLE 6.-Summary of Eastern region regression relations: $\mathrm{Y}=\mathrm{a} \mathrm{A} \mathrm{A}_{1} \mathrm{Sb}_{2} \mathrm{Lb}_{3} \mathrm{St}_{4} \mathrm{E}^{\mathrm{b}} \mathrm{I}_{5} \mathrm{I}_{24,2}{ }_{6} \mathrm{~Pb}_{7} \mathrm{Sn}_{8} \mathrm{~F}^{\mathrm{b}_{9}} \mathrm{Si}^{\mathrm{b}}{ }_{10}$-Continued

\begin{tabular}{|c|c|c|c|c|c|c|c|c|c|c|c|c|c|}
\hline \multirow{2}{*}{$\begin{array}{l}\text { Flow } \\
\text { Index } \\
Y\end{array}$} & \multirow{2}{*}{$\begin{array}{c}\text { Regression } \\
\text { Constant } \\
\mathbf{a}^{*}\end{array}$} & \multicolumn{10}{|c|}{ Regression Coefficients for } & \multirow{2}{*}{\multicolumn{2}{|c|}{$\begin{array}{l}\text { Standard } \\
\text { Error }\end{array}$}} \\
\hline & & A & s & I. & st & E & $I_{24,2}$ & $P$ & Sn & $F$ & $\mathrm{Si}$ & & \\
\hline$v_{7,10}$ & $\frac{12.3}{3 \cdot 32}$ & $\begin{array}{r}- \\
0.99 \\
.99\end{array}$ & - & - & $\overline{-}$ & $\begin{array}{l}- \\
-\end{array}$ & - & $\overline{-}$ & - & $\begin{array}{c}- \\
0.33\end{array}$ & - & $\begin{array}{r}0.674 \\
.108 \\
.089\end{array}$ & $\begin{array}{l}225 \\
25.1 \\
20.8\end{array}$ \\
\hline$v_{7,2}$ & $\begin{array}{l}- \\
6.60 \\
2.46 \\
2.60\end{array}$ & $\begin{array}{r}. \\
.97 \\
.97 \\
1.17\end{array}$ & $\begin{array}{l}- \\
-\end{array}$ & $\begin{array}{c}- \\
- \\
-0.34\end{array}$ & 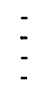 & $\overline{-}$ & $\begin{array}{l}- \\
-\end{array}$ & $\begin{array}{l}- \\
-\end{array}$ & $\begin{array}{l}- \\
-\end{array}$ & $\begin{array}{l}- \\
- \\
.25 \\
.27\end{array}$ & $\begin{array}{l}- \\
-\end{array}$ & $\begin{array}{l}.661 \\
.093 \\
.081 \\
.075\end{array}$ & $\begin{array}{l}219 \\
21.5 \\
18.7 \\
17.4\end{array}$ \\
\hline$D_{10}$ & $\begin{array}{l}- \\
2.30 \\
.503 \\
5.14(-3) \\
8.77(-4)\end{array}$ & $\begin{array}{l}- \\
.98 \\
.98 \\
1.00 \\
1.08\end{array}$ & $\begin{array}{l}= \\
= \\
0.15\end{array}$ & $\begin{array}{l}- \\
-\end{array}$ & $\begin{array}{l}- \\
- \\
-\end{array}$ & $\begin{array}{l}- \\
- \\
-\end{array}$ & $\begin{array}{l}- \\
- \\
-\end{array}$ & $\begin{array}{c}- \\
- \\
- \\
1.20 \\
1.60\end{array}$ & $\begin{array}{c}- \\
- \\
0.47 \\
.47 \\
.28\end{array}$ & $\begin{array}{l}- \\
- \\
- \\
-\end{array}$ & $\begin{array}{l}- \\
- \\
-\end{array}$ & $\begin{array}{l}.668 \\
.095 \\
.063 \\
.050 \\
.044\end{array}$ & $\begin{array}{l}223 \\
22.0 \\
14.6 \\
11.6 \\
10.0\end{array}$ \\
\hline $\mathrm{D}_{50}$ & $\begin{array}{c}- \\
.542 \\
2.37(-6) \\
1.13(-6) \\
1.32(-7) \\
9.54(-7)\end{array}$ & $\begin{array}{l}- \\
.98 \\
1.05 \\
1.05 \\
1.04 \\
1.03\end{array}$ & $\begin{array}{l}- \\
- \\
- \\
-\end{array}$ & $\begin{array}{l}5 \\
\vdots \\
-\end{array}$ & $\begin{array}{l}- \\
- \\
-\end{array}$ & $\begin{array}{l}- \\
5 \\
-\end{array}$ & $\begin{array}{l}- \\
- \\
-\end{array}$ & $\begin{array}{c}- \\
- \\
3.23 \\
3.23 \\
3.57 \\
3.13\end{array}$ & $\begin{array}{l}- \\
- \\
- \\
.22 \\
.24 \\
.35\end{array}$ & $\begin{array}{c}- \\
- \\
- \\
-.20\end{array}$ & $\begin{array}{l}- \\
- \\
- \\
- \\
0.69 \\
.81\end{array}$ & $\begin{array}{l}.676 \\
.139 \\
.092 \\
.086 \\
.081 \\
.076\end{array}$ & $\begin{array}{l}226 \\
32.4 \\
21.3 \\
19.9 \\
18.7 \\
17.6\end{array}$ \\
\hline$D_{90}$ & $\begin{array}{l}- \\
.105 \\
1.96(-8) \\
1.82(-10) \\
5.81(-8)\end{array}$ & $\begin{array}{l}- \\
1.04 \\
1.12 \\
1.11 \\
1.08\end{array}$ & $\begin{array}{l}- \\
- \\
-\end{array}$ & $\begin{array}{l}- \\
-\end{array}$ & $\begin{array}{l}\text { - } \\
\text { - }\end{array}$ & $\begin{array}{l}- \\
- \\
-\end{array}$ & $\begin{array}{l}- \\
- \\
-\end{array}$ & $\begin{array}{l}- \\
- \\
4.05 \\
4.82 \\
3.74\end{array}$ & $\begin{array}{l}- \\
- \\
-\end{array}$ & $\begin{array}{c}- \\
- \\
- \\
-.46\end{array}$ & $\begin{array}{c}- \\
- \\
1.54 \\
1.74\end{array}$ & $\begin{array}{l}.744 \\
.262 \\
.230 \\
.221 \\
.208\end{array}$ & $\begin{array}{l}268 \\
64.0 \\
55.2 \\
53.0 \\
49.7\end{array}$ \\
\hline$M_{7,2}$ & $\begin{array}{l}- \\
.0863 \\
1.90 \\
6.22(-6) \\
2.74(-8)\end{array}$ & $\begin{array}{l}- \\
1.03 \\
1.04 \\
1.10 \\
1.08\end{array}$ & $\begin{array}{l}- \\
- \\
-\end{array}$ & $\begin{array}{l}- \\
\overline{-} \\
-\end{array}$ & $\begin{array}{l}- \\
- \\
-\end{array}$ & $\begin{array}{l}- \\
- \\
-\end{array}$ & $\begin{array}{l}- \\
-\end{array}$ & $\begin{array}{l}- \\
- \\
- \\
3.06 \\
3.93\end{array}$ & $\begin{array}{l}- \\
-\end{array}$ & $\begin{array}{c}- \\
- \\
-.77 \\
\therefore .54 \\
-.61\end{array}$ & $\begin{array}{c}- \\
= \\
- \\
2.08\end{array}$ & $\begin{array}{l}.758 \\
.306 \\
.272 \\
.260 \\
.244\end{array}$ & $\begin{array}{r}277 \\
76.4 \\
66.8 \\
63.5 \\
59.2\end{array}$ \\
\hline$M_{7,20}$ & $\begin{array}{c}- \\
.0134 \\
7.94(-4) \\
5.53(-3) \\
3.43(-4)\end{array}$ & $\begin{array}{l}- \\
1.19 \\
1.15 \\
.92 \\
.58\end{array}$ & $\begin{array}{c}- \\
- \\
- \\
\alpha-.52 \\
-1.23\end{array}$ & $\begin{array}{l}- \\
\vdots \\
-\end{array}$ & $\begin{array}{l}- \\
- \\
-\end{array}$ & $\begin{array}{l}- \\
- \\
-\end{array}$ & $\begin{array}{l}- \\
- \\
-\end{array}$ & $\begin{array}{l}- \\
\overline{-} \\
-\end{array}$ & $\begin{array}{c}- \\
- \\
- \\
1.53\end{array}$ & $\begin{array}{l}- \\
-\end{array}$ & $\begin{array}{c}- \\
- \\
\alpha 2.48 \\
3.19 \\
4.57\end{array}$ & $\begin{array}{l}.916 \\
.451 \\
.440 \\
.425 \\
.402\end{array}$ & $\begin{array}{l}406 \\
123 \\
121 \\
114 \\
106\end{array}$ \\
\hline$Q_{A}$ & $\begin{array}{l}- \\
1.12 \\
2.64(-3) \\
9.52(-4) \\
2.89(-4)\end{array}$ & $\begin{array}{l}. \\
.98 \\
1.01 \\
1.00 \\
1.06\end{array}$ & $\begin{array}{l}- \\
- \\
- \\
.10\end{array}$ & $\begin{array}{l}- \\
- \\
-\end{array}$ & - & $\begin{array}{l}- \\
- \\
-\end{array}$ & $\begin{array}{l}- \\
- \\
-\end{array}$ & $\begin{array}{c}- \\
- \\
1.58 \\
1.59 \\
1.87\end{array}$ & $\begin{array}{l}- \\
- \\
. \\
.30\end{array}$ & $\begin{array}{l}- \\
-\end{array}$ & $\begin{array}{l}- \\
- \\
-\end{array}$ & $\begin{array}{l}.661 \\
.080 \\
.062 \\
.041 \\
.037\end{array}$ & $\begin{array}{r}219 \\
18.5 \\
14.4 \\
10.6 \\
8.6\end{array}$ \\
\hline$Q_{10}$ & $\begin{array}{l}\cdot \\
\cdot 586 \\
4.79(-4)\end{array}$ & $\begin{array}{c}- \\
.99 \\
1.03\end{array}$ & - & - & - & - & - & $\begin{array}{c}- \\
1.86\end{array}$ & - & - & - & $\begin{array}{l}.674 \\
.101 \\
.082\end{array}$ & $\begin{array}{l}226 \\
23.4 \\
19.0\end{array}$ \\
\hline$Q_{11}$ & $\begin{array}{l}\cdot 790 \\
1.32(-6) \\
2.45(-6)\end{array}$ & $\begin{array}{r}- \\
.95 \\
1.02 \\
1.02\end{array}$ & $\begin{array}{l}- \\
-\end{array}$ & $\begin{array}{l}- \\
- \\
-\end{array}$ & $\begin{array}{l}- \\
- \\
- \\
0.31\end{array}$ & : & $\begin{array}{l}- \\
-\end{array}$ & $\begin{array}{c}- \\
- \\
3.48 \\
3.30\end{array}$ & :- & : & $\begin{array}{l}- \\
-\end{array}$ & $\begin{array}{l}.650 \\
.133 \\
.071 \\
.068\end{array}$ & $\begin{array}{l}212 \\
31.1 \\
17.6 \\
15.7\end{array}$ \\
\hline$Q_{12}$ & $\begin{array}{l}- \\
1.17 \\
1.85(-4) \\
8.03(-5) \\
1.24(-4)\end{array}$ & $\begin{array}{l}- \\
.96 \\
1.00 \\
1.00 \\
1.00\end{array}$ & $\begin{array}{l}- \\
- \\
-\end{array}$ & $\begin{array}{l}- \\
- \\
-\end{array}$ & $\begin{array}{l}- \\
- \\
- \\
.22\end{array}$ & $\begin{array}{l}- \\
- \\
-\end{array}$ & $\begin{array}{l}- \\
-\end{array}$ & $\begin{array}{c}- \\
- \\
2.29 \\
2.30 \\
2.17\end{array}$ & $\begin{array}{l}- \\
- \\
- \\
.25 \\
.25\end{array}$ & $\begin{array}{l}- \\
- \\
-\end{array}$ & $\begin{array}{l}- \\
- \\
-\end{array}$ & $\begin{array}{l}.650 \\
.099 \\
.066 \\
.055 \\
.052\end{array}$ & $\begin{array}{l}212 \\
23.0 \\
15.3 \\
12.8 \\
12.1\end{array}$ \\
\hline$Q_{1}$ & $\begin{array}{l}- \\
1.26 \\
1.10(-4) \\
2.72(-5) \\
4.61(-5) \\
3.26(-5)\end{array}$ & $\begin{array}{l}- \\
.98 \\
1.03 \\
1.03 \\
1.03 \\
1.03\end{array}$ & $\begin{array}{l}- \\
- \\
-\end{array}$ & $\begin{array}{l}- \\
- \\
5\end{array}$ & $\begin{array}{l}- \\
- \\
- \\
.27 \\
.27\end{array}$ & $\begin{array}{l}- \\
- \\
-\end{array}$ & $\begin{array}{l}- \\
- \\
-\end{array}$ & $\begin{array}{l}- \\
- \\
2.44 \\
2.45 \\
2.30 \\
2.37\end{array}$ & $\begin{array}{l}- \\
- \\
- \\
.42 \\
.42 \\
.40\end{array}$ & $\begin{array}{l}- \\
- \\
-\end{array}$ & $\begin{array}{l}- \\
- \\
- \\
- \\
.11\end{array}$ & $\begin{array}{l}.671 \\
.116 \\
.086 \\
.057 \\
.054 \\
.052\end{array}$ & $\begin{array}{l}224 \\
27.0 \\
19.9 \\
13.2 \\
12.5 \\
12.0\end{array}$ \\
\hline
\end{tabular}


TABLE 6.-Summary of Eastern region regression relations:

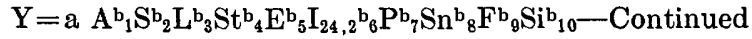

\begin{tabular}{|c|c|c|c|c|c|c|c|c|c|c|c|c|c|}
\hline \multirow{2}{*}{ 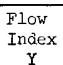 } & \multirow{2}{*}{$\begin{array}{c}\text { Regression } \\
\text { Constant } \\
a^{*}\end{array}$} & \multicolumn{10}{|c|}{ Regression Coefficients for } & \multicolumn{2}{|c|}{$\begin{array}{l}\text { Standard } \\
\text { Frror }\end{array}$} \\
\hline & & A & $\mathrm{s}$ & $\mathrm{L}$ & St & E & $I_{24,2}$ & $\mathrm{P}$ & $\mathrm{sn}$ & $\mathrm{F}$ & $\mathrm{si}$ & $\frac{\operatorname{tanr}}{\log s}$ & $\frac{r}{q}$ \\
\hline$a_{2}$ & $\begin{array}{l}- \\
1.60 \\
.446 \\
3.94(-3)\end{array}$ & $\begin{array}{r}0.99 \\
.98 \\
1.01\end{array}$ & $\overline{5}$ & $\overline{5}$ & $\overline{5}$ & $\overline{-}$ & $\overline{5}$ & $\begin{array}{c}- \\
- \\
1.24\end{array}$ & $\begin{array}{c}- \\
- \\
0.39 \\
.39\end{array}$ & $\begin{array}{l}- \\
- \\
-\end{array}$ & $\begin{array}{l}- \\
- \\
-\end{array}$ & $\begin{array}{l}0.669 \\
.090 \\
.068 \\
.055\end{array}$ & $\begin{array}{c}223 \\
20.9 \\
15.7 \\
12.8\end{array}$ \\
\hline$a_{3}$ & $\begin{array}{l}. \\
1.97 \\
.285 \\
1.74(-2)\end{array}$ & $\begin{array}{c}-. \\
.99 \\
.98 \\
1.00\end{array}$ & $\begin{array}{l}- \\
-\end{array}$ & $\overline{-}$ & 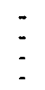 & $\overline{-}$ & $\overline{-}$ & $\begin{array}{l}- \\
- \\
.73\end{array}$ & $\begin{array}{l}- \\
- \\
.60 \\
.60\end{array}$ & $\begin{array}{l}- \\
\vdots\end{array}$ & $\begin{array}{l}- \\
\overline{-}\end{array}$ & $\begin{array}{l}.675 \\
.107 \\
.058 \\
.054\end{array}$ & $\begin{array}{l}226 \\
25.1 \\
13.4 \\
12.5\end{array}$ \\
\hline$Q_{4}$ & $\begin{array}{c}- \\
1.98 \\
.359 \\
.0208 \\
3.11(-3) \\
3.02(-3)\end{array}$ & $\begin{array}{c}- \\
.98 \\
.97 \\
.98 \\
1.06 \\
1.06\end{array}$ & $\begin{array}{c}- \\
- \\
- \\
0.17 \\
.14\end{array}$ & $\begin{array}{l}- \\
\\
-\end{array}$ & $\begin{array}{l}- \\
\overline{-} \\
\bar{z} \\
\overline{-}\end{array}$ & $\begin{array}{l}- \\
\overline{-} \\
- \\
\overline{-}\end{array}$ & $\begin{array}{l}- \\
\overline{-} \\
- \\
- \\
-\end{array}$ & $\begin{array}{c}- \\
- \\
-74 \\
.18 \\
1.19\end{array}$ & $\begin{array}{l}- \\
- \\
.52 \\
.52 \\
.32 \\
.33\end{array}$ & $\begin{array}{l}\overline{-} \\
\overline{-} \\
-\end{array}$ & $\begin{array}{c}- \\
- \\
- \\
- \\
0.08\end{array}$ & $\begin{array}{l}.663 \\
.096 \\
.054 \\
.048 \\
.041 \\
.039\end{array}$ & $\begin{array}{r}219 \\
22.3 \\
12.5 \\
11.2 \\
9.4 \\
9.0\end{array}$ \\
\hline$a_{5}$ & $\begin{array}{l}- \\
1.47 \\
.417 \\
8.52(-4) \\
2.43(-3)\end{array}$ & $\begin{array}{c}- \\
.97 \\
1.07 \\
1.13 \\
1.07\end{array}$ & $\begin{array}{l}- \\
-. \\
.24 \\
.30 \\
.18\end{array}$ & $=$ & $\begin{array}{l}- \\
- \\
-\end{array}$ & $\begin{array}{l}- \\
\vdots \\
-\end{array}$ & 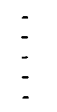 & $\begin{array}{c}- \\
- \\
- \\
1.53 \\
1.21\end{array}$ & $\begin{array}{l}- \\
- \\
- \\
.26\end{array}$ & $\begin{array}{l}- \\
- \\
-\end{array}$ & $\begin{array}{l}5 \\
-\end{array}$ & $\begin{array}{l}.659 \\
.089 \\
.064 \\
.043 \\
.035\end{array}$ & $\begin{array}{r}217 \\
20.7 \\
14.8 \\
9.9 \\
8.1\end{array}$ \\
\hline$a_{6}$ & $\begin{array}{l}-.846 \\
.00227 \\
.00104\end{array}$ & $\begin{array}{r}.98 \\
1.02 \\
1.01\end{array}$ & $\begin{array}{l}- \\
5\end{array}$ & $=$ & $\begin{array}{l}- \\
\overline{-}\end{array}$ & $\overline{-}$ & $\begin{array}{l}- \\
\overline{-}\end{array}$ & $\begin{array}{c}- \\
- \\
1.55 \\
1.55\end{array}$ & $\begin{array}{l}- \\
- \\
- \\
.24\end{array}$ & $\begin{array}{l}- \\
\overline{-} \\
-\end{array}$ & $\begin{array}{l}- \\
\overline{-}\end{array}$ & $\begin{array}{l}.664 \\
.088 \\
.073 \\
.064\end{array}$ & $\begin{array}{c}219 \\
20.4 \\
16.9 \\
14.8\end{array}$ \\
\hline$a_{7}$ & $\begin{array}{l}. \\
.499 \\
1.02(-6) \\
7.68(-5) \\
3.43(-4)\end{array}$ & $\begin{array}{r}.98 \\
1.05 \\
1.04 \\
1.04\end{array}$ & $\begin{array}{l}\overline{-} \\
\overline{5}\end{array}$ & $=$ & $\begin{array}{c}- \\
\vdots \\
0.46\end{array}$ & $\overline{5}$ & $\begin{array}{l}5 \\
5\end{array}$ & $\begin{array}{l}- \\
- \\
3.38 \\
2.61 \\
2.24\end{array}$ & $\begin{array}{l}\overline{5} \\
\bar{z}\end{array}$ & $\begin{array}{c}- \\
- \\
-0.30 \\
-.35\end{array}$ & $\begin{array}{l}\overline{-} \\
\overline{-}\end{array}$ & $\begin{array}{l}.678 \\
. .51 \\
.104 \\
.091 \\
.085\end{array}$ & $\begin{array}{l}228 \\
35.4 \\
24.2 \\
21.2 \\
19.7\end{array}$ \\
\hline$Q_{8}$ & $\begin{array}{l}-547 \\
.54 \\
3.064(-4)\end{array}$ & $\begin{array}{r}- \\
.99 \\
.99 \\
1.04\end{array}$ & $\begin{array}{l}- \\
-\end{array}$ & $=$ & $\begin{array}{l}- \\
-\end{array}$ & $\begin{array}{l}- \\
-\end{array}$ & $\begin{array}{l}- \\
-\end{array}$ & $\begin{array}{c}- \\
z \\
2.30\end{array}$ & $\begin{array}{c}- \\
-.53 \\
-.53\end{array}$ & $\begin{array}{l}- \\
\vdots\end{array}$ & : & $\begin{array}{l}.677 \\
.135 \\
.109 \\
.079\end{array}$ & $\begin{array}{l}228 \\
31.6 \\
25.4 \\
18.3\end{array}$ \\
\hline$a_{9}$ & $\begin{array}{l}. \\
.417 \\
6.17(-6) \\
1.57(-5)\end{array}$ & $\begin{array}{c}- \\
.99 \\
1.05 \\
1.06\end{array}$ & $\begin{array}{l}- \\
-\end{array}$ & 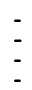 & $\begin{array}{l}- \\
-\end{array}$ & $\begin{array}{l}- \\
- \\
-\end{array}$ & $\begin{array}{l}- \\
\overline{-}\end{array}$ & $\begin{array}{c}- \\
2.91 \\
2.90\end{array}$ & $\begin{array}{c}- \\
- \\
-.28\end{array}$ & : & $\begin{array}{l}5 \\
-\end{array}$ & $\begin{array}{l}.683 \\
.146 \\
.112 \\
.105\end{array}$ & $\begin{array}{r}231 \\
34.2 \\
26.1 \\
24.4\end{array}$ \\
\hline $\mathrm{SD}_{\mathrm{A}}$ & $\begin{array}{l}.364 \\
.0142\end{array}$ & $\begin{array}{l}.98 \\
.99 \\
\end{array}$ & 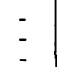 & - & : & $\overline{-}$ & 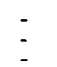 & $\begin{array}{l}- \\
.85\end{array}$ & - & $=$ & $\overline{-}$ & $\begin{array}{l}.659 \\
.060 \\
.054\end{array}$ & $\begin{array}{c}216 \\
14.0 \\
12.5\end{array}$ \\
\hline $\mathrm{SD}_{10}$ & $\begin{array}{c}.664 \\
.221 \\
7.82\end{array}$ & $\begin{array}{l}- \\
1.02 \\
1.02 \\
1.03\end{array}$ & $\begin{array}{l}- \\
-\end{array}$ & $\overline{-}$ & $\begin{array}{l}- \\
\overline{-}\end{array}$ & $\begin{array}{c}- \\
- \\
-0.21\end{array}$ & $\begin{array}{l}- \\
\overline{-}\end{array}$ & : & $\begin{array}{l}- \\
-\end{array}$ & $\begin{array}{ll}- \\
\mathrm{d} \\
.28 \\
.40\end{array}$ & : & $\begin{array}{l}.705 \\
.172 \\
.166 \\
.158\end{array}$ & $\begin{array}{c}244 \\
40.6 \\
39.1 \\
37.1\end{array}$ \\
\hline $\mathrm{SD}_{11}$ & $\begin{array}{l}.653 \\
4.09(-5)\end{array}$ & $\begin{array}{c}- \\
.94 \\
1.00\end{array}$ & 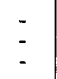 & 5 & $\overline{-}$ & : & $\overline{-}$ & $\begin{array}{c}- \\
- \\
2.53\end{array}$ & $\overline{-}$ & $\overline{-}$ & $\overline{-}$ & $\begin{array}{l}.650 \\
.139 \\
.113\end{array}$ & $\begin{array}{c}213 \\
32.6 \\
26.3\end{array}$ \\
\hline $\mathrm{SD}_{12}$ & $\begin{array}{l}.899 \\
.0328 \\
.00207\end{array}$ & $\begin{array}{l}-. \\
.96 \\
.98 \\
.99\end{array}$ & $\begin{array}{l}- \\
-\end{array}$ & $=$ & : & $\begin{array}{l}- \\
\overline{-}\end{array}$ & $\overline{-}$ & $\begin{array}{c}- \\
- \\
\text { d. } 87 \\
1.38\end{array}$ & : & $\begin{array}{l}- \\
- \\
.20\end{array}$ & $\begin{array}{l}\overline{-} \\
-\end{array}$ & $\begin{array}{l}.654 \\
.092 \\
.089 \\
.083\end{array}$ & $\begin{array}{c}214 \\
21.4 \\
20.7 \\
19.2\end{array}$ \\
\hline $\mathrm{SD}_{1}$ & $\begin{array}{l}-750 \\
.00377 \\
.00140 \\
.000137\end{array}$ & $\begin{array}{l}- \\
1.00 \\
1.03 \\
1.03 \\
1.04\end{array}$ & $\begin{array}{l}\overline{-} \\
\overline{-}\end{array}$ & $\overline{-}$ & $\begin{array}{l}\overline{-} \\
\overline{-}\end{array}$ & $\begin{array}{l}\overline{-} \\
\overline{-}\end{array}$ & $=$ & $\begin{array}{c}- \\
- \\
1.38 \\
1.56 \\
1.99\end{array}$ & $\begin{array}{l}- \\
\overline{-}\end{array}$ & $\begin{array}{l}- \\
- \\
. \\
.18\end{array}$ & $\begin{array}{l}- \\
- \\
-.25 \\
.23\end{array}$ & $\begin{array}{l}.682 \\
.106 \\
.097 \\
.089 \\
.085\end{array}$ & $\begin{array}{c}230 \\
24.6 \\
22.5 \\
20.7 \\
19.7\end{array}$ \\
\hline
\end{tabular}


RESULTS

TABLE 6.-Summary of Eastern region regression relations:

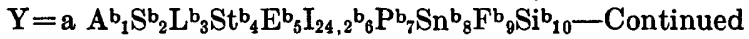

\begin{tabular}{|c|c|c|c|c|c|c|c|c|c|c|c|c|c|}
\hline \multirow{2}{*}{$\begin{array}{l}\text { Flow } \\
\text { Index } \\
y\end{array}$} & \multirow{2}{*}{$\begin{array}{c}\text { Regression } \\
\text { Constant } \\
a^{*}\end{array}$} & \multicolumn{10}{|c|}{ Regression Coefficients for } & \multicolumn{2}{|c|}{$\begin{array}{l}\text { Standard } \\
\text { Error }\end{array}$} \\
\hline & & A & $\mathbf{S}$ & L & St & E & $\mathrm{I}_{24,2}$ & $\mathbf{P}$ & Sn & $\mathbf{F}$ & Si & $\frac{\operatorname{Er}}{\log s}$ & $\%$ \\
\hline$S D_{2}$ & $\begin{array}{l}. \\
0.785 \\
.437 \\
.00493\end{array}$ & $\begin{array}{l}1.01 \\
1.01 \\
1.03\end{array}$ & - & $\begin{array}{l}- \\
- \\
-\end{array}$ & $\begin{array}{l}- \\
- \\
-\end{array}$ & $\begin{array}{l}- \\
- \\
-\end{array}$ & $\begin{array}{l}- \\
- \\
-\end{array}$ & $\begin{array}{l}- \\
- \\
1.09\end{array}$ & $\begin{array}{l}\overline{-} \\
\overline{-}\end{array}$ & $\begin{array}{c}- \\
\overline{0} \\
0.15 \\
.23\end{array}$ & $\begin{array}{l}- \\
- \\
-\end{array}$ & $\begin{array}{l}0.684 \\
.090 \\
.087 \\
.081\end{array}$ & $\begin{array}{r}231 \\
20.9 \\
20.2 \\
18.7\end{array}$ \\
\hline $\mathrm{SD}_{3}$ & $\begin{array}{l}. \\
.760 \\
.169\end{array}$ & $\begin{array}{l}- \\
1.05 \\
1.05\end{array}$ & - & - & - & $\begin{array}{l}- \\
-\end{array}$ & $\begin{array}{l}- \\
-\end{array}$ & $\begin{array}{l}- \\
-\end{array}$ & $\overline{-}$ & $\begin{array}{l}- \\
.38\end{array}$ & - & $\begin{array}{l}.719 \\
.150 \\
.133\end{array}$ & $\begin{array}{r}252 \\
35.2 \\
31.1\end{array}$ \\
\hline $\mathrm{SD}_{4}$ & $\begin{array}{l}- \\
.912 \\
.415 \\
.00634\end{array}$ & $\begin{array}{r}. \\
.99 \\
.99 \\
1.01\end{array}$ & $\begin{array}{l}\ddot{-} \\
\dot{-}\end{array}$ & $\begin{array}{l}- \\
-\end{array}$ & $\begin{array}{l}- \\
- \\
-\end{array}$ & $\begin{array}{l}- \\
- \\
=\end{array}$ & $\begin{array}{l}- \\
-\end{array}$ & $\begin{array}{c}- \\
- \\
1.01\end{array}$ & $\begin{array}{l}- \\
-\end{array}$ & $\begin{array}{l}- \\
. \\
.20 \\
.27\end{array}$ & $\begin{array}{l}- \\
- \\
-\end{array}$ & $\begin{array}{l}.671 \\
.094 \\
.087 \\
.083\end{array}$ & $\begin{array}{r}224 \\
21.8 \\
20.2 \\
19.2\end{array}$ \\
\hline $\mathrm{SD}_{5}$ & $\begin{array}{l}. \\
.738 \\
.315 \\
.340\end{array}$ & $\begin{array}{r}. \\
.98 \\
.98 \\
1.24\end{array}$ & - & $\begin{array}{c}= \\
-0.44\end{array}$ & $\begin{array}{l}- \\
- \\
-\end{array}$ & $\begin{array}{l}- \\
- \\
-\end{array}$ & $\begin{array}{l}- \\
- \\
-\end{array}$ & $\begin{array}{l}- \\
\overline{-} \\
\overline{-}\end{array}$ & $\begin{array}{l}- \\
\overline{-}\end{array}$ & $\begin{array}{l}- \\
- \\
.21 \\
.25\end{array}$ & $\begin{array}{l}- \\
- \\
-\end{array}$ & $\begin{array}{l}.670 \\
.110 \\
.103 \\
.096\end{array}$ & $\begin{array}{r}223 \\
25.6 \\
23.9 \\
22.3\end{array}$ \\
\hline $\mathrm{sD}_{6}$ & $\begin{array}{l}- \\
.635 \\
.307\end{array}$ & $\begin{array}{l}.97 \\
.96\end{array}$ & - & $\begin{array}{l}- \\
-\end{array}$ & $\begin{array}{l}- \\
-\end{array}$ & - & $\begin{array}{l}- \\
-\end{array}$ & - & - & $\begin{array}{l}- \\
.18\end{array}$ & $\begin{array}{l}- \\
-\end{array}$ & $\begin{array}{l}.658 \\
.108 \\
.103\end{array}$ & $\begin{array}{l}216 \\
25.1 \\
23.9\end{array}$ \\
\hline $\mathrm{SD}_{7}$ & $\begin{array}{l}- \\
.626 \\
.933 \\
1.50 \\
.00520 \\
.0113\end{array}$ & $\begin{array}{l}- \\
.92 \\
1.40 \\
1.40 \\
1.35 \\
1.32\end{array}$ & $\begin{array}{l}\overline{-} \\
\overline{-} \\
\overline{-} \\
\overline{-}\end{array}$ & $\begin{array}{r}- \\
- \\
-.83 \\
-.82 \\
-.68 \\
-.63\end{array}$ & $\begin{array}{l}- \\
- \\
- \\
- \\
0.44\end{array}$ & $\begin{array}{l}- \\
- \\
- \\
-\end{array}$ & $\begin{array}{l}- \\
\overline{-} \\
- \\
-\end{array}$ & $\begin{array}{c}- \\
- \\
- \\
1.45 \\
1.24\end{array}$ & $\begin{array}{l}\overline{-} \\
\overline{-} \\
\overline{-}\end{array}$ & i & $\begin{array}{c}- \\
- \\
-0.38 \\
-.34 \\
-.33\end{array}$ & $\begin{array}{l}.635 \\
.148 \\
.127 \\
.112 \\
.103 \\
.098\end{array}$ & $\begin{array}{r}204 \\
34.7 \\
29.7 \\
26.1 \\
23.9 \\
22.7\end{array}$ \\
\hline $\mathrm{sD}_{8}$ & .830 & .93 & - & $\overrightarrow{-}$ & - & - & - & - & $\overline{-}$ & - & $\overline{-}$ & $\begin{array}{l}.651 \\
.190\end{array}$ & $\begin{array}{l}213 \\
45.1\end{array}$ \\
\hline $\mathrm{SD}_{9}$ & -.567 & .96 & - & - & - & - & - & - & $\overline{-}$ & $\overline{-}$ & - & $\begin{array}{r}.660 \\
.144\end{array}$ & $\begin{array}{l}218 \\
33.8\end{array}$ \\
\hline
\end{tabular}

* Number in ( ) is power of 10 by which value must be multiplied.

TABLE 7.-Summary of Central region regression relations:

$\mathrm{Y}=\mathrm{a} \mathrm{A}_{1} \mathrm{~b}_{1} \mathrm{~b}_{3} \mathrm{~Pb}_{7} \mathrm{Sn}^{\mathrm{b}}{ }_{8} \mathrm{Si}^{\mathrm{b}}{ }_{10} \mathrm{t}_{7} \mathrm{~b}_{11} \mathrm{t}_{1} \mathrm{~b}_{12} \mathrm{Ev}^{\mathrm{b}}{ }_{13} \mathrm{~A}_{\mathrm{a}} \mathrm{b}_{14}$

[All regression coefficients are statistically significant at the 5 percent level, except those preceded by $d$ ]

\begin{tabular}{|c|c|c|c|c|c|c|c|c|c|c|c|c|c|}
\hline \multirow{2}{*}{$\begin{array}{l}\text { Flow } \\
\text { Index } \\
y\end{array}$} & \multirow{2}{*}{$\begin{array}{c}\text { Regression } \\
\text { Constant } \\
a^{*}\end{array}$} & \multicolumn{10}{|c|}{ Regression Coefficients for } & \multicolumn{2}{|c|}{$\begin{array}{l}\text { Standard } \\
\text { Error }\end{array}$} \\
\hline & & A & L & $\mathbf{P}$ & $\mathrm{Sn}$ & Si & $t_{7}$ & $t_{1}$ & Ev & $\mathrm{A}_{\mathrm{a}}$ & - & & 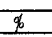 \\
\hline$P_{50}$ & $\begin{array}{c}- \\
2.77(7) \\
1.51(7) \\
4.18(6)\end{array}$ & $\begin{array}{c}- \\
- \\
0.33 \\
.71\end{array}$ & $\begin{array}{c}- \\
- \\
-0.64\end{array}$ & $\begin{array}{l}- \\
- \\
-\end{array}$ & $\begin{array}{c}- \\
-2.21 \\
-2.76 \\
-2.23\end{array}$ & $\begin{array}{l}- \\
- \\
-\end{array}$ & $\begin{array}{l}- \\
- \\
-\end{array}$ & $\begin{array}{l}- \\
- \\
-\end{array}$ & $\begin{array}{l}- \\
\overline{-}\end{array}$ & - & & $\begin{array}{l}0.359 \\
.296 \\
.254 \\
.239\end{array}$ & $\begin{array}{l}91.9 \\
73.5 \\
61.9 \\
57.8\end{array}$ \\
\hline$P_{20}$ & $\begin{array}{c}84.4 \\
.498 \\
2600.52\end{array}$ & $\begin{array}{l}- \\
- \\
.40 \\
.78 \\
.74\end{array}$ & $\begin{array}{l}- \\
- \\
- \\
-.69 \\
-.63\end{array}$ & $\begin{array}{l}- \\
1.74 \\
2.48 \\
1.90 \\
1.19\end{array}$ & $\begin{array}{c}- \\
\overline{-} \\
-1.27\end{array}$ & $\begin{array}{l}- \\
\overline{-} \\
-\end{array}$ & $\begin{array}{l}\bar{z} \\
\bar{z}\end{array}$ & $\begin{array}{l}\bar{z} \\
\overline{-} \\
\overline{-}\end{array}$ & $\begin{array}{l}\text { - } \\
\text { - } \\
\text { - }\end{array}$ & $\begin{array}{l}- \\
\overline{-} \\
- \\
-\end{array}$ & & $\begin{array}{r}.351 \\
.288 \\
.230 \\
.211 \\
.198\end{array}$ & $\begin{array}{l}91.6 \\
72.1 \\
55.1 \\
50.5 \\
47.1\end{array}$ \\
\hline$P_{10}$ & $\begin{array}{c}- \\
36.6 \\
.222 \\
3.27 \\
500.5\end{array}$ & $\begin{array}{l}- \\
- \\
.39 \\
.82 \\
.79\end{array}$ & $\begin{array}{c}- \\
- \\
- \\
-.77 \\
-.72\end{array}$ & $\begin{array}{l}- \\
1.90 \\
2.63 \\
1.99 \\
1.40\end{array}$ & $\begin{array}{c}= \\
= \\
-1.04\end{array}$ & $\begin{array}{l}- \\
\overline{-} \\
\overline{-}\end{array}$ & $\overline{-}$ & $\begin{array}{l}\overline{-} \\
\overline{-} \\
\overline{-}\end{array}$ & $\begin{array}{l}- \\
- \\
-\end{array}$ & $\begin{array}{l}- \\
- \\
-\end{array}$ & & $\begin{array}{l}.355 \\
.280 \\
.219 \\
.193 \\
.184\end{array}$ & $\begin{array}{l}90.4 \\
69.8 \\
52.7 \\
45.9 \\
43.6\end{array}$ \\
\hline$P_{5}$ & $\begin{array}{c}- \\
14.6 \\
.0830 \\
1.50\end{array}$ & $\begin{array}{l}- \\
. \\
.40 \\
.86\end{array}$ & $\begin{array}{c}- \\
- \\
-.83\end{array}$ & $\begin{array}{l}- \\
2.06 \\
2.80 \\
2.11\end{array}$ & $\begin{array}{l}\bar{z} \\
\overline{-}\end{array}$ & $\begin{array}{l}- \\
- \\
-\end{array}$ & $\dot{-}$ & $\begin{array}{l}\bar{z} \\
\bar{z}\end{array}$ & $\begin{array}{l}- \\
-\end{array}$ & $\begin{array}{l}- \\
\overline{-}\end{array}$ & & $\begin{array}{l}.369 \\
.281 \\
.219 \\
.188\end{array}$ & $\begin{array}{l}95.1 \\
69.3 \\
52.5 \\
44.6\end{array}$ \\
\hline
\end{tabular}


TABLE 7.-Summary of Central region regression relations:

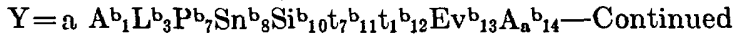

\begin{tabular}{|c|c|c|c|c|c|c|c|c|c|c|c|c|c|}
\hline \multirow{2}{*}{$\begin{array}{c}\text { Flow } \\
\text { Index } \\
y \\
\end{array}$} & \multirow{2}{*}{$\begin{array}{c}\text { Regression } \\
\text { Constant } \\
a^{*}\end{array}$} & \multicolumn{10}{|c|}{ Regression Coefficients for } & \multicolumn{2}{|c|}{$\begin{array}{l}\text { Standard } \\
\text { Error }\end{array}$} \\
\hline & & A & L & $\mathbf{P}$ & $\mathrm{sn}$ & si & $t_{7}$ & $\mathrm{t}_{1}$ & Ev & $A_{a}$ & - & & 9 \\
\hline $\mathrm{P}_{2}$ & $\begin{array}{l}3.12 \\
.0124 \\
.201\end{array}$ & $\begin{array}{c}- \\
- \\
0.43 \\
.87\end{array}$ & $\begin{array}{c}- \\
- \\
-0.80\end{array}$ & $\begin{array}{l}- \\
2.29 \\
3.08 \\
2.42\end{array}$ & $\begin{array}{l}- \\
-\end{array}$ & $\begin{array}{l}- \\
-\end{array}$ & $\begin{array}{l}- \\
- \\
-\end{array}$ & $\begin{array}{l}- \\
- \\
-\end{array}$ & : & - & & $\begin{array}{r}0.398 \\
.297 \\
.230 \\
.204\end{array}$ & $\begin{array}{r}105.1 \\
73.8 \\
55.4 \\
48.5\end{array}$ \\
\hline $\mathrm{P}_{1.1}$ & $\begin{array}{l}- \\
.524 \\
.000640 \\
1.65(-7)\end{array}$ & $\begin{array}{l}- \\
- \\
.52 \\
.63\end{array}$ & $\begin{array}{l}- \\
- \\
-\end{array}$ & $\begin{array}{l}- \\
2.40 \\
3.37 \\
5.08\end{array}$ & : & $\begin{array}{c}- \\
- \\
1.87\end{array}$ & : & : & - & - & & $\begin{array}{l}.477 \\
.350 \\
.265 \\
.241\end{array}$ & $\begin{array}{r}121.6 \\
89.6 \\
64.8 \\
58.5\end{array}$ \\
\hline$v_{3,50}$ & $\begin{array}{l}20.2 \\
.000908 \\
.399\end{array}$ & $\begin{array}{l}- \\
- \\
.77 \\
.77\end{array}$ & : & $\begin{array}{l}. \\
2.01 \\
3.46 \\
2.72\end{array}$ & $\begin{array}{c}- \\
- \\
-1.21\end{array}$ & $\begin{array}{l}\overline{-} \\
\overline{-}\end{array}$ & : & $\begin{array}{l}- \\
- \\
-\end{array}$ & - & $\begin{array}{l}\overline{-} \\
\overline{-}\end{array}$ & & $\begin{array}{l}.463 \\
.403 \\
.207 \\
.195\end{array}$ & $\begin{array}{r}125.4 \\
106.7 \\
49.4 \\
46.3\end{array}$ \\
\hline$v_{3,20}$ & $\begin{array}{l}6.94 \\
.000387 \\
.0874\end{array}$ & $\begin{array}{l}- \\
-76 \\
.75\end{array}$ & $\begin{array}{l}- \\
\overline{-}\end{array}$ & $\begin{array}{r}- \\
2.24 \\
3.65 \\
3.00\end{array}$ & $\begin{array}{c}- \\
- \\
-1.08\end{array}$ & : & $\begin{array}{l}- \\
-\end{array}$ & $\begin{array}{l}- \\
-\end{array}$ & $\overline{-}$ & $\overline{-}$ & & $\begin{array}{l}.457 \\
.378 \\
.168 \\
.155\end{array}$ & $\begin{array}{c}126 \\
97.7 \\
39.5 \\
36.4\end{array}$ \\
\hline$v_{3,10}$ & $\begin{array}{l}. .85 \\
.000138 \\
.0234\end{array}$ & $\begin{array}{l}- \\
- \\
.77 \\
.76\end{array}$ & $\begin{array}{l}- \\
- \\
-\end{array}$ & $\begin{array}{l}- \\
2.42 \\
3.85 \\
3.23\end{array}$ & $\begin{array}{c}- \\
- \\
-1.02\end{array}$ & $\begin{array}{l}- \\
- \\
-\end{array}$ & - & $\begin{array}{l}- \\
-\end{array}$ & $\begin{array}{l}- \\
-\end{array}$ & $\begin{array}{l}- \\
- \\
-\end{array}$ & & $\begin{array}{l}.471 \\
.373 \\
.146 \\
.132\end{array}$ & $\begin{array}{l}130 \\
97.6 \\
34.1 \\
30.9\end{array}$ \\
\hline$v_{3,2}$ & $\begin{array}{c}- \\
.201 \\
5.37(-6) \\
.000167\end{array}$ & $\begin{array}{l}- \\
- \\
.81 \\
.81\end{array}$ & $\begin{array}{l}- \\
-\end{array}$ & $\begin{array}{l}- \\
2.86 \\
4.38 \\
3.97\end{array}$ & $\begin{array}{l}- \\
- \\
-.68\end{array}$ & $\begin{array}{l}- \\
-\end{array}$ & $\overline{-}$ & $\begin{array}{l}- \\
-\end{array}$ & - & 5 & & $\begin{array}{l}.512 \\
.389 \\
.136 \\
.131\end{array}$ & $\begin{array}{l}147 \\
102 \\
31.8 \\
30.6\end{array}$ \\
\hline$v_{7,50}$ & $\begin{array}{l}270- \\
.000156 \\
.0718\end{array}$ & $\begin{array}{l}- \\
.49 \\
.88 \\
.87\end{array}$ & - & $\begin{array}{c}- \\
- \\
3.62 \\
2.88\end{array}$ & $\begin{array}{c}- \\
- \\
- \\
-1.22\end{array}$ & - & - & $\begin{array}{l}- \\
-\end{array}$ & - & $\begin{array}{l}- \\
- \\
-\end{array}$ & & $\begin{array}{l}.489 \\
.429 \\
.189 \\
.175\end{array}$ & $\begin{array}{l}138 \\
116 \\
45.0 \\
41.4\end{array}$ \\
\hline$v_{7,20}$ & $\begin{array}{l}-. \\
4.24 \\
5.61(-5) \\
.0143\end{array}$ & $\begin{array}{l}- \\
.87 \\
.86\end{array}$ & : & $\begin{array}{l}- \\
2.23 \\
3.85 \\
3.18\end{array}$ & $\begin{array}{c}- \\
- \\
-1.10\end{array}$ & : & $\overline{-}$ & 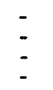 & $\overline{-}$ & $\overline{-}$ & & $\begin{array}{l}.488 \\
.417 \\
.151 \\
.135\end{array}$ & $\begin{array}{l}138 \\
112 \\
35.3 \\
31.6\end{array}$ \\
\hline$v_{7,10}$ & $\begin{array}{l}- \\
1.70 \\
2.30(-5) \\
.00323\end{array}$ & $\begin{array}{l}- \\
-.86 \\
.86\end{array}$ & - & $\begin{array}{l}- \\
2.42 \\
4.03 \\
3.44\end{array}$ & $\begin{array}{c}- \\
- \\
- \\
-.98\end{array}$ & : & $\begin{array}{l}- \\
-\end{array}$ & : & $\begin{array}{l}- \\
-\end{array}$ & $\begin{array}{l}- \\
-\end{array}$ & & $\begin{array}{l}.494 \\
.409 \\
.128 \\
.113\end{array}$ & $\begin{array}{l}141 \\
109 \\
29.9 \\
26.3\end{array}$ \\
\hline$v_{7,2}$ & $\begin{array}{l}- \\
.131 \\
1.32(-6) \\
2.89(-5)\end{array}$ & $\begin{array}{l}- \\
.89 \\
.88\end{array}$ & $\overline{-}$ & $\begin{array}{l}- \\
2.83 \\
4.49 \\
4.12\end{array}$ & $\begin{array}{c}- \\
- \\
-.61\end{array}$ & $\overline{-}$ & $\begin{array}{l}- \\
-\end{array}$ & $\overline{-}$ & 5 & $:$ & & $\begin{array}{l}.530 \\
.417 \\
.121 \\
.116\end{array}$ & $\begin{array}{l}155 \\
111 \\
28.2 \\
27.1\end{array}$ \\
\hline$D_{10}$ & $\begin{array}{l}- \\
2.42 \\
1.08(-8)\end{array}$ & $\begin{array}{r}- \\
.66 \\
1.17\end{array}$ & - & $\begin{array}{c}- \\
4.84\end{array}$ & - & $\overline{-}$ & - & $\overline{-}$ & - & - & & $\begin{array}{l}.646 \\
.565 \\
.229\end{array}$ & $\begin{array}{l}210 \\
170 \\
55.2\end{array}$ \\
\hline$D_{50}$ & $\begin{array}{l}- \\
.182 \\
7.36(-8) \\
5.51(-12)\end{array}$ & $\begin{array}{r}- \\
.73 \\
1.12 \\
1.25\end{array}$ & 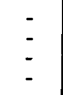 & $\begin{array}{c}- \\
- \\
3.70 \\
5.67\end{array}$ & $\begin{array}{l}- \\
-\end{array}$ & $\begin{array}{c}- \\
- \\
2.15\end{array}$ & : & $\begin{array}{l}- \\
-\end{array}$ & - & $\begin{array}{l}- \\
-\end{array}$ & & $\begin{array}{l}.637 \\
.532 \\
.359 \\
.338\end{array}$ & $\begin{array}{l}206 \\
155 \\
92.8 \\
86.0\end{array}$ \\
\hline$D_{80}$ & $\begin{array}{c}. \\
.00157 \\
7.48(-10) \\
4.46(-19)\end{array}$ & $\begin{array}{l}- \\
1.15 \\
1.53 \\
1.82\end{array}$ & $\overline{-}$ & $\begin{array}{c}- \\
- \\
3.60 \\
8.01\end{array}$ & $\begin{array}{l}- \\
-\end{array}$ & $\begin{array}{c}- \\
- \\
4.80\end{array}$ & $\begin{array}{l}- \\
- \\
-\end{array}$ & $\begin{array}{l}- \\
-\end{array}$ & $\overline{-}$ & $\begin{array}{l}- \\
- \\
-\end{array}$ & & $\begin{array}{l}.952 \\
.772 \\
.677 \\
.617\end{array}$ & $\begin{array}{l}441 \\
288 \\
227 \\
195\end{array}$ \\
\hline$M_{7,2}$ & $\begin{array}{c}- \\
4.79(6) \\
3.95(5) \\
6.31 \\
4.51(-10) \\
187\end{array}$ & $\begin{array}{c}- \\
1.36 \\
1.46 \\
1.75 \\
1.65\end{array}$ & $\begin{array}{l}- \\
\vdots \\
-\end{array}$ & $\begin{array}{c}- \\
- \\
- \\
\text { d1. } \\
6.48 \\
8.28\end{array}$ & $\begin{array}{l}- \\
-4.92 \\
-7.19 \\
-5.68 \\
-5.22 \\
-8.59\end{array}$ & $\begin{array}{c}- \\
- \\
- \\
4.76 \\
4.91\end{array}$ & $\begin{array}{l}- \\
\overline{-} \\
- \\
-\end{array}$ & $\begin{array}{c}- \\
= \\
- \\
-7.69\end{array}$ & $\begin{array}{l}- \\
\overline{-} \\
- \\
-\end{array}$ & $\begin{array}{l}- \\
5 \\
-\end{array}$ & & $\begin{array}{r}1.163 \\
1.080 \\
.875 \\
.876 \\
.836 \\
.798\end{array}$ & $\begin{array}{l}661 \\
599 \\
368 \\
368 \\
335 \\
306\end{array}$ \\
\hline
\end{tabular}


TABLE 7.-Summary of Central region regression relations:

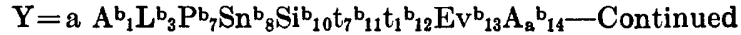

\begin{tabular}{|c|c|c|c|c|c|c|c|c|c|c|c|c|c|}
\hline \multirow{2}{*}{$\begin{array}{l}\text { Flow } \\
\text { Index } \\
\mathrm{Y}\end{array}$} & \multirow{2}{*}{$\begin{array}{c}\text { Regression } \\
\text { Constant } \\
a^{*}\end{array}$} & \multicolumn{10}{|c|}{ Regression Coefficients for } & \multicolumn{2}{|c|}{ Standard } \\
\hline & & A & $\mathrm{L}$ & $\mathbf{P}$ & $\mathrm{Sn}$ & $\mathrm{Si}$ & $t_{7}$ & $t_{1}$ & Ev & $\mathrm{A}_{\mathrm{a}}$ & - & $\begin{array}{c}\text { Erro } \\
\operatorname{logs}\end{array}$ & $\%$ \\
\hline$M_{7,10}$ & $\begin{array}{l}- \\
2.50(-6) \\
2.34(-12)\end{array}$ & $\begin{array}{l}- \\
1.52 \\
1.89\end{array}$ & $\begin{array}{l}E \\
-\end{array}$ & $\begin{array}{c}- \\
3.49\end{array}$ & $\overline{-}$ & $\overline{-}$ & $=$ & $\overline{-}$ & $\bar{E}$ & $:$ & & $\begin{array}{r}1.251 \\
1.011 \\
.952\end{array}$ & $\begin{array}{r}1060 \\
510 \\
442\end{array}$ \\
\hline$M_{7}, 20$ & $7 \cdot 31(-6)$ & $\begin{array}{c}- \\
1.29\end{array}$ & - & - & - & - & - & - & - & - & & $\begin{array}{r}1.113 \\
.921\end{array}$ & $\begin{array}{l}712 \\
410\end{array}$ \\
\hline$Q_{a}$ & $\begin{array}{l}- \\
6.0216 \\
6.00(-8)\end{array}$ & $\begin{array}{l}- \\
.99\end{array}$ & $\begin{array}{l}- \\
-\end{array}$ & $\begin{array}{l}- \\
2.71 \\
4.56\end{array}$ & $\overline{-}$ & - & - & - & $\begin{array}{l}- \\
\overline{-}\end{array}$ & - & & $\begin{array}{l}.555 \\
.460 \\
.121\end{array}$ & $\begin{array}{c}166 \\
127 \\
28.2\end{array}$ \\
\hline$Q_{10}$ & $\begin{array}{l}- \\
4.45(-3) \\
1.60(-8) \\
6.28(-25)\end{array}$ & $\begin{array}{l}- \\
. \\
.97 \\
.95\end{array}$ & $\begin{array}{l}- \\
\overline{-} \\
-\end{array}$ & $\begin{array}{l}- \\
3.09 \\
4.90 \\
4.01\end{array}$ & $\begin{array}{l}- \\
-\end{array}$ & - & $\begin{array}{c}- \\
- \\
8.27\end{array}$ & : & - & $\begin{array}{l}- \\
-\end{array}$ & & $\begin{array}{l}.581 \\
.459 \\
.147 \\
.141\end{array}$ & $\begin{array}{c}178 \\
1.26 \\
34.5 \\
33.0\end{array}$ \\
\hline$Q_{11}$ & $\begin{array}{l}- \\
1.08(-3) \\
1.31(-10) \\
1.69(-13)\end{array}$ & $\begin{array}{l}- \\
- \\
1.05 \\
1.14\end{array}$ & $\begin{array}{l}\overline{-} \\
\overline{-}\end{array}$ & $\begin{array}{l}- \\
4.03 \\
6.00 \\
7.38\end{array}$ & $\begin{array}{l}- \\
\overline{-}\end{array}$ & $\begin{array}{c}: \\
- \\
1.50\end{array}$ & : & : & $\overline{-}$ & $\begin{array}{l}5 \\
\vdots\end{array}$ & & $\begin{array}{l}.692 \\
.509 \\
.192 \\
.170\end{array}$ & $\begin{array}{l}235 \\
146 \\
45.7 \\
40.2\end{array}$ \\
\hline $\mathrm{Q}_{12}$ & $\begin{array}{l}- \\
1.69(-4) \\
1.12(-9) \\
1.33(-12)\end{array}$ & $\begin{array}{c}- \\
- \\
.92 \\
1.01\end{array}$ & $\begin{array}{l}- \\
\overline{-}\end{array}$ & $\begin{array}{l}- \\
3.82 \\
5.54 \\
6.94\end{array}$ & $\begin{array}{l}- \\
-\end{array}$ & $\begin{array}{c}- \\
- \\
1.52\end{array}$ & - & $\bar{z}$ & $\begin{array}{l}- \\
\overline{-}\end{array}$ & $\begin{array}{l}- \\
- \\
-\end{array}$ & & $\begin{array}{l}.638 \\
.458 \\
.199 \\
.177\end{array}$ & $\begin{array}{l}206 \\
126 \\
47.3 \\
42.0\end{array}$ \\
\hline$Q_{1}$ & $\begin{array}{l}- \\
6.12(-5) \\
2.65(-10) \\
1.76(-13)\end{array}$ & $\begin{array}{c}- \\
.95 \\
1.05\end{array}$ & 5 & $\begin{array}{l}- \\
4.15 \\
5.93 \\
7.44\end{array}$ & 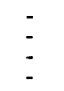 & $\begin{array}{c}- \\
- \\
1.66\end{array}$ & $\overline{-}$ & $\bar{z}$ & $\overline{-}$ & $\begin{array}{l}- \\
-\end{array}$ & & $\begin{array}{l}.683 \\
.483 \\
.227 \\
.205\end{array}$ & $\begin{array}{r}231 \\
136 \\
54.5 \\
48.9\end{array}$ \\
\hline$Q_{2}$ & $\begin{array}{l}- \\
9.55(-4) \\
2.76(-9) \\
1.67(-11) \\
8.34(-11)\end{array}$ & $\begin{array}{l}- \\
-.98 \\
1.05 \\
1.04\end{array}$ & $\begin{array}{l}- \\
- \\
-\end{array}$ & $\begin{array}{l}- \\
3.45 \\
5.29 \\
6.35 \\
7.17\end{array}$ & $\begin{array}{l}- \\
- \\
-\end{array}$ & $\begin{array}{l}- \\
- \\
1.16 \\
1.25\end{array}$ & $\begin{array}{l}- \\
- \\
-\end{array}$ & $\begin{array}{c}- \\
- \\
- \\
-1.50\end{array}$ & $\begin{array}{l}- \\
- \\
-\end{array}$ & $\begin{array}{l}- \\
- \\
-\end{array}$ & & $\begin{array}{l}.632 \\
.490 \\
.212 \\
.202 \\
.193\end{array}$ & $\begin{array}{l}202 \\
140 \\
50.7 \\
48.1 \\
45.7\end{array}$ \\
\hline$Q_{3}$ & $\begin{array}{l}- \\
4.92(-4) \\
5.80(-9) \\
6.52(-8) \\
3.25(-8) \\
6.84(-10)\end{array}$ & $\begin{array}{l}. \\
.88 \\
.85 \\
.85 \\
1.12 \\
1.26\end{array}$ & $\begin{array}{l}- \\
:\end{array}$ & $\begin{array}{l}- \\
3.81 \\
5.45 \\
6.32 \\
6.46 \\
7.33\end{array}$ & $\begin{array}{l}: \\
: \\
-\end{array}$ & $\begin{array}{l}5 \\
5 \\
5 \\
.85\end{array}$ & $\begin{array}{l}5 \\
:\end{array}$ & $\begin{array}{c}- \\
- \\
-1.78 \\
-1.95 \\
-2.11\end{array}$ & $\begin{array}{l}- \\
5 \\
-\end{array}$ & $\begin{array}{c}- \\
- \\
- \\
-0.26 \\
-.34\end{array}$ & & $\begin{array}{l}.618 \\
.430 \\
.175 \\
.157 \\
.148 \\
.141\end{array}$ & $\begin{array}{l}195 \\
116 \\
41.3 \\
36.9 \\
34.6 \\
33.0\end{array}$ \\
\hline$Q_{4}$ & $\begin{array}{l}- \\
4.85(-5) \\
1.09(-10) \\
7.90(-13) \\
6.04(-14)\end{array}$ & $\begin{array}{l}- \\
- \\
1.00 \\
1.07 \\
1.39\end{array}$ & $\begin{array}{l}- \\
- \\
-\end{array}$ & $\begin{array}{l}- \\
4.57 \\
6.44 \\
7.46 \\
7.85\end{array}$ & : & $\begin{array}{c}- \\
- \\
- \\
1.11 \\
1.47\end{array}$ & $\begin{array}{l}\overline{-} \\
\overline{-} \\
\overline{-}\end{array}$ & $\begin{array}{l}- \\
- \\
-\end{array}$ & $\begin{array}{l}- \\
\overline{-} \\
-\end{array}$ & $\begin{array}{c}- \\
- \\
- \\
- \\
-.28\end{array}$ & & $\begin{array}{l}.719 \\
.482 \\
.172 \\
.160 \\
.150\end{array}$ & $\begin{array}{l}252 \\
136 \\
40.6 \\
37.5 \\
35.2\end{array}$ \\
\hline$Q_{5}$ & $\begin{array}{c}. \\
.0193 \\
7.16(-8) \\
6.34(-6)\end{array}$ & $\begin{array}{l}- \\
- \\
.96 \\
.96\end{array}$ & $\begin{array}{l}- \\
\overline{-}\end{array}$ & $\begin{array}{l}- \\
2.88 \\
4.69 \\
4.15\end{array}$ & $\begin{array}{c}- \\
- \\
-0.89\end{array}$ & $\begin{array}{l}- \\
\overline{-} \\
-\end{array}$ & $\begin{array}{l}- \\
- \\
-\end{array}$ & $\begin{array}{l}- \\
-\end{array}$ & $\begin{array}{l}- \\
\overline{-}\end{array}$ & $\begin{array}{l}- \\
- \\
-\end{array}$ & & $\begin{array}{l}.562 \\
.453 \\
.133 \\
.122\end{array}$ & $\begin{array}{c}169 \\
124 \\
31.0 \\
28.4\end{array}$ \\
\hline$Q_{6}$ & $\begin{array}{l}- \\
3.87 \\
7.30(-7)\end{array}$ & $\begin{array}{c}- \\
.65 \\
1.06\end{array}$ & - & $\begin{array}{l}\overline{-} \\
3.90\end{array}$ & $\overline{-}$ & - & - & $\overline{-}$ & $\overline{-}$ & $\overline{-}$ & & $\begin{array}{l}.544 \\
.443 \\
.154\end{array}$ & $\begin{array}{l}161 \\
120 \\
36.2\end{array}$ \\
\hline$a_{7}$ & $\begin{array}{l}5.48 \\
2.88(-6) \\
3.53(-4)\end{array}$ & $\begin{array}{l}. \\
.56 \\
.94 \\
.94\end{array}$ & $\begin{array}{l}\overline{-} \\
\overline{-} \\
\overline{-}\end{array}$ & $\begin{array}{l}- \\
- \\
3.64 \\
3.06\end{array}$ & $\begin{array}{c}- \\
- \\
-.95\end{array}$ & $\begin{array}{l}- \\
-\end{array}$ & $\overline{-}$ & $\begin{array}{l}- \\
-\end{array}$ & $\begin{array}{l}- \\
-\end{array}$ & $\begin{array}{l}- \\
\overline{-}\end{array}$ & & $\begin{array}{l}.498 \\
.419 \\
.158 \\
.148\end{array}$ & $\begin{array}{l}141 \\
113 \\
37.1 \\
34.7\end{array}$ \\
\hline$Q_{8}$ & $\begin{array}{l}- \\
1.01 \\
1.01(-6)\end{array}$ & $\begin{array}{c}- \\
.69 \\
1.06\end{array}$ & $\begin{array}{l}\overline{-} \\
\overline{-}\end{array}$ & $\begin{array}{c}- \\
3.48\end{array}$ & $\overline{-}$ & $\begin{array}{l}- \\
-\end{array}$ & - & $\overline{-}$ & - & $\begin{array}{l}- \\
-\end{array}$ & & $\begin{array}{l}.525 \\
.402 \\
.154\end{array}$ & $\begin{array}{l}152 \\
109 \\
36.2\end{array}$ \\
\hline
\end{tabular}


TABLE 7.-Summary of Central region regression relations:

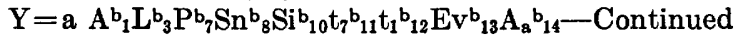

\begin{tabular}{|c|c|c|c|c|c|c|c|c|c|c|c|c|}
\hline Flow & Regression & & & & Regres & Sion C & fici & st & & & $\begin{array}{l}S \operatorname{stand} \\
F r \ln \end{array}$ & \\
\hline $\begin{array}{c}\text { Index } \\
\text { Y }\end{array}$ & $\begin{array}{c}\text { Constant } \\
a^{*}\end{array}$ & A & L & $P$ & $\mathrm{sn}$ & $\mathrm{Si}$ & $t_{7}$ & $t$ & $\mathrm{Ev}$ & $A_{a}$ & Logs & क \\
\hline$Q_{9}$ & $\begin{array}{l}- \\
0.0110 \\
9.58(-9) \\
2.45(-6)\end{array}$ & $\begin{array}{c}- \\
1.08 \\
1.07\end{array}$ & $\begin{array}{l}- \\
\overline{-}\end{array}$ & $\begin{array}{l}2.86 \\
4.87 \\
4.20\end{array}$ & $\begin{array}{c}- \\
- \\
-1.10\end{array}$ & $\begin{array}{l}\overline{-} \\
\overline{-}\end{array}$ & $\overline{-}$ & 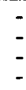 & $\overline{-}$ & $=$ & $\begin{array}{r}0.613 \\
.518 \\
.186 \\
.175\end{array}$ & $\begin{array}{c}193 \\
149 \\
44.1 \\
41.3\end{array}$ \\
\hline $\mathrm{SD}_{\mathrm{a}}$ & $\begin{array}{c}- \\
.0288 \\
7.20(-8) \\
1.73(-5)\end{array}$ & $\begin{array}{c}- \\
1.00 \\
.99\end{array}$ & $\begin{array}{l}- \\
\overline{-}\end{array}$ & $\begin{array}{c}- \\
2.57 \\
4.43 \\
3.77\end{array}$ & $\begin{array}{c}- \\
- \\
-1.09\end{array}$ & :- & $\overline{-}$ & $\begin{array}{l}- \\
-\end{array}$ & ! & ! & $\begin{array}{l}.557 \\
.473 \\
.155 \\
.144\end{array}$ & $\begin{array}{c}166 \\
133 \\
36.4 \\
33.0\end{array}$ \\
\hline $\mathrm{SD}_{10}$ & $\begin{array}{c}- \\
.0229 \\
1.34(-7)\end{array}$ & $\begin{array}{l}- \\
.93\end{array}$ & : & $\begin{array}{l}- \\
2.80 \\
4.54\end{array}$ & $\overline{-}$ & $\overline{-}$ & : & - & $\overline{-}$ & $\overline{-}$ & $\begin{array}{l}.562 \\
.461 \\
.197\end{array}$ & $\begin{array}{l}169 \\
127 \\
46.8\end{array}$ \\
\hline $\mathrm{SD}_{11}$ & $\begin{array}{l}5.30(-6) \\
6.38(-12)\end{array}$ & $\begin{array}{l}\overline{-} \\
1.05\end{array}$ & :- & $\begin{array}{l}5.08 \\
7.05\end{array}$ & $\overline{-}$ & : & 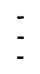 & $\overline{-}$ & $\overline{-}$ & : & $\begin{array}{l}.776 \\
.501 \\
.166\end{array}$ & $\begin{array}{l}291 \\
144 \\
39.3\end{array}$ \\
\hline $\mathrm{SD}_{12}$ & $\begin{array}{l}- \\
2.02(-6) \\
4.11(-11) \\
7.84(-9)\end{array}$ & $\begin{array}{l}- \\
-83 \\
.83\end{array}$ & $\begin{array}{l}- \\
-\end{array}$ & $\begin{array}{l}5.26 \\
6.82 \\
6.18\end{array}$ & $\begin{array}{l}- \\
- \\
-\end{array}$ & $\begin{array}{c}- \\
- \\
-1.04\end{array}$ & $\overline{-}$ & I & $\bar{z}$ & $\overline{-}$ & $\begin{array}{l}.745 \\
.418 \\
.187 \\
.178\end{array}$ & $\begin{array}{l}268 \\
112 \\
44.5 \\
42.0\end{array}$ \\
\hline$S D_{1}$ & $\begin{array}{l}- \\
1.53(-6) \\
5.70(-12) \\
2.33(-11)\end{array}$ & $\begin{array}{c}- \\
.96 \\
1.18\end{array}$ & $\begin{array}{c}= \\
- \\
-0.38\end{array}$ & $\begin{array}{l}5.34 \\
7.14 \\
6.82\end{array}$ & $\overline{-}$ & $\begin{array}{l}\overline{-} \\
\overline{-}\end{array}$ & $\overline{-}$ & - & $\overline{-}$ & $\overline{-}$ & $\begin{array}{l}.776 \\
.461 \\
.159 \\
.151\end{array}$ & $\begin{array}{l}290 \\
128 \\
37.3 \\
35.5\end{array}$ \\
\hline $\mathrm{SD}_{2}$ & $\begin{array}{l}6.00(-5) \\
3.12(-11)\end{array}$ & $\begin{array}{l}\overline{1} \\
1.12\end{array}$ & - & $\begin{array}{l}4.37 \\
6.45\end{array}$ & : & 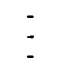 & $\overline{-}$ & $=$ & ! & : & $\begin{array}{l}.746 \\
.546 \\
.218\end{array}$ & $\begin{array}{l}269 \\
161.2 \\
52.3\end{array}$ \\
\hline $\mathrm{SD}_{3}$ & $\begin{array}{c}-.00141 \\
1.40(-8)\end{array}$ & $\begin{array}{l}- \\
-89\end{array}$ & : & $\begin{array}{r}-. \\
3.56 \\
5.22\end{array}$ & - & - & $\overline{-}$ & - & - & - & $\begin{array}{l}.623 \\
.466 \\
.243\end{array}$ & $\begin{array}{c}198 \\
130 \\
58.8\end{array}$ \\
\hline $\mathrm{SD}_{4}$ & $\begin{array}{l}- \\
2.34(-6) \\
2.24(-12) \\
1.30(-11) \\
1.37(-9)\end{array}$ & $\begin{array}{c}- \\
- \\
1.07 \\
1.35 \\
1.32\end{array}$ & $\begin{array}{c}- \\
- \\
-.51 \\
-.45\end{array}$ & $\begin{array}{c}- \\
5.56 \\
7.56 \\
7.14 \\
6.60\end{array}$ & $\begin{array}{c}- \\
-.96\end{array}$ & $\begin{array}{l}- \\
- \\
-\end{array}$ & 5 & $\overline{-}$ & 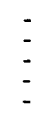 & $\begin{array}{l}- \\
- \\
-\end{array}$ & $\begin{array}{l}.830 \\
.515 \\
.188 \\
.177 \\
.168\end{array}$ & $\begin{array}{c}330 \\
149 \\
44.6 \\
41.8 \\
39.6\end{array}$ \\
\hline $\mathrm{SD}_{5}$ & $\begin{array}{c}-0456 \\
2.20(-7) \\
9.12(-5)\end{array}$ & $\begin{array}{l}- \\
.94 \\
.94\end{array}$ & $\overline{-}$ & $\begin{array}{c}- \\
2.67 \\
4.44 \\
3.71\end{array}$ & $\begin{array}{c}- \\
- \\
-1.20\end{array}$ & $\begin{array}{l}\bar{z} \\
\end{array}$ & $\begin{array}{l}- \\
\overline{-} \\
-\end{array}$ & - & $=$ & $\begin{array}{l}- \\
\overline{-}\end{array}$ & $\begin{array}{l}.544 \\
.450 \\
.150 \\
.131\end{array}$ & $\begin{array}{l}161 \\
123 \\
35.2 \\
30.6\end{array}$ \\
\hline $\mathrm{SD}_{6}$ & $\begin{array}{l}- \\
5.27 \\
2.84(-6)\end{array}$ & $\begin{array}{r}- \\
.64 \\
1.03\end{array}$ & : & $\begin{array}{c}- \\
- \\
3.63\end{array}$ & $=$ & $=$ & $\overline{-}$ & - & $\overline{-}$ & I & $\begin{array}{l}.538 \\
.436 \\
.202\end{array}$ & $\begin{array}{c}157 \\
118 \\
48.0\end{array}$ \\
\hline $\mathrm{SD}_{7}$ & $\begin{array}{l}- \\
3.98 \\
1.27(-6) \\
.000832\end{array}$ & $\begin{array}{l}- \\
-94 \\
.94\end{array}$ & :- & $\begin{array}{c}- \\
2.32 \\
4.08 \\
3.30\end{array}$ & $\begin{array}{c}- \\
- \\
-1.29\end{array}$ & $\overline{-}$ & : & - & - & $\overline{-}$ & $\begin{array}{l}.548 \\
.481 \\
.231 \\
.219\end{array}$ & $\begin{array}{l}162 \\
135 \\
55.7 \\
52.6\end{array}$ \\
\hline $\mathrm{SD}_{8}$ & $\begin{array}{l}-.82 \\
1.824 \\
.000170\end{array}$ & $\begin{array}{r}- \\
.67 \\
1.06 \\
1.06\end{array}$ & $\overline{-}$ & $\begin{array}{c}- \\
3.69 \\
3.06\end{array}$ & $\begin{array}{c}- \\
- \\
-1.07\end{array}$ & : & 5 & $=$ & $\begin{array}{l}- \\
\overline{-}\end{array}$ & 5 & $\begin{array}{l}.545 \\
.436 \\
.188 \\
.178\end{array}$ & $\begin{array}{l}161 \\
118 \\
44.7 \\
42.1\end{array}$ \\
\hline $\mathrm{SD}_{9}$ & $\begin{array}{c}-.0139 \\
3.62(-8)\end{array}$ & $\begin{array}{l}- \\
.99\end{array}$ & $\overline{-}$ & $\begin{array}{l}- \\
2.97 \\
4.82\end{array}$ & $\overline{-}$ & : & $=$ & - & - & $\overline{-}$ & $\begin{array}{l}.586 \\
.476 \\
.267\end{array}$ & $\begin{array}{c}180 \\
133 \\
39.3\end{array}$ \\
\hline
\end{tabular}


TABLE 7.-Summary of Central region regression relations:

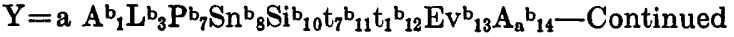

\begin{tabular}{|c|c|c|c|c|c|c|c|c|c|c|c|c|c|}
\hline \multirow{2}{*}{$\begin{array}{l}\text { Flow } \\
\text { Index } \\
Y\end{array}$} & \multirow{2}{*}{$\begin{array}{c}\text { Regression } \\
\text { Constant } \\
a^{*}\end{array}$} & \multicolumn{10}{|c|}{ Regression Coefficients for } & \multicolumn{2}{|c|}{$\begin{array}{l}\text { Standard } \\
\text { Error }\end{array}$} \\
\hline & & A & L & $\mathbf{P}$ & $\mathrm{Sn}$ & Si & $t_{7}$ & $t_{1}$ & Ev & $A_{a}$ & - & $\frac{\operatorname{Err}}{\log s}$ & 6 \\
\hline $\mathrm{g}_{\mathrm{a}}$ & $\begin{array}{l}- \\
0.00467 \\
.00860 \\
.0111\end{array}$ & $\begin{array}{c}- \\
- \\
- \\
-0.25\end{array}$ & - & $\begin{array}{l}- \\
- \\
-\end{array}$ & $\begin{array}{l}- \\
- \\
-\end{array}$ & - & $\begin{array}{l}- \\
- \\
-\end{array}$ & $\begin{array}{l}- \\
- \\
-\end{array}$ & $\begin{array}{l}- \\
1.58 \\
1.32 \\
1.46\end{array}$ & $\begin{array}{c}- \\
- \\
0.10 \\
.30\end{array}$ & & $\begin{array}{r}0.168 \\
.149 \\
.141 \\
.133\end{array}$ & $\begin{array}{l}37.0 \\
35.0 \\
33.0 \\
31.2\end{array}$ \\
\hline $\mathrm{SR}_{\mathrm{a}}$ & $\begin{array}{l}- \\
.199 \\
.0794 \\
3.86(4)\end{array}$ & $\begin{array}{l}\overline{-} \\
\overline{-}\end{array}$ & - & $\begin{array}{l}\text { - } \\
\text { - }\end{array}$ & $\begin{array}{l}- \\
- \\
-\end{array}$ & - & $\begin{array}{c}- \\
- \\
-2.91\end{array}$ & $\begin{array}{r}- \\
0.61 \\
.82 \\
.85\end{array}$ & - & $\begin{array}{l}- \\
- \\
.07 \\
.08\end{array}$ & & $\begin{array}{l}.078 \\
.064 \\
.052 \\
.050\end{array}$ & $\begin{array}{l}17.7 \\
14.7 \\
12.1 \\
11.6\end{array}$ \\
\hline
\end{tabular}

* Number in ( ) is power of 10 by which value must be multiplied.

TABLE 8.-Summary of Southern region regression relations:

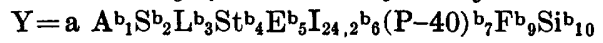

[All regression coefficients are statistically significant at the 5 percent level]

\begin{tabular}{|c|c|c|c|c|c|c|c|c|c|c|c|c|c|}
\hline \multirow{2}{*}{$\begin{array}{l}\text { Flow } \\
\text { Index } \\
Y\end{array}$} & \multirow{2}{*}{$\begin{array}{c}\text { Regression } \\
\text { Constant } \\
a^{*} \\
\end{array}$} & \multicolumn{10}{|c|}{ Regression Coefficients for } & \multicolumn{2}{|c|}{$\begin{array}{c}\text { Standard } \\
\text { Error }\end{array}$} \\
\hline & & A & $\mathbf{S}$ & L & st & $\mathbf{E}$ & $I_{24,2}$ & $P-40$ & $\mathrm{~F}$ & $\mathrm{Si}$ & - & logs & \% \\
\hline$P_{50}$ & $\begin{array}{l}1680^{-} \\
281^{-}\end{array}$ & $\begin{array}{c}- \\
0.52 \\
.67\end{array}$ & $\begin{array}{c}- \\
- \\
0.59\end{array}$ & - & - & - & - & - & - & $\begin{array}{l}- \\
-\end{array}$ & & $\begin{array}{r}0.373 \\
.219 \\
.179\end{array}$ & $\begin{array}{l}96.8 \\
52.5 \\
42.3\end{array}$ \\
\hline$P_{25}$ & $\begin{array}{c}1340^{-} \\
259^{-}\end{array}$ & $\begin{array}{l}- \\
.51 \\
.66\end{array}$ & $\begin{array}{l}- \\
- \\
.54\end{array}$ & $\begin{array}{l}- \\
-\end{array}$ & $=$ & $\overline{-}$ & - & - & $\begin{array}{l}- \\
-\end{array}$ & - & & $\begin{array}{l}.364 \\
.207 \\
.171\end{array}$ & $\begin{array}{l}94.0 \\
49.4 \\
40.3\end{array}$ \\
\hline$P_{10}$ & $\begin{array}{l}838^{-} \\
177^{-}\end{array}$ & $\begin{array}{l}- \\
.54 \\
.67\end{array}$ & $\begin{array}{l}- \\
.51\end{array}$ & $\begin{array}{l}- \\
-\end{array}$ & $\overline{-}$ & - & - & :- & $\overline{-}$ & $\begin{array}{l}- \\
-\end{array}$ & & $\begin{array}{l}.371 \\
.198 \\
.165\end{array}$ & $\begin{array}{l}96.2 \\
47.1 \\
38.7\end{array}$ \\
\hline$P_{5}$ & $\begin{array}{l}576 \\
145 \\
.77\end{array}$ & $\begin{array}{l}- \\
.54 \\
.66 \\
.70\end{array}$ & $\begin{array}{l}- \\
- \\
.45 \\
.52\end{array}$ & $\begin{array}{l}- \\
- \\
-\end{array}$ & $\begin{array}{c}- \\
- \\
-0.35\end{array}$ & - & $\begin{array}{l}- \\
- \\
3.16\end{array}$ & $\begin{array}{l}- \\
- \\
-\end{array}$ & $\begin{array}{l}- \\
- \\
-\end{array}$ & $\begin{array}{l}- \\
-\end{array}$ & & $\begin{array}{l}.376 \\
.200 \\
.175 \\
.164\end{array}$ & $\begin{array}{l}97.3 \\
47.5 \\
41.3 \\
38.6\end{array}$ \\
\hline$P_{2}$ & $\begin{array}{l}270 \\
106 \\
.19 \\
.076\end{array}$ & $\begin{array}{l}. \\
.56 \\
.64 \\
.68 \\
.70\end{array}$ & $\begin{array}{l}. \\
. \\
.31 \\
.41 \\
.40\end{array}$ & $\begin{array}{l}- \\
- \\
- \\
-\end{array}$ & $\begin{array}{l}- \\
- \\
- \\
- \\
-.46\end{array}$ & $\begin{array}{l}- \\
- \\
-\end{array}$ & $\begin{array}{l}- \\
- \\
- \\
3.74 \\
4.36\end{array}$ & $\begin{array}{l}- \\
- \\
- \\
-\end{array}$ & $\begin{array}{l}- \\
- \\
-\end{array}$ & - & & $\begin{array}{l}.386 \\
.201 \\
.191 \\
.182 \\
.170\end{array}$ & $\begin{array}{l}101 \\
47.8 \\
45.3 \\
43.1 \\
40.1\end{array}$ \\
\hline$P_{1.2}$ & $\begin{array}{l}109^{-} \\
.086 \\
.029\end{array}$ & $\begin{array}{l}- \\
.58 \\
.59 \\
.61\end{array}$ & $\begin{array}{l}- \\
- \\
-\end{array}$ & $\begin{array}{l}- \\
- \\
-\end{array}$ & $\begin{array}{c}- \\
- \\
- \\
-.47\end{array}$ & - & $\begin{array}{c}- \\
- \\
4.45 \\
5.14\end{array}$ & $\begin{array}{l}- \\
\overline{-} \\
-\end{array}$ & $\begin{array}{l}- \\
- \\
-\end{array}$ & - & & $\begin{array}{l}.399 \\
.208 \\
.194 \\
.182\end{array}$ & $\begin{array}{c}105 \\
49.7 \\
46.1 \\
43.1\end{array}$ \\
\hline$v_{3,50}$ & $\begin{array}{c}147^{-} \\
1.96\end{array}$ & $\begin{array}{l}. \\
.83 \\
.83\end{array}$ & - & $\begin{array}{l}- \\
-\end{array}$ & - & $\overline{-}$ & $\begin{array}{c}- \\
2.69\end{array}$ & $\begin{array}{l}- \\
-\end{array}$ & - & - & & $\begin{array}{l}.507 \\
.140 \\
.133\end{array}$ & $\begin{array}{r}144 \\
32.8 \\
31.1\end{array}$ \\
\hline$v_{3,20}$ & ${ }_{2.82}$ & $\begin{array}{l}. \\
.84 \\
.85\end{array}$ & $\begin{array}{l}- \\
-\end{array}$ & - & - & - & $\begin{array}{c}- \\
- \\
2.26\end{array}$ & - & - & $\dot{-}$ & & $\begin{array}{l}.510 \\
.121 \\
.116\end{array}$ & $\begin{array}{r}146 \\
28.2 \\
27.0\end{array}$ \\
\hline$v_{3,10}$ & $\begin{array}{c}- \\
79.9 \\
3.12\end{array}$ & $\begin{array}{l}. \\
.85 \\
.86\end{array}$ & $\begin{array}{l}- \\
-\end{array}$ & - & - & - & $\begin{array}{c}- \\
- \\
2.02\end{array}$ & $\begin{array}{l}- \\
-\end{array}$ & - & - & & $\begin{array}{l}.516 \\
.119 \\
.114\end{array}$ & $\begin{array}{r}148 \\
27.7 \\
26.6\end{array}$ \\
\hline$v_{3,2}$ & $\begin{array}{c}- \\
29.6 \\
.63 \\
47.9 \\
36.0 \\
\end{array}$ & $\begin{array}{l}- \\
.88 \\
.89 \\
.90 \\
.68 \\
\end{array}$ & $\begin{array}{l}- \\
- \\
- \\
\end{array}$ & $\begin{array}{l}- \\
- \\
- \\
0.40\end{array}$ & $\begin{array}{l}- \\
- \\
- \\
-\end{array}$ & - & $\begin{array}{c}- \\
2.40 \\
- \\
-\end{array}$ & $\begin{array}{l}- \\
- \\
-\end{array}$ & $\begin{array}{c}- \\
- \\
- \\
-0.14 \\
-.12 \\
\end{array}$ & - & & $\begin{array}{l}.536 \\
.133 \\
.127 \\
.124 \\
.119 \\
\end{array}$ & $\begin{array}{l}157 \\
31.1 \\
29.7 \\
28.9 \\
27.5 \\
\end{array}$ \\
\hline
\end{tabular}


TABLE 8.-Summary of Southern region regression relations:

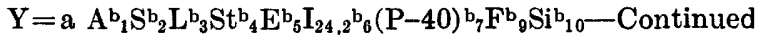

\begin{tabular}{|c|c|c|c|c|c|c|c|c|c|c|c|c|c|}
\hline \multirow{2}{*}{$\begin{array}{l}\text { Flow } \\
\text { Index } \\
\text { I }\end{array}$} & \multirow{2}{*}{$\begin{array}{c}\text { Regression } \\
\text { Constant } \\
\text { a* }\end{array}$} & \multicolumn{12}{|c|}{ Regression Coefficients for } \\
\hline & & A & $\mathrm{s}$ & $\mathrm{L}$ & st & E & $I_{24,2}$ & P-40 & $\mathrm{F}$ & $\mathrm{Si}$ & & $\operatorname{sir}$ & क \\
\hline$v_{7,50}$ & $\begin{array}{l}70.1 \\
.391\end{array}$ & $\begin{array}{r}0.86 \\
.87\end{array}$ & 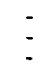 & - & $\overline{-}$ & - & $\begin{array}{c}- \\
- \\
3.23\end{array}$ & 5 & : & : & & $\begin{array}{r}0.522 \\
.128 \\
.115\end{array}$ & $\begin{array}{r}151 \\
29.9 \\
26.8\end{array}$ \\
\hline $\mathrm{v}_{7,20}$ & $\begin{array}{l}48.8 \\
.72\end{array}$ & $\begin{array}{l}.89 \\
.90\end{array}$ & : & 5 & $\vdots$ & - & $\begin{array}{c}- \\
2.63\end{array}$ & 5 & $\overline{-}$ & : & & $\begin{array}{l}.534 \\
.104 \\
.089\end{array}$ & $\begin{array}{l}156 \\
24.1 \\
20.7\end{array}$ \\
\hline$v_{7,10}$ & $\begin{array}{c}-. \\
35.7 \\
.93\end{array}$ & $\begin{array}{l}. \\
.91 \\
.92\end{array}$ & : & $\overline{-}$ & $\overline{-}$ & : & $\begin{array}{c}- \\
2.27\end{array}$ & 5 & $\overline{-}$ & $\overline{-}$ & & $\begin{array}{l}.545 \\
.097 \\
.089\end{array}$ & $\begin{array}{l}161 \\
22.5 \\
20.8\end{array}$ \\
\hline$v_{7,2}$ & $\begin{array}{r}- \\
12.6 \\
.382 \\
.224\end{array}$ & $\begin{array}{l}. \\
.97 \\
.97 \\
.98\end{array}$ & $\overline{-}$ & 5 & $\begin{array}{c}- \\
- \\
-0.23\end{array}$ & 5 & $\begin{array}{l}- \\
2.18 \\
2.52\end{array}$ & $\overline{-}$ & $:$ & I & & $\begin{array}{l}.579 \\
.105 \\
.098 \\
.093\end{array}$ & $\begin{array}{c}176 \\
24.4 \\
22.7 \\
21.5\end{array}$ \\
\hline$D_{10}$ & $\begin{array}{r}- \\
1.45 \\
.26 \\
.68 \\
.80\end{array}$ & $\begin{array}{l}- \\
1.13 \\
1.11 \\
1.05 \\
1.06\end{array}$ & $\begin{array}{c}\vdots \\
\vdots \\
-0.25 \\
-.21\end{array}$ & $\begin{array}{l}- \\
5\end{array}$ & $\begin{array}{l}\overline{-} \\
\overline{-}\end{array}$ & E & 5 & $\begin{array}{c}- \\
- \\
0.64 \\
.56 \\
.57\end{array}$ & $\begin{array}{l}\overline{-} \\
\overline{-}\end{array}$ & $\begin{array}{c}- \\
- \\
- \\
-0.25\end{array}$ & & $\begin{array}{l}.679 \\
.139 \\
.124 \\
.113 \\
.108\end{array}$ & $\begin{array}{l}228 \\
32.7 \\
28.9 \\
26.3 \\
25.2\end{array}$ \\
\hline $\mathrm{D}_{50}$ & $\begin{array}{l}7.14(-2) \\
5.63(-4) \\
2.31(-5) \\
1.51(-5)\end{array}$ & $\begin{array}{l}1.28 \\
1.22 \\
1.43 \\
1.39\end{array}$ & $\begin{array}{l}: \\
: .81 \\
.71\end{array}$ & $\begin{array}{l}5 \\
\end{array}$ & $\begin{array}{l}\overline{-} \\
\overline{-}\end{array}$ & $\overline{-}$ & $\bar{z}$ & $\begin{array}{c}- \\
- \\
1.80 \\
2.07 \\
2.06\end{array}$ & $\begin{array}{l}- \\
\overline{-} \\
\overline{-}\end{array}$ & $\begin{array}{l}5 \\
5 \\
.66\end{array}$ & & $\begin{array}{l}.840 \\
.875 \\
.329 \\
.281 \\
.268\end{array}$ & $\begin{array}{c}339 \\
97.4 \\
83.2 \\
69.1 \\
65.6\end{array}$ \\
\hline$D_{90}$ & $\begin{array}{l}8.05(-3) \\
1.06(-9) \\
1.54(-13)\end{array}$ & $\begin{array}{l}- \\
1.31 \\
1.11 \\
1.68\end{array}$ & $\begin{array}{l}- \\
- \\
2.24\end{array}$ & $\overline{-}$ & : & : & : & $\begin{array}{c}- \\
5.89 \\
6.64\end{array}$ & $\begin{array}{l}- \\
\overline{-}\end{array}$ & 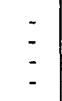 & & $\begin{array}{r}1.221 \\
.958 \\
.747 \\
.569\end{array}$ & $\begin{array}{l}830 \\
448 \\
270 \\
172\end{array}$ \\
\hline$M_{7,2}$ & $\begin{array}{l}2.26(-3) \\
2.39(-11) \\
9.20(-17)\end{array}$ & $\begin{array}{l}1.48 \\
1.24 \\
2.05\end{array}$ & $\begin{array}{l}- \\
5 \\
3.16\end{array}$ & $\overline{-}$ & $\overline{-}$ & $\overline{-}$ & : & $\begin{array}{c}- \\
6.82 \\
7.88\end{array}$ & $\begin{array}{l}\overline{-} \\
\overline{-}\end{array}$ & $\begin{array}{l}\overline{-} \\
-\end{array}$ & & $\begin{array}{r}1.465 \\
1.194 \\
.975 \\
.693\end{array}$ & $\begin{array}{r}1460 \\
780 \\
467 \\
236\end{array}$ \\
\hline$M_{7,20}$ & $\begin{array}{l}9.42(-14) \\
1.14(-14) \\
1.51(-21)\end{array}$ & $\begin{array}{c}- \\
1.06 \\
2.08\end{array}$ & $\begin{array}{l}= \\
\overline{4.01}\end{array}$ & - & $\begin{array}{l}\overline{-} \\
\overline{-}\end{array}$ & E & : & $\begin{array}{r}- \\
10.50 \\
9.34 \\
10.70\end{array}$ & $\overline{-}$ & $\begin{array}{l}- \\
\overline{-}\end{array}$ & & $\begin{array}{r}1.798 \\
1.445 \\
1.320 \\
.995\end{array}$ & $\begin{array}{r}3140 \\
1390 \\
1040 \\
490\end{array}$ \\
\hline$Q_{a}$ & $\begin{array}{r}-. \\
1.09 \\
.23\end{array}$ & $\begin{array}{l}- \\
1.04 \\
1.02\end{array}$ & $:$ & : & $\overline{-}$ & $\overline{-}$ & : & $\begin{array}{l}- \\
.58\end{array}$ & $\overline{-}$ & $\overline{-}$ & & $\begin{array}{l}.619 \\
.080 \\
.054\end{array}$ & $\begin{array}{c}196 \\
18.6 \\
12.6\end{array}$ \\
\hline$Q_{10}$ & $\begin{array}{l}- \\
.27 \\
.0082 \\
.0056\end{array}$ & $\begin{array}{l}-. \\
1.04 \\
.99 \\
1.23\end{array}$ & $\begin{array}{l}5 \\
.72\end{array}$ & : & $=$ & $=$ & : & $\begin{array}{l}- \\
- \\
1.30 \\
1.14\end{array}$ & $\begin{array}{c}- \\
- \\
-0.41\end{array}$ & $\begin{array}{l}- \\
-\end{array}$ & & $\begin{array}{l}.681 \\
.307 \\
.280 \\
.259\end{array}$ & $\begin{array}{c}229 \\
76.8 \\
68.9 \\
63.3\end{array}$ \\
\hline$a_{11}$ & $\begin{array}{l}-.840 \\
.021 \\
.0088\end{array}$ & $\begin{array}{r}-. \\
1.00 \\
.96 \\
1.01\end{array}$ & $\begin{array}{l}- \\
. \\
.22\end{array}$ & 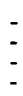 & 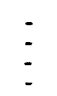 & ; & : & $\begin{array}{c}- \\
1.38 \\
1.45\end{array}$ & $\begin{array}{l}5 \\
\vdots\end{array}$ & : & & $\begin{array}{l}.621 \\
.195 \\
.135 \\
.128\end{array}$ & $\begin{array}{r}197 \\
46.4 \\
31.6 \\
29.9\end{array}$ \\
\hline$Q_{12}$ & $\begin{array}{l}1.25 \\
.060 \\
.094\end{array}$ & $\begin{array}{r}-.02 \\
1.02 \\
.98 \\
.99\end{array}$ & $\begin{array}{l}\overline{-} \\
\overline{-}\end{array}$ & : & $=$ & - & $\begin{array}{l}- \\
\overline{-}\end{array}$ & $\begin{array}{l}- \\
- \\
1.13 \\
1.11\end{array}$ & 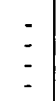 & $\begin{array}{c}- \\
- \\
-.35\end{array}$ & & $\begin{array}{l}.622 \\
.161 \\
.111 \\
.100\end{array}$ & $\begin{array}{c}197 \\
37.7 \\
25.9 \\
23.2\end{array}$ \\
\hline$Q_{1}$ & $\begin{array}{c}- \\
1.70 \\
2.46 \\
\end{array}$ & $\begin{array}{l}- \\
1.04 \\
1.06\end{array}$ & 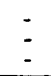 & $\overline{-}$ & $\overline{-}$ & 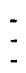 & $\vdots$ & I & $\begin{array}{c}- \\
-.12 \\
-.12\end{array}$ & $=$ & & $\begin{array}{l}.619 \\
.071 \\
.059\end{array}$ & $\begin{array}{c}196 \\
16.5 \\
13.6\end{array}$ \\
\hline
\end{tabular}


TABLE 8.-Summary of Southern region regression relations:

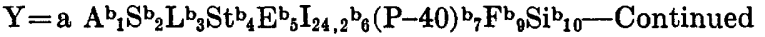

\begin{tabular}{|c|c|c|c|c|c|c|c|c|c|c|c|c|c|}
\hline \multirow{2}{*}{$\begin{array}{l}\text { Flow } \\
\text { Index } \\
y\end{array}$} & \multirow{2}{*}{$\begin{array}{c}\text { Regression } \\
\text { Constant } \\
a^{*}\end{array}$} & \multicolumn{10}{|c|}{ Regression Coefficients for } & \multicolumn{2}{|c|}{$\begin{array}{l}\text { Standard } \\
\text { Error }\end{array}$} \\
\hline & & A & $s$ & $\mathrm{~L}$ & St & $\mathrm{E}$ & $I_{24,2}$ & $P-40$ & $\mathrm{~F}$ & 51 & - & \begin{tabular}{|l}
$\log s$ \\
\end{tabular} & $\%$ \\
\hline$a_{2}$ & $\begin{array}{r}- \\
2.24 \\
.81\end{array}$ & $\begin{array}{c}- \\
1.03 \\
1.02\end{array}$ & $\overline{-}$ & $\overline{-}$ & - & $\begin{array}{l}- \\
-\end{array}$ & $\begin{array}{l}- \\
-\end{array}$ & $\begin{array}{c}- \\
-0.38\end{array}$ & $\begin{array}{l}- \\
-\end{array}$ & - & & $\begin{array}{r}0.611 \\
.073 \\
.062\end{array}$ & $\begin{array}{l}192 \\
16.8 \\
14.4\end{array}$ \\
\hline$Q_{3}$ & $\begin{array}{r}- \\
1.62 \\
.66 \\
.39\end{array}$ & $\begin{array}{c}- \\
1.07 \\
1.06 \\
1.09\end{array}$ & $\begin{array}{c}- \\
- \\
-0.14\end{array}$ & $\begin{array}{l}- \\
- \\
-\end{array}$ & $\begin{array}{l}- \\
-\end{array}$ & - & $\begin{array}{l}- \\
-\end{array}$ & $\begin{array}{c}- \\
- \\
-.33 \\
-.38\end{array}$ & $\begin{array}{l}- \\
- \\
-\end{array}$ & : & & $\begin{array}{l}.634 \\
.082 \\
.075 \\
.070\end{array}$ & $\begin{array}{r}203 \\
18.9 \\
17.3 \\
16.1\end{array}$ \\
\hline$Q_{4}$ & $\begin{array}{r}. \\
1.46 \\
1.16 \\
.59\end{array}$ & $\begin{array}{l}- \\
1.06 \\
1.05 \\
1.04\end{array}$ & $\begin{array}{l}- \\
- \\
-\end{array}$ & $\begin{array}{l}- \\
-\end{array}$ & $\begin{array}{l}- \\
-\end{array}$ & $\begin{array}{l}\overline{-} \\
\overline{-}\end{array}$ & $\begin{array}{l}- \\
-\end{array}$ & $\begin{array}{c}- \\
- \\
-.23\end{array}$ & $\begin{array}{c}- \\
- \\
0.07 \\
.09\end{array}$ & $\begin{array}{l}- \\
-\end{array}$ & & $\begin{array}{l}.628 \\
.064 \\
.059 \\
.055\end{array}$ & $\begin{array}{l}200 \\
14.8 \\
13.8 \\
12.8\end{array}$ \\
\hline$Q_{5}$ & 1.46 & $\begin{array}{c}- \\
1.05\end{array}$ & - & - & - & : & - & - & $\overline{-}$ & - & & $\begin{array}{l}.623 \\
.088\end{array}$ & $\begin{array}{l}198 \\
20.3\end{array}$ \\
\hline$a_{6}$ & $\begin{array}{l}- \\
.72 \\
.050 \\
.076\end{array}$ & $\begin{array}{c}.0 \\
1.04 \\
1.01 \\
1.01\end{array}$ & $\begin{array}{l}- \\
- \\
-\end{array}$ & $=$ & $\begin{array}{l}- \\
-\end{array}$ & $\begin{array}{l}\text { - } \\
\overline{-}\end{array}$ & : & $\begin{array}{c}- \\
-.99 \\
-.98\end{array}$ & $\begin{array}{l}- \\
\overline{-}\end{array}$ & $\begin{array}{c}\overline{-} \\
-0.34\end{array}$ & & $\begin{array}{l}.631 \\
.157 \\
.120 \\
.111\end{array}$ & $\begin{array}{r}202 \\
36.8 \\
27.9 \\
25.8\end{array}$ \\
\hline${ }^{Q_{7}}$ & $\begin{array}{l}- \\
.34 \\
.00026\end{array}$ & $\begin{array}{c}- \\
1.11 \\
1.01\end{array}$ & $\overline{-}$ & - & - & - & - & $\begin{array}{c}: \\
-2.68\end{array}$ & - & - & & $\begin{array}{r}.728 \\
.330 \\
.182\end{array}$ & $\begin{array}{l}258 \\
83.6 \\
43.1\end{array}$ \\
\hline$Q_{8}$ & $\begin{array}{l}- \\
.35 \\
.00034\end{array}$ & $\begin{array}{r}- \\
1.05 \\
.96\end{array}$ & - & - & $\overline{-}$ & - & $\overline{-}$ & $\begin{array}{c}- \\
- \\
-2.58\end{array}$ & - & - & & $\begin{array}{l}.716 \\
.366 \\
.254\end{array}$ & $\begin{array}{l}250 \\
94.7 \\
61.9\end{array}$ \\
\hline$Q_{9}$ & $\begin{array}{l}- \\
.41 \\
1.52(-4)\end{array}$ & $\begin{array}{r}- \\
1.00 \\
.90\end{array}$ & $\begin{array}{l}- \\
-\end{array}$ & : & - & - & - & $\begin{array}{c}- \\
-2.94\end{array}$ & $\overline{-}$ & - & & $\begin{array}{l}.706 \\
.395 \\
.254\end{array}$ & $\begin{array}{c}244 \\
104 \\
61.9\end{array}$ \\
\hline $\mathrm{SD}_{\mathrm{a}}$ & $-8 \mathrm{l}$ & -.95 & - & - & $\overline{-}$ & - & - & $=$ & - & - & & $\begin{array}{l}.560 \\
.062\end{array}$ & $\begin{array}{l}168 \\
14.5\end{array}$ \\
\hline $\mathrm{SD}_{10}$ & $\begin{array}{c}- \\
.50 \\
1.66 \\
35.5\end{array}$ & $\begin{array}{r}. \\
.93 \\
.97 \\
1.02\end{array}$ & : & $\begin{array}{l}= \\
=\end{array}$ & $\begin{array}{l}\overline{-} \\
-\end{array}$ & $\begin{array}{l}- \\
\overline{-}\end{array}$ & : & $\begin{array}{c}- \\
-1.04\end{array}$ & $\begin{array}{c}- \\
- \\
-.36 \\
-.44\end{array}$ & : & & $\begin{array}{l}.609 \\
.269 \\
.236 \\
.214\end{array}$ & $\begin{array}{r}191 \\
65.9 \\
57.0 \\
51.2\end{array}$ \\
\hline$S D_{11}$ & $\begin{array}{r}- \\
1.87 \\
.34\end{array}$ & $\begin{array}{l}. \\
.93 \\
.91\end{array}$ & - & : & : & - & - &.- & - & - & & $\begin{array}{l}.576 \\
.186 \\
.176\end{array}$ & $\begin{array}{c}175 \\
44.1 \\
41.6\end{array}$ \\
\hline $\mathrm{SD}_{12}$ & $\begin{array}{c}- \\
1.23 \\
.98\end{array}$ & $\begin{array}{r}- \\
1.03 \\
.80\end{array}$ & - & $\begin{array}{c}- \\
0.43\end{array}$ & - & - & - & $\vdots$ & $\vdots$ & : & & $\begin{array}{l}.616 \\
.125 \\
.119\end{array}$ & $\begin{array}{l}194 \\
29.2 \\
27.8\end{array}$ \\
\hline $\mathrm{SD}_{1}$ & $\begin{array}{c}- \\
1.93 \\
10.3 \\
29.7 \\
31.5 \\
35.5\end{array}$ & $\begin{array}{r}- \\
.99 \\
1.01 \\
.94 \\
.95 \\
.96\end{array}$ & $\begin{array}{l}- \\
- \\
- \\
-.27 \\
-.28 \\
-.26\end{array}$ & $\begin{array}{l}- \\
5 \\
5\end{array}$ & $\begin{array}{c}- \\
- \\
- \\
-0.25 \\
-.25\end{array}$ & $\begin{array}{l}- \\
\\
- \\
-\end{array}$ & $\begin{array}{l}- \\
- \\
- \\
-\end{array}$ & $\begin{array}{c}- \\
-.62 \\
-.72 \\
-.71 \\
-.71\end{array}$ & $\begin{array}{l}: \\
\vdots \\
-\end{array}$ & $\begin{array}{c}\vdots \\
\vdots \\
\vdots \\
-.17\end{array}$ & & $\begin{array}{l}.591 \\
.115 \\
.096 \\
.077 \\
.067 \\
.064\end{array}$ & $\begin{array}{c}182 \\
26.7 \\
22.2 \\
17.8 \\
15.6 \\
14.8\end{array}$ \\
\hline $\mathrm{SD}_{2}$ & $\begin{array}{l}.0 \\
.038 \\
.038\end{array}$ & $\begin{array}{l}- \\
.94 \\
.94\end{array}$ & - & 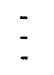 & - & $\begin{array}{l}- \\
-\end{array}$ & $\frac{-}{2.60}$ & : & 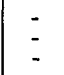 & $\overline{-}$ & & $\begin{array}{l}.561 \\
.103 \\
.092\end{array}$ & $\begin{array}{c}168 \\
23.9 \\
21.4\end{array}$ \\
\hline $\mathrm{SD}_{3}$ & $\begin{array}{l}- \\
1.68 \\
.020 \\
.0037 \\
.0066 \\
.017\end{array}$ & $\begin{array}{r}- \\
.98 \\
.99 \\
1.04 \\
.87 \\
.87\end{array}$ & $\begin{array}{c}- \\
- \\
- \\
-.18 \\
-.19 \\
-.21\end{array}$ & $\begin{array}{l}- \\
- \\
- \\
-31 \\
.32\end{array}$ & $\begin{array}{l}: \\
\vdots\end{array}$ & $\begin{array}{l}- \\
- \\
- \\
-\end{array}$ & $\begin{array}{c}- \\
2.77 \\
3.47 \\
3.00 \\
2.53\end{array}$ & $\begin{array}{l}5 \\
\vdots\end{array}$ & 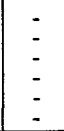 & $\begin{array}{l}- \\
- \\
- \\
- \\
-.21\end{array}$ & & $\begin{array}{l}.588 \\
.110 \\
.098 \\
.092 \\
.088 \\
.084\end{array}$ & $\begin{array}{r}181 \\
25.6 \\
22.8 \\
21.4 \\
20.5 \\
19.6\end{array}$ \\
\hline
\end{tabular}


TABLE 8.-Summary of Southern region regression relations: $\mathrm{Y}=\mathrm{a} \mathrm{A} \mathrm{b}_{1} \mathrm{~S}_{2} \mathrm{~L}_{3} \mathrm{St}_{4} \mathrm{E}_{5} \mathrm{I}_{24,2} \mathrm{~b}_{6}(\mathrm{P}-40) \mathrm{b}_{7} \mathrm{~F}_{9} \mathrm{Si}{ }_{10}$-Continued

\begin{tabular}{|c|c|c|c|c|c|c|c|c|c|c|c|c|c|}
\hline \multirow{2}{*}{$\begin{array}{c}\text { Flow } \\
\text { Index } \\
Y\end{array}$} & \multirow{2}{*}{$\begin{array}{c}\begin{array}{c}\text { Regression } \\
\text { Constant } \\
a^{*}\end{array} \\
\end{array}$} & \multicolumn{10}{|c|}{ Regression Coefficients for } & \multicolumn{2}{|c|}{$\begin{array}{l}\text { Standard } \\
\text { Error }\end{array}$} \\
\hline & & A & $s$ & I & st & $\mathrm{E}$ & $I_{24,2}$ & $P-40$ & F & $\mathrm{Si}$ & - & logs & $\%$ \\
\hline $\mathrm{SD}_{4}$ & $\begin{array}{r}. \\
1.43 \\
.12\end{array}$ & $\begin{array}{l}- \\
1.01 \\
1.01\end{array}$ & $\begin{array}{l}- \\
-\end{array}$ & - & $\begin{array}{l}- \\
-\end{array}$ & $\begin{array}{l}- \\
-\end{array}$ & $\begin{array}{c}- \\
1.52\end{array}$ & $\overline{-}$ & $\begin{array}{l}- \\
-\end{array}$ & $\begin{array}{l}- \\
\overline{-}\end{array}$ & & $\begin{array}{r}0.599 \\
.090 \\
.086\end{array}$ & $\begin{array}{l}186 \\
20.8 \\
20.0\end{array}$ \\
\hline $\mathrm{SD}_{5}$ & ${ }^{-} .75$ & -.98 & - & - & - & - & - & - & - & - & & $\begin{array}{l}.601 \\
.172\end{array}$ & ${ }_{40.6}^{187}$ \\
\hline $\mathrm{SD}_{6}$ & $\begin{array}{l}- \\
1.47 \\
2.62\end{array}$ & $\begin{array}{l}- \\
.93 \\
.94\end{array}$ & $\overline{-}$ & - & $\begin{array}{l}\overline{-} \\
\overline{-}\end{array}$ & - & - & - & $\overline{-}$ & $\begin{array}{c}- \\
- \\
-0.51\end{array}$ & & $\begin{array}{l}.577 \\
.185 \\
.172\end{array}$ & $\begin{array}{r}175 \\
43.8 \\
40.7\end{array}$ \\
\hline $\mathrm{SD}_{7}$ & $\begin{array}{l}- \\
.36 \\
.0026 \\
.045\end{array}$ & $\begin{array}{l}-. \\
1.10 \\
1.04 \\
1.07\end{array}$ & $\begin{array}{l}- \\
- \\
-\end{array}$ & $\begin{array}{l}- \\
-\end{array}$ & $\begin{array}{l}- \\
- \\
-\end{array}$ & $\begin{array}{c}= \\
= \\
-0.44\end{array}$ & $\begin{array}{l}- \\
\overline{-}\end{array}$ & $\begin{array}{c}- \\
- \\
1.84 \\
1.55\end{array}$ & - & $\begin{array}{l}- \\
- \\
-\end{array}$ & & $\begin{array}{l}.713 \\
.300 \\
.234 \\
.212\end{array}$ & $\begin{array}{r}248 \\
74.6 \\
56.5 \\
50.6\end{array}$ \\
\hline $\mathrm{SD}_{8}$ & $\begin{array}{l}- \\
.62 \\
8.18(-9) \\
1.02(-9)\end{array}$ & $\begin{array}{r}- \\
.98 \\
1.01 \\
1.56\end{array}$ & - & $\begin{array}{c}- \\
- \\
-1.02\end{array}$ & $\begin{array}{l}- \\
- \\
-\end{array}$ & $\begin{array}{l}- \\
\overline{-} \\
-\end{array}$ & $\begin{array}{c}- \\
- \\
11.3 \\
12.9\end{array}$ & $\begin{array}{l}\overline{-} \\
\overline{-}\end{array}$ & $\begin{array}{l}- \\
- \\
-\end{array}$ & $\begin{array}{l}- \\
- \\
=\end{array}$ & & $\begin{array}{l}.671 \\
.346 \\
.280 \\
.266\end{array}$ & $\begin{array}{l}224 \\
88.5 \\
68.9 \\
65.1\end{array}$ \\
\hline $\mathrm{SD}_{9}$ & $\begin{array}{l}- \\
1.07 \\
2.71(-6)\end{array}$ & $\begin{array}{l}- \\
.87 \\
.89\end{array}$ & - & - & $\overline{-}$ & - & $\begin{array}{c}- \\
8.03\end{array}$ & $\overline{-}$ & - & - & & $\begin{array}{l}.611 \\
.339 \\
.309\end{array}$ & $\begin{array}{r}192 \\
86.2 \\
77.3\end{array}$ \\
\hline
\end{tabular}

* Number in ( ) is power of 10 by which value must be multiplied.

\section{TABLE 9.-Summary of Western region regression relations: $\mathrm{Y}=\mathrm{a} \mathrm{A}^{\mathrm{b}}{ }_{1} \mathrm{~S}_{2} \mathrm{St}^{\mathrm{b}}{ }_{4} \mathrm{E}_{5} \mathrm{~b}_{24,2} \mathrm{I}_{6} \mathrm{~Pb}_{7} \mathrm{Sn}^{\mathrm{b}}{ }_{8} \mathrm{Fb}_{9} \mathrm{Si}^{\mathrm{b}}{ }_{10}$}

[All regression coefficients are statistically significant at the 5 percent level, except those preceded by $d$ ]

\begin{tabular}{|c|c|c|c|c|c|c|c|c|c|c|c|c|c|}
\hline \multirow{2}{*}{$\begin{array}{l}\text { Flow } \\
\text { Index } \\
Y \\
\end{array}$} & \multirow{2}{*}{$\begin{array}{c}\text { Regression } \\
\text { Constant } \\
a^{*}\end{array}$} & \multicolumn{10}{|c|}{ Regression Coefficients for } & \multicolumn{2}{|c|}{$\begin{array}{c}\text { Standard } \\
\text { Error }\end{array}$} \\
\hline & & A & $\mathbf{s}$ & St & $\mathrm{E}$ & $I_{24,2}$ & $P$ & Sn & F & Si & - & logs & $\%$ \\
\hline$P_{50}$ & $\begin{array}{c}- \\
21.5 \\
6.03 \\
2.31\end{array}$ & $\begin{array}{r}- \\
0.83 \\
.81 \\
.83\end{array}$ & - & $\overline{-}$ & $\begin{array}{c}- \\
- \\
-0.48\end{array}$ & $\begin{array}{l}- \\
-\end{array}$ & - & $\begin{array}{l}- \\
-\end{array}$ & $\begin{array}{c}- \\
- \\
0.84 \\
1.20\end{array}$ & $\begin{array}{l}- \\
-\end{array}$ & & $\begin{array}{r}0.485 \\
.262 \\
.236 \\
.191\end{array}$ & $\begin{array}{r}139 \\
64.0 \\
57.0 \\
45.3\end{array}$ \\
\hline$P_{25}$ & $\begin{array}{l}164^{-} \\
251^{2} \\
2.64\end{array}$ & $\begin{array}{l}- \\
.83 \\
.85 \\
.84\end{array}$ & $\begin{array}{l}- \\
- \\
-\end{array}$ & - & $\begin{array}{c}- \\
- \\
-.35 \\
-.53\end{array}$ & - & $\begin{array}{l}- \\
- \\
-\end{array}$ & $\begin{array}{l}- \\
-\end{array}$ & $\begin{array}{l}- \\
- \\
1.12\end{array}$ & $\begin{array}{l}- \\
-\end{array}$ & & $\begin{array}{l}.476 \\
.248 \\
.226 \\
.169\end{array}$ & $\begin{array}{r}133 \\
60.3 \\
54.4 \\
39.8\end{array}$ \\
\hline$P_{10}$ & $\begin{array}{l}128^{-} \\
200 \\
2.96 \\
.873\end{array}$ & $\begin{array}{l}. \\
.83 \\
.85 \\
.84 \\
.86\end{array}$ & $\begin{array}{l}- \\
- \\
-\end{array}$ & $\begin{array}{l}- \\
- \\
-\end{array}$ & $\begin{array}{c}- \\
- \\
-.37 \\
-.54 \\
-.66\end{array}$ & $\begin{array}{l}- \\
- \\
-\end{array}$ & $\begin{array}{c}- \\
- \\
- \\
- \\
0.50\end{array}$ & $\begin{array}{l}- \\
- \\
-\end{array}$ & $\begin{array}{c}- \\
- \\
1.03 \\
.90\end{array}$ & $\begin{array}{l}- \\
- \\
-\end{array}$ & & $\begin{array}{l}.472 \\
.241 \\
.215 \\
.164 \\
.157\end{array}$ & $\begin{array}{r}132 \\
58.4 \\
51.5 \\
38.6 \\
36.9\end{array}$ \\
\hline$P_{5}$ & $\begin{array}{r}93.9 \\
146 \\
3.40 \\
.677\end{array}$ & $\begin{array}{l}- \\
.83 \\
.85 \\
.84 \\
.87\end{array}$ & $\begin{array}{l}- \\
- \\
-\end{array}$ & $\begin{array}{l}- \\
- \\
- \\
-\end{array}$ & $\begin{array}{r}- \\
- \\
-.37 \\
-.51 \\
-.68\end{array}$ & $\begin{array}{l}- \\
\overline{-} \\
\overline{-}\end{array}$ & $\begin{array}{l}- \\
- \\
- \\
.66\end{array}$ & $\begin{array}{l}- \\
- \\
-\end{array}$ & $\begin{array}{l}- \\
- \\
- \\
.92 \\
.75\end{array}$ & $\begin{array}{l}- \\
- \\
-\end{array}$ & & $\begin{array}{l}.471 \\
.239 \\
.213 \\
.174 \\
.160\end{array}$ & $\begin{array}{r}131 \\
57.8 \\
51.0 \\
41.1 \\
37.6\end{array}$ \\
\hline$P_{2}$ & $\begin{array}{c}- \\
50.1 \\
67.1 \\
.633\end{array}$ & $\begin{array}{l}. \\
.83 \\
.85 \\
.90\end{array}$ & - & $\begin{array}{l}- \\
- \\
-\end{array}$ & $\begin{array}{r}- \\
- \\
d-.24 \\
-.63\end{array}$ & $\begin{array}{l}\overline{-} \\
\overline{-}\end{array}$ & $\begin{array}{l}- \\
- \\
1.33\end{array}$ & $\begin{array}{l}- \\
- \\
-\end{array}$ & $\begin{array}{l}- \\
- \\
-\end{array}$ & $\begin{array}{l}- \\
-\end{array}$ & & $\begin{array}{l}.481 \\
.256 \\
.248 \\
.199\end{array}$ & $\begin{array}{r}135 \\
62.4 \\
60.0 \\
48.0\end{array}$ \\
\hline
\end{tabular}


RESULTS

TABLE 9.-Summary of Western region regression relations:

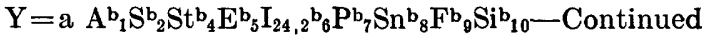

\begin{tabular}{|c|c|c|c|c|c|c|c|c|c|c|c|c|c|}
\hline \multirow{2}{*}{$\begin{array}{l}\text { Flow } \\
\text { Index } \\
\quad \mathrm{Y}\end{array}$} & \multirow{2}{*}{$\begin{array}{c}\text { Regression } \\
\text { Constant } \\
a^{*} \\
\end{array}$} & \multicolumn{10}{|c|}{ Regression Coefficients for } & \multicolumn{2}{|c|}{$\begin{array}{l}\text { Standard } \\
\text { Error }\end{array}$} \\
\hline & & A & $\mathrm{s}$ & St & $\mathrm{E}$ & $\mathrm{I}_{24,2}$ & $\mathbf{P}$ & Sn & $\mathrm{F}$ & Si & - & Logs & \% \\
\hline$P_{1.2}$ & $\begin{array}{l}16.1 \\
6.41(-3)\end{array}$ & $\begin{array}{r}-. \\
0.85 \\
.89\end{array}$ & - & $\begin{array}{l}- \\
-\end{array}$ & $\begin{array}{l}- \\
-\end{array}$ & $\begin{array}{l}- \\
-\end{array}$ & $\frac{-}{2.02}$ & $\begin{array}{l}- \\
-\end{array}$ & $\begin{array}{l}- \\
-\end{array}$ & $\begin{array}{l}- \\
-\end{array}$ & & $\begin{array}{r}0.637 \\
.488 \\
.394\end{array}$ & $\begin{array}{l}138^{-} \\
104^{-}\end{array}$ \\
\hline$v_{3,50}$ & $\begin{array}{c}- \\
81.1 \\
3.40 \\
1.74 \\
2.20\end{array}$ & $\begin{array}{l}- \\
.84 \\
.82 \\
.84 \\
.87\end{array}$ & $\begin{array}{l}- \\
\text { - } \\
\text { - }\end{array}$ & $\begin{array}{l}- \\
- \\
-\end{array}$ & $\begin{array}{c}- \\
- \\
-0.34 \\
-.55\end{array}$ & $\begin{array}{l}- \\
- \\
- \\
-\end{array}$ & $\begin{array}{l}- \\
- \\
- \\
.84\end{array}$ & $\begin{array}{l}- \\
- \\
- \\
-\end{array}$ & $\begin{array}{c}- \\
- \\
0.74 \\
1.00 \\
.78\end{array}$ & $\begin{array}{l}- \\
- \\
-\end{array}$ & & $\begin{array}{l}.469 \\
.225 \\
.201 \\
.176 \\
.152\end{array}$ & $\begin{array}{l}130 \\
54.1 \\
47.9 \\
41.6 \\
37.7\end{array}$ \\
\hline$v_{3,20}$ & $\begin{array}{c}- \\
61.2 \\
10.8 \\
1.64 \\
.296 \\
.0393\end{array}$ & $\begin{array}{l}. \\
.85 \\
.86 \\
.91 \\
.89 \\
.89\end{array}$ & $\begin{array}{l}- \\
\overline{-} \\
\overline{-} \\
-\end{array}$ & $\begin{array}{l}- \\
- \\
- \\
- \\
- \\
.63\end{array}$ & $\begin{array}{c}- \\
- \\
- \\
-.48 \\
-.51 \\
-.70\end{array}$ & $\begin{array}{l}- \\
- \\
- \\
-\end{array}$ & $\begin{array}{r}- \\
- \\
.45 \\
1.08 \\
.86 \\
.84\end{array}$ & $\begin{array}{l}- \\
\overline{-} \\
-\end{array}$ & $\begin{array}{c}- \\
- \\
- \\
.61 \\
1.12\end{array}$ & $\begin{array}{l}\text { - } \\
- \\
- \\
-\end{array}$ & & $\begin{array}{l}.465 \\
.205 \\
.197 \\
.161 \\
.141 \\
.134\end{array}$ & $\begin{array}{r}129 \\
48.9 \\
46.9 \\
37.8 \\
33.0 \\
31.4\end{array}$ \\
\hline$v_{3,10}$ & $\begin{array}{c}- \\
47.5 \\
6.77 \\
1.17 \\
.318 \\
.0316\end{array}$ & $\begin{array}{l}. \\
.86 \\
.87 \\
.91 \\
.90 \\
.90\end{array}$ & $\begin{array}{l}- \\
- \\
- \\
-\end{array}$ & $\begin{array}{l}- \\
- \\
- \\
- \\
- \\
.72\end{array}$ & $\begin{array}{c}- \\
- \\
-.45 \\
-.47 \\
-.69\end{array}$ & $\begin{array}{l}- \\
- \\
- \\
- \\
-\end{array}$ & $\begin{array}{r}- \\
- \\
.50 \\
1.10 \\
.93 \\
.90\end{array}$ & $\begin{array}{l}- \\
\overline{-} \\
- \\
- \\
-\end{array}$ & $\begin{array}{l}- \\
- \\
- \\
- \\
.47 \\
1.05\end{array}$ & $\begin{array}{l}- \\
- \\
- \\
- \\
-\end{array}$ & & $\begin{array}{l}.466 \\
.196 \\
.184 \\
.151 \\
.140 \\
.130\end{array}$ & $\begin{array}{l}129 \\
46.6 \\
43.6 \\
35.4 \\
32.8 \\
30.4\end{array}$ \\
\hline$v_{3,2}$ & $\begin{array}{l}18 . \\
.204 \\
.0650\end{array}$ & $\begin{array}{l}. \\
.90 \\
.92 \\
.95\end{array}$ & $\begin{array}{l}- \\
\text { - } \\
\text { - }\end{array}$ & $\begin{array}{l}- \\
- \\
-\end{array}$ & $\begin{array}{l}- \\
- \\
- \\
-.29\end{array}$ & $\begin{array}{l}- \\
- \\
-\end{array}$ & $\begin{array}{c}- \\
- \\
1.16 \\
1.55\end{array}$ & $\begin{array}{l}- \\
-\end{array}$ & $\begin{array}{l}- \\
-\end{array}$ & - & & $\begin{array}{l}.505 \\
.249 \\
.186 \\
.174\end{array}$ & $\begin{array}{r}144 \\
60.5 \\
44.1 \\
41.2\end{array}$ \\
\hline$v_{7,50}$ & $\begin{array}{c}- \\
49.0 \\
6.17 \\
1.53 \\
.337\end{array}$ & $\begin{array}{l}- \\
.86 \\
.87 \\
.91 \\
.89\end{array}$ & $\begin{array}{l}- \\
- \\
- \\
-\end{array}$ & $\begin{array}{l}- \\
- \\
-\end{array}$ & $\begin{array}{c}- \\
- \\
- \\
-.35 \\
-.38\end{array}$ & $\begin{array}{l}- \\
- \\
- \\
-\end{array}$ & $\begin{array}{r}- \\
- \\
.54 \\
1.01 \\
.81\end{array}$ & $\begin{array}{l}- \\
- \\
-\end{array}$ & $\begin{array}{l}- \\
- \\
- \\
.54\end{array}$ & $\begin{array}{l}- \\
\text { - } \\
\text { - }\end{array}$ & & $\begin{array}{l}.463 \\
.187 \\
.172 \\
.150 \\
.134\end{array}$ & $\begin{array}{l}128 \\
44.4 \\
40.6 \\
35.2 \\
31.4\end{array}$ \\
\hline$v_{7,20}$ & $\begin{array}{c}- \\
39.4 \\
3.99 \\
1.22 \\
.422 \\
.0486\end{array}$ & $\begin{array}{l}. \\
.86 \\
.88 \\
.91 \\
.90 \\
.90\end{array}$ & $\begin{array}{l}- \\
- \\
- \\
- \\
-\end{array}$ & $\begin{array}{l}- \\
- \\
- \\
- \\
.67\end{array}$ & $\begin{array}{c}- \\
- \\
- \\
-.30 \\
-.32 \\
-.53\end{array}$ & $\begin{array}{l}- \\
- \\
- \\
- \\
-\end{array}$ & $\begin{array}{l}- \\
. \\
.59 \\
.99 \\
.85 \\
.83\end{array}$ & $\begin{array}{l}- \\
\overline{-} \\
- \\
-\end{array}$ & $\begin{array}{l}- \\
- \\
- \\
- \\
.38 \\
.92\end{array}$ & $\begin{array}{l}\text { - } \\
\text { - } \\
\text { - }\end{array}$ & & $\begin{array}{l}.462 \\
.178 \\
.157 \\
.141 \\
.134 \\
.125\end{array}$ & $\begin{array}{l}128 \\
42.1 \\
36.0 \\
33.0 \\
31.4 \\
20.2\end{array}$ \\
\hline$v_{7,10}$ & $\begin{array}{c}- \\
31.8 \\
2.20 \\
.811 \\
.429 \\
.0412\end{array}$ & $\begin{array}{l}- \\
.88 \\
.89 \\
.91 \\
.91 \\
.91\end{array}$ & $\begin{array}{l}\bar{z} \\
\overline{-} \\
\overline{-} \\
\overline{-}\end{array}$ & $\begin{array}{l}- \\
- \\
- \\
- \\
- \\
.73\end{array}$ & $\begin{array}{c}- \\
- \\
- \\
-.25 \\
-.26 \\
-. .49\end{array}$ & $\begin{array}{l}- \\
- \\
- \\
-\end{array}$ & $\begin{array}{l}- \\
- \\
.69 \\
1.03 \\
.94 \\
.92\end{array}$ & $\begin{array}{l}- \\
- \\
- \\
- \\
-\end{array}$ & $\begin{array}{l}- \\
\\
\\
\\
\\
\\
\text { d } \\
- \\
.23 \\
.82 \\
.82\end{array}$ & $\begin{array}{l}- \\
- \\
- \\
-\end{array}$ & & $\begin{array}{l}.465 \\
.178 \\
.148 \\
.137 \\
.135 \\
.125\end{array}$ & $\begin{array}{l}129 \\
42.1 \\
34.7 \\
32.1 \\
31.6 \\
29.2\end{array}$ \\
\hline $\mathrm{v}_{7,2}$ & $\begin{array}{c}- \\
13.5 \\
.0543 \\
.0561\end{array}$ & $\begin{array}{l}- \\
.90 \\
.93 \\
.93\end{array}$ & $\begin{array}{l}- \\
- \\
-\end{array}$ & $\begin{array}{l}- \\
- \\
.36\end{array}$ & $\begin{array}{l}- \\
- \\
-\end{array}$ & $\begin{array}{l}- \\
-\end{array}$ & $\begin{array}{c}- \\
- \\
1.43 \\
1.39\end{array}$ & $\begin{array}{l}- \\
-\end{array}$ & $\begin{array}{l}- \\
- \\
-\end{array}$ & $\begin{array}{l}- \\
- \\
-\end{array}$ & & $\begin{array}{l}.516 \\
.265 \\
.167 \\
.160\end{array}$ & $\begin{array}{r}149 \\
64.8 \\
39.4 \\
37.6\end{array}$ \\
\hline $\mathrm{D}_{10}$ & $\begin{array}{l}- \\
3.04 \\
3.06(-4) \\
3.19(-4) \\
1.66(-5) \\
6.76(-5)\end{array}$ & $\begin{array}{l}- \\
1.00 \\
1.05 \\
1.05 \\
1.01 \\
.99\end{array}$ & $\begin{array}{l}- \\
- \\
- \\
-\end{array}$ & $\begin{array}{l}- \\
- \\
- \\
.49 \\
1.21 \\
.82\end{array}$ & $\begin{array}{l}- \\
- \\
- \\
-\end{array}$ & $\begin{array}{l}- \\
- \\
- \\
-\end{array}$ & $\begin{array}{l}- \\
- \\
2.38 \\
2.33 \\
1.75 \\
1.52\end{array}$ & $\begin{array}{l}- \\
- \\
- \\
- \\
- \\
.15\end{array}$ & $\begin{array}{l}- \\
- \\
- \\
- \\
1.17 \\
1.01\end{array}$ & $\begin{array}{l}\text { - } \\
- \\
- \\
-\end{array}$ & & $\begin{array}{l}.634 \\
.408 \\
.220 \\
.210 \\
.179 \\
.172\end{array}$ & $\begin{array}{l}108^{-} \\
52.8 \\
50.2 \\
42.4 \\
40.6\end{array}$ \\
\hline $\mathrm{D}_{50}$ & $\begin{array}{c}- \\
.0600 \\
1.70(-8) \\
2.04(-9) \\
2.10(-10)\end{array}$ & $\begin{array}{l}- \\
1.32 \\
1.41 \\
1.38 \\
1.35\end{array}$ & $\begin{array}{l}- \\
- \\
-\end{array}$ & $\begin{array}{l}- \\
- \\
- \\
- \\
1.23\end{array}$ & $\begin{array}{l}- \\
- \\
- \\
-\end{array}$ & $\begin{array}{l}- \\
- \\
- \\
-\end{array}$ & $\begin{array}{l}- \\
- \\
3.89 \\
3.54 \\
3.01\end{array}$ & $\begin{array}{l}- \\
- \\
- \\
-\end{array}$ & $\begin{array}{c}- \\
- \\
- \\
\\
\\
.82 \\
1.75\end{array}$ & $\begin{array}{l}- \\
\text { - } \\
\text { - }\end{array}$ & & $\begin{array}{l}.926 \\
.667 \\
.357 \\
.345 \\
.323\end{array}$ & $\begin{array}{r}- \\
- \\
91.8 \\
88.0 \\
81.4\end{array}$ \\
\hline
\end{tabular}


TABLE 9.-Summary of Western region regression relations: $\mathrm{Y}=\mathrm{a} \mathrm{A} \mathrm{A}_{1} \mathrm{Sb}_{2} \mathrm{St}_{4} \mathrm{E}_{4} \mathrm{~b}_{5} \mathrm{I}_{24,2} \mathrm{~b}_{6} \mathrm{P}_{7} \mathrm{Sn}_{8} \mathrm{~b}_{8} \mathrm{~F}_{9} \mathrm{Si}^{\mathrm{b}_{10}}$-Continued

\begin{tabular}{|c|c|c|c|c|c|c|c|c|c|c|c|c|c|}
\hline \multirow{2}{*}{$\begin{array}{l}\text { Flow } \\
\text { Index } \\
\mathrm{Y}\end{array}$} & \multirow{2}{*}{$\begin{array}{c}\text { Regression } \\
\text { Constant } \\
a^{*}\end{array}$} & \multicolumn{10}{|c|}{ Regression Coefficients for } & \multicolumn{2}{|c|}{$\begin{array}{c}\text { Standard } \\
\text { Error }\end{array}$} \\
\hline & & A & 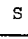 & st & $E$ & $I_{24,2}$ & $P$ & $\mathrm{Sn}$ & $F$ & $\mathrm{Si}$ & - & $\log s$ & 要 \\
\hline $\mathrm{D}_{90}$ & $\begin{array}{l}7.34(-3) \\
2.75(-5) \\
1.88(-5) \\
6.06(-3)\end{array}$ & $\begin{array}{l}- \\
1.35 \\
1.31 \\
1.25 \\
1.28\end{array}$ & $\begin{array}{l}- \\
\\
-\end{array}$ & $\begin{array}{l}- \\
- \\
-\end{array}$ & $\begin{array}{l}- \\
- \\
-\end{array}$ & $\begin{array}{c}- \\
4.37 \\
3.91 \\
5.27\end{array}$ & $\begin{array}{l}- \\
\vdots\end{array}$ & $\begin{array}{c}- \\
- \\
0.53 \\
.51\end{array}$ & $\begin{array}{c}- \\
\pm \\
- \\
-1.75\end{array}$ & $\begin{array}{l}- \\
- \\
-\end{array}$ & & $\begin{array}{r}1.054 \\
.826 \\
.650 \\
.585 \\
.558\end{array}$ & $\begin{array}{r}- \\
179 \\
167\end{array}$ \\
\hline$M_{7,2}$ & $\begin{array}{l}- \\
5.53(-5) \\
1.04(-7) \\
5.04(-8)\end{array}$ & $\begin{array}{l}- \\
- \\
1.41 \\
1.31\end{array}$ & - & $\begin{array}{l}- \\
-\end{array}$ & $\begin{array}{l}- \\
- \\
-\end{array}$ & $\begin{array}{l}- \\
8.10 \\
7.83 \\
6.96\end{array}$ & $\begin{array}{l}- \\
-\end{array}$ & $\begin{array}{c}- \\
- \\
1.00\end{array}$ & $\begin{array}{l}- \\
-\end{array}$ & $\begin{array}{l}- \\
\text { - }\end{array}$ & & $\begin{array}{r}1.467 \\
1.128 \\
.893 \\
.699\end{array}$ & $\begin{array}{l}- \\
- \\
-\end{array}$ \\
\hline $\mathrm{M}_{7,20}$ & $\begin{array}{l}- \\
3.99(-11) \\
2.47(-15) \\
8.61(-14) \\
1.84(-9)\end{array}$ & $\begin{array}{l}- \\
- \\
1.73 \\
1.63 \\
1.68\end{array}$ & $\overline{-}$ & $\begin{array}{l}- \\
= \\
-\end{array}$ & $\begin{array}{l}- \\
= \\
-\end{array}$ & $\begin{array}{c}- \\
- \\
- \\
4.59 \\
6.89\end{array}$ & $\begin{array}{l}- \\
4.47 \\
6.74 \\
4.31 \\
4.47\end{array}$ & $\begin{array}{l}- \\
- \\
-\end{array}$ & $\begin{array}{c}- \\
- \\
- \\
-3.17\end{array}$ & $\begin{array}{l}- \\
- \\
-\end{array}$ & & $\begin{array}{r}1.601 \\
1.533 \\
1.034 \\
.956 \\
.898\end{array}$ & $\begin{array}{l}- \\
\overline{-} \\
-\end{array}$ \\
\hline$Q_{A}$ & $\begin{array}{c}- \\
10.9 \\
7 \cdot 57(-4) \\
7 \cdot 79(-4)\end{array}$ & $\begin{array}{l}- \\
1.02 \\
1.06 \\
1.06\end{array}$ & $\begin{array}{l}- \\
- \\
-\end{array}$ & $\begin{array}{l}= \\
= \\
0.33\end{array}$ & : & $\begin{array}{l}- \\
- \\
-\end{array}$ & $\begin{array}{c}- \\
- \\
1.92 \\
1.89\end{array}$ & : & $\begin{array}{l}- \\
\vdots\end{array}$ & $\begin{array}{l}- \\
-\end{array}$ & & $\begin{array}{l}.589 \\
.314 \\
.147 \\
.141\end{array}$ & $\begin{array}{r}181 \\
78.8 \\
34.5 \\
33.0\end{array}$ \\
\hline$Q_{10}$ & $\begin{array}{l}- \\
.0205 \\
1.74(-10) \\
6.28(-10)\end{array}$ & $\begin{array}{l}- \\
5.24 \\
1.48 \\
1.44\end{array}$ & i & $\begin{array}{l}- \\
-\end{array}$ & $\begin{array}{l}- \\
-\end{array}$ & $\begin{array}{c}- \\
- \\
1.66\end{array}$ & $\begin{array}{c}- \\
- \\
4.80 \\
3.92\end{array}$ & $\begin{array}{l}- \\
-\end{array}$ & $\begin{array}{l}- \\
- \\
-\end{array}$ & $\begin{array}{l}- \\
-\end{array}$ & & $\begin{array}{r}1.077 \\
.848 \\
.489 \\
.470\end{array}$ & $\begin{array}{l}- \\
138^{-} \\
131\end{array}$ \\
\hline$Q_{11}$ & $\begin{array}{l}- \\
.279 \\
1.40(-5) \\
2.85(-5)\end{array}$ & $\begin{array}{l}- \\
1.06 \\
1.12 \\
1.09\end{array}$ & I- & $\begin{array}{l}- \\
- \\
-\end{array}$ & $\begin{array}{l}- \\
- \\
-\end{array}$ & $\begin{array}{c}- \\
- \\
1.04\end{array}$ & $\begin{array}{l}- \\
- \\
2.56 \\
2.01\end{array}$ & $\begin{array}{l}- \\
- \\
-\end{array}$ & $\begin{array}{l}- \\
- \\
-\end{array}$ & $\begin{array}{l}- \\
-\end{array}$ & & $\begin{array}{l}.695 \\
.463 \\
.280 \\
.267\end{array}$ & $\begin{array}{l}128^{-} \\
69.0 \\
65.3\end{array}$ \\
\hline$Q_{12}$ & $\begin{array}{l}- \\
1.02 \\
3.21(-3) \\
1.22(-4) \\
6.07(-6)\end{array}$ & $\begin{array}{l}8.15 \\
1.00 \\
1.07 \\
1.04\end{array}$ & I & $\begin{array}{l}- \\
- \\
-\end{array}$ & $\begin{array}{c}- \\
- \\
-0.83 \\
-.87\end{array}$ & $\begin{array}{l}\overline{-} \\
- \\
-\end{array}$ & $\begin{array}{l}- \\
- \\
1.49 \\
2.59 \\
2.20\end{array}$ & $\begin{array}{l}- \\
- \\
-\end{array}$ & $\begin{array}{c}- \\
- \\
- \\
1.08\end{array}$ & $\begin{array}{l}- \\
- \\
-\end{array}$ & & $\begin{array}{l}.606 \\
.382 \\
.318 \\
.249 \\
.207\end{array}$ & $\begin{array}{l}- \\
99.6 \\
79.9 \\
60.4 \\
49.5\end{array}$ \\
\hline$Q_{1}$ & $\begin{array}{c}- \\
.884 \\
.0183 \\
1.87(-4) \\
8.36(-6)\end{array}$ & $\begin{array}{l}- \\
1.03 \\
1.05 \\
1.16 \\
1.12\end{array}$ & $\begin{array}{l}\text { - } \\
\text { - }\end{array}$ & $\begin{array}{l}- \\
- \\
-\end{array}$ & $\begin{array}{c}- \\
- \\
-1.16 \\
-1.22\end{array}$ & $\begin{array}{l}- \\
- \\
-\end{array}$ & $\begin{array}{c}- \\
- \\
1.00 \\
2.55 \\
2.14\end{array}$ & $\begin{array}{l}- \\
\overline{-} \\
-\end{array}$ & $\begin{array}{c}- \\
- \\
- \\
1.11\end{array}$ & $\begin{array}{l}- \\
- \\
-\end{array}$ & & $\begin{array}{l}.643 \\
.403 \\
.380 \\
.256 \\
.213\end{array}$ & $\begin{array}{l}110^{-} \\
99.2 \\
62.4 \\
51.0\end{array}$ \\
\hline$Q_{2}$ & $\begin{array}{l}- \\
1.62 \\
2.84 \\
7.57(-4) \\
2.00(-5)\end{array}$ & $\begin{array}{l}- \\
1.00 \\
1.03 \\
1.12 \\
1.08\end{array}$ & $\begin{array}{l}- \\
-\end{array}$ & $\begin{array}{l}- \\
- \\
- \\
-\end{array}$ & $\begin{array}{c}- \\
-.44 \\
-.1 .15 \\
-1.20\end{array}$ & $\begin{array}{l}- \\
-\end{array}$ & $\begin{array}{c}- \\
= \\
2.34 \\
1.86\end{array}$ & $\begin{array}{l}- \\
- \\
-\end{array}$ & $\begin{array}{c}- \\
- \\
- \\
1.30\end{array}$ & $\begin{array}{l}- \\
- \\
-\end{array}$ & & $\begin{array}{l}.618 \\
.380 \\
.359 \\
.242 \\
.174\end{array}$ & $\begin{array}{c}- \\
99.3 \\
92.5 \\
58.6 \\
41.1\end{array}$ \\
\hline$Q_{3}$ & $\begin{array}{l}- \\
1.96 \\
.0127 \\
1.25(-3) \\
9.00(-5)\end{array}$ & $\begin{array}{l}- \\
.98 \\
1.00 \\
1.06 \\
1.03\end{array}$ & $\begin{array}{l}- \\
- \\
-\end{array}$ & $\begin{array}{l}\overline{-} \\
\overline{-} \\
-\end{array}$ & $\begin{array}{c}- \\
- \\
-.59 \\
-.64\end{array}$ & $\begin{array}{l}- \\
- \\
-\end{array}$ & $\begin{array}{l}- \\
1.30 \\
2.09 \\
1.7^{4}\end{array}$ & $\begin{array}{l}- \\
- \\
-\end{array}$ & $\begin{array}{l}- \\
- \\
- \\
.94\end{array}$ & $\begin{array}{l}- \\
- \\
-\end{array}$ & & $\begin{array}{l}.564 \\
.299 \\
.234 \\
.188 \\
.143\end{array}$ & $\begin{array}{l}170 \\
74.4 \\
56.7 \\
44.5 \\
33.6\end{array}$ \\
\hline$\theta_{4}$ & $\begin{array}{l}- \\
2.92 \\
4.26(-4) \\
1.35(-3) \\
3.49(-4)\end{array}$ & $\begin{array}{r}- \\
.97 \\
1.02 \\
.99 \\
.96\end{array}$ & $\begin{array}{l}- \\
- \\
-\end{array}$ & 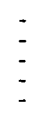 & $\begin{array}{l}5 \\
\vdots\end{array}$ & $\begin{array}{l}\overline{-} \\
\overline{-} \\
\overline{-}\end{array}$ & $\begin{array}{l}- \\
- \\
2.28 \\
1.90 \\
1.55\end{array}$ & $\begin{array}{l}- \\
- \\
.17 \\
.21\end{array}$ & $\begin{array}{l}- \\
- \\
- \\
.62\end{array}$ & $\begin{array}{l}- \\
- \\
-\end{array}$ & & $\begin{array}{l}.601 \\
.368 \\
.163 \\
.142 \\
.119\end{array}$ & $\begin{array}{c}- \\
95.5 \\
38.1 \\
33.3 \\
27.8\end{array}$ \\
\hline$Q_{5}$ & $\begin{array}{l}- \\
5.58 \\
.0637 \\
6.11(-5) \\
2.37(-5) \\
9.34(-6)\end{array}$ & $\begin{array}{l}- \\
- \\
1.01 \\
1.09 \\
1.08 \\
1.07\end{array}$ & $\begin{array}{l}- \\
- \\
- \\
-\end{array}$ & $\begin{array}{l}- \\
= \\
= \\
-\end{array}$ & $\begin{array}{l}- \\
2.46 \\
2.29 \\
1.71 \\
1.69 \\
1.15\end{array}$ & $\begin{array}{l}- \\
\vdots \\
- \\
-\end{array}$ & $\begin{array}{c}- \\
- \\
- \\
1.98 \\
1.85 \\
1.71\end{array}$ & $\begin{array}{l}5 \\
- \\
- \\
5 \\
.32\end{array}$ & $\begin{array}{l}- \\
- \\
- \\
\\
.34 \\
.70\end{array}$ & $\begin{array}{l}- \\
\vdots \\
-\end{array}$ & & $\begin{array}{l}.947 \\
.575 \\
.289 \\
.181 \\
.178 \\
.164\end{array}$ & $\begin{array}{l}170 \\
71.5 \\
42.8 \\
40.9 \\
38.6\end{array}$ \\
\hline
\end{tabular}


RESULTS

TABLE 9.-Summary of Western region regression relations:

$\mathrm{Y}=\mathrm{a} \mathrm{A}_{1} \mathrm{~b}_{2} \mathrm{~b}_{2} \mathrm{St}_{4}{ }_{4} \mathrm{E}_{5} \mathrm{I}_{24,2} \mathrm{~b}_{6} \mathrm{P}_{7} \mathrm{Sn}_{8} \mathrm{~b}_{8} \mathrm{~F}_{8} \mathrm{Si}^{\mathrm{b}_{10}}$-Continued

\begin{tabular}{|c|c|c|c|c|c|c|c|c|c|c|c|c|c|}
\hline \multirow{2}{*}{$\begin{array}{l}\text { Flow } \\
\text { Index } \\
\quad \mathrm{Y}\end{array}$} & \multirow{2}{*}{$\begin{array}{c}\text { Regression } \\
\text { Constant } \\
a^{*}\end{array}$} & \multicolumn{10}{|c|}{ Regression Coefficients for } & \multicolumn{2}{|c|}{$\begin{array}{c}\text { Standard } \\
\text { Error }\end{array}$} \\
\hline & & A & $\mathrm{s}$ & St & $\mathrm{E}$ & $I_{24,2}$ & $P$ & $\mathrm{Sn}$ & $\mathbf{F}$ & $\mathrm{Si}$ & - & logs & $\%$ \\
\hline$Q_{6}$ & $\begin{array}{l}- \\
8.57(-6) \\
6.69(-3) \\
6.42(-6) \\
4.26(-6) \\
7.29(-6) \\
4.94(-7) \\
1.50(-7)\end{array}$ & $\begin{array}{l}- \\
- \\
1.16 \\
1.24 \\
1.25 \\
1.23 \\
1.23 \\
1.21\end{array}$ & $\begin{array}{l}- \\
- \\
- \\
-\end{array}$ & $\begin{array}{c}- \\
- \\
- \\
\text { d } 0.42 \\
.83 \\
1.40 \\
1.54\end{array}$ & $\begin{array}{l}- \\
3.07 \\
2.87 \\
2.29 \\
2.18 \\
2.12 \\
1.92 \\
1.36\end{array}$ & $\begin{array}{c}- \\
- \\
- \\
- \\
0.95 \\
0.88 \\
.95\end{array}$ & $\begin{array}{c}- \\
- \\
- \\
1.98 \\
2.09 \\
1.62 \\
1.54 \\
1.37\end{array}$ & $\begin{array}{l}- \\
- \\
- \\
- \\
- \\
- \\
2.15\end{array}$ & $\begin{array}{c}- \\
- \\
- \\
- \\
- \\
\alpha \\
0.74 \\
1.17\end{array}$ & $\begin{array}{l}- \\
: \\
- \\
-\end{array}$ & & $\begin{array}{l}1.142 \\
.653 \\
.321 \\
.230 \\
.226 \\
.217 \\
.212 \\
.202\end{array}$ & $\begin{array}{l}- \\
80.7 \\
55.3 \\
54.4 \\
52.0 \\
50.7 \\
48.1\end{array}$ \\
\hline $\mathrm{Q}_{7}$ & $\begin{array}{c}- \\
.462 \\
1.35(-3) \\
1.86(-4) \\
3.16(-5) \\
4.84(-7)\end{array}$ & $\begin{array}{l}- \\
- \\
1.32 \\
1.31 \\
1.34 \\
1.40\end{array}$ & $\begin{array}{l}- \\
- \\
-\end{array}$ & $\begin{array}{c}- \\
- \\
- \\
2.10 \\
1.80\end{array}$ & $\begin{array}{l}- \\
2.82 \\
2.60 \\
2.38 \\
1.80 \\
1.54\end{array}$ & $\begin{array}{c}- \\
- \\
- \\
1.76 \\
3.23 \\
2.08\end{array}$ & $\begin{array}{l}- \\
- \\
- \\
- \\
1.56\end{array}$ & $\begin{array}{l}\overline{-} \\
\overline{-} \\
\overline{-}\end{array}$ & $\begin{array}{l}- \\
- \\
-\end{array}$ & $\begin{array}{l}5 \\
:\end{array}$ & & $\begin{array}{l}1.160 \\
.778 \\
.431 \\
.386 \\
.319 \\
.289\end{array}$ & $\begin{array}{c}- \\
116^{-} \\
100 \\
80.2 \\
71.5\end{array}$ \\
\hline$Q_{8}$ & $\begin{array}{l}- \\
8.37(-3) \\
6.42(-4) \\
1.80(-5) \\
.0298 \\
3.7^{4}(-5)\end{array}$ & $\begin{array}{l}- \\
1.52 \\
1.38 \\
1.37 \\
1.40 \\
1.49\end{array}$ & $\begin{array}{l}- \\
- \\
-\end{array}$ & $\begin{array}{l}- \\
5 \\
-\end{array}$ & $\begin{array}{c}- \\
2.11 \\
1.72 \\
1.88 \\
1.39\end{array}$ & $\begin{array}{c}- \\
- \\
3.18 \\
4.77 \\
3.34\end{array}$ & $\begin{array}{l}- \\
- \\
- \\
- \\
- \\
2.20\end{array}$ & $\begin{array}{l}- \\
\overline{-} \\
- \\
-\end{array}$ & $\begin{array}{c}- \\
- \\
- \\
-2.26 \\
-2.12\end{array}$ & $\begin{array}{l}- \\
- \\
-\end{array}$ & & $\begin{array}{l}1.180 \\
.923 \\
.660 \\
.559 \\
.505 \\
.467\end{array}$ & $\begin{array}{l}= \\
165^{-} \\
144 \\
130\end{array}$ \\
\hline$Q_{9}$ & $\begin{array}{l}- \\
8.20(-3) \\
4.26(-10) \\
1.96(-9) \\
1.46(-7) \\
7.56(-6)\end{array}$ & $\begin{array}{l}. \\
1.45 \\
1.54 \\
1.50 \\
1.52 \\
1.46\end{array}$ & $\begin{array}{l}5 \\
5 \\
5\end{array}$ & $\begin{array}{l}- \\
- \\
-\end{array}$ & $\begin{array}{l}- \\
- \\
- \\
- \\
.71\end{array}$ & $\begin{array}{c}- \\
: \\
1.97 \\
2.97 \\
3.44\end{array}$ & $\begin{array}{l}- \\
- \\
4.33 \\
3.29 \\
3.36 \\
2.30\end{array}$ & $\begin{array}{l}- \\
- \\
- \\
-\end{array}$ & $\begin{array}{c}- \\
- \\
- \\
d-1.37 \\
-1.68\end{array}$ & $\begin{array}{l}- \\
- \\
-\end{array}$ & & $\begin{array}{l}1.102 \\
.851 \\
.579 \\
.557 \\
.542 \\
.521\end{array}$ & $\begin{array}{l}- \\
175 \\
165 \\
160 \\
152\end{array}$ \\
\hline $\mathrm{SD}_{\mathrm{A}}$ & $\begin{array}{l}- \\
.760 \\
7.05(-3)\end{array}$ & $\begin{array}{r}. \\
.98 \\
1.00\end{array}$ & - & - & - & $\overline{-}$ & $\begin{array}{l}- \\
-21\end{array}$ & $\overline{-}$ & - & - & & $\begin{array}{l}.522 \\
.206 \\
.109\end{array}$ & $\begin{array}{l}152 \\
49.2 \\
25.4\end{array}$ \\
\hline $\mathrm{SD}_{10}$ & $\begin{array}{l}- \\
.0478 \\
1.66(-9)\end{array}$ & $\begin{array}{l}- \\
1.21 \\
1.31\end{array}$ & - & - & - & $\overline{-}$ & $\begin{array}{c}- \\
4.44\end{array}$ & - & - & - & & $\begin{array}{l}.980 \\
.787 \\
.457\end{array}$ & 125 \\
\hline $\mathrm{SD}_{11}$ & $\begin{array}{l}.909 \\
1.07(-3)\end{array}$ & $\begin{array}{l}- \\
.88 \\
.91\end{array}$ & - & - & - & $\overline{-}$ & $\begin{array}{c}- \\
1.74\end{array}$ & - & - & - & & $\begin{array}{l}.566 \\
.371 \\
.275\end{array}$ & $\begin{array}{c}171 \\
96.4 \\
67.6\end{array}$ \\
\hline $\mathrm{sD}_{12}$ & $\begin{array}{l}2 . \\
.028 \\
8.23(-4) \\
2.94(-5)\end{array}$ & $\begin{array}{l}-. \\
.83 \\
.86 \\
.94 \\
.91\end{array}$ & $\begin{array}{l}- \\
- \\
-\end{array}$ & - & $\begin{array}{c}- \\
- \\
- \\
-.90 \\
-.96\end{array}$ & $\begin{array}{l}- \\
- \\
-\end{array}$ & $\begin{array}{l}: \\
- \\
1.15 \\
2.35 \\
1.91\end{array}$ & $\begin{array}{l}- \\
- \\
-\end{array}$ & $\begin{array}{l} \pm \\
: \\
1.20\end{array}$ & $\begin{array}{l}- \\
- \\
-\end{array}$ & & $\begin{array}{l}.554 \\
.377 \\
.341 \\
.264 \\
.216\end{array}$ & $\begin{array}{l}165 \\
97.9 \\
86.7 \\
64.6 \\
51.8\end{array}$ \\
\hline $\mathrm{SD}_{1}$ & $\begin{array}{l}- \\
.985 \\
2.09 \\
4.15(-4) \\
7.24(-6)\end{array}$ & $\begin{array}{l}- \\
.99 \\
1.03 \\
1.13 \\
1.08\end{array}$ & $\begin{array}{l}- \\
- \\
-\end{array}$ & $\begin{array}{l}- \\
- \\
-\end{array}$ & $\begin{array}{c}- \\
- \\
-.62 \\
-1.33 \\
-1.41\end{array}$ & $\begin{array}{l}- \\
- \\
-\end{array}$ & $\begin{array}{c}- \\
- \\
2.43 \\
1.89\end{array}$ & $\begin{array}{l}- \\
- \\
-\end{array}$ & $\begin{array}{c}- \\
- \\
- \\
1.45\end{array}$ & $\begin{array}{l}- \\
- \\
-\end{array}$ & & $\begin{array}{l}.643 \\
.428 \\
.341 \\
.264 \\
.216\end{array}$ & $\begin{array}{l}116^{-} \\
102 \\
66.9 \\
46.9\end{array}$ \\
\hline $\mathrm{SD}_{2}$ & $\begin{array}{l}- \\
1.63 \\
3.87 \\
8.07(-4) \\
1.73(-5)\end{array}$ & $\begin{array}{l}- \\
.94 \\
.99 \\
.96 \\
1.03\end{array}$ & $\begin{array}{l}- \\
- \\
-\end{array}$ & $\begin{array}{l}- \\
- \\
-\end{array}$ & $\begin{array}{c}- \\
- \\
-.71 \\
-1.05 \\
-1.44\end{array}$ & $\begin{array}{l}- \\
- \\
-\end{array}$ & $\begin{array}{l}- \\
- \\
- \\
- \\
1.56\end{array}$ & $\begin{array}{l}- \\
- \\
-\end{array}$ & $\begin{array}{c}- \\
- \\
- \\
2.08 \\
1.67\end{array}$ & $\begin{array}{l}- \\
- \\
-\end{array}$ & & $\begin{array}{l}.626 \\
.426 \\
.369 \\
.240 \\
.168\end{array}$ & $\begin{array}{l}- \\
115 \\
95.7 \\
58.0 \\
39.6\end{array}$ \\
\hline $\mathrm{SD}_{3}$ & $\begin{array}{l}- \\
1.69 \\
.0120 \\
3.44(-3) \\
1.60(-4)\end{array}$ & $\begin{array}{l}. \\
.91 \\
.88 \\
.91 \\
.97\end{array}$ & $\begin{array}{l}- \\
- \\
-\end{array}$ & $\begin{array}{l}- \\
- \\
-\end{array}$ & $\begin{array}{c}- \\
- \\
-.63 \\
-.95\end{array}$ & $\begin{array}{l}- \\
- \\
-\end{array}$ & $\begin{array}{c}- \\
- \\
- \\
1.25\end{array}$ & $\begin{array}{l}- \\
- \\
-\end{array}$ & $\begin{array}{c}- \\
- \\
1.16 \\
1.63 \\
1.30\end{array}$ & $\begin{array}{l}- \\
- \\
-\end{array}$ & & $\begin{array}{l}.546 \\
.315 \\
.272 \\
.201 \\
.147\end{array}$ & $\begin{array}{l}162 \\
79.1 \\
66.6 \\
47.7 \\
34.5\end{array}$ \\
\hline
\end{tabular}




\section{TABLE 9.-Summary of Western region regression relations:}

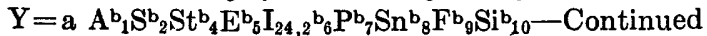

\begin{tabular}{|c|c|c|c|c|c|c|c|c|c|c|c|c|c|}
\hline \multirow{2}{*}{$\begin{array}{l}\text { Flow } \\
\text { Index } \\
Y\end{array}$} & \multirow{2}{*}{$\begin{array}{c}\text { Regression } \\
\text { Constant } \\
\mathrm{a}^{*}\end{array}$} & \multicolumn{10}{|c|}{ Regression Coefficients for } & \multicolumn{2}{|c|}{$\begin{array}{l}\text { Standard } \\
\text { Error }\end{array}$} \\
\hline & & A & S & st & $E$ & $I_{24,2}$ & $P$ & Sn & $\mathrm{F}$ & $\mathrm{Si}$ & - & $\operatorname{logs}$ & $\%$ \\
\hline$S D_{4}$ & $\begin{array}{l}- \\
2.88 \\
.0456 \\
.0150 \\
3.43(-3)\end{array}$ & $\begin{array}{l}- \\
0.85 \\
.87 \\
.89 \\
.88\end{array}$ & $\begin{array}{l}- \\
\\
-\end{array}$ & $\begin{array}{l}- \\
- \\
- \\
-\end{array}$ & $\begin{array}{c}- \\
- \\
- \\
-0.28 \\
-.31\end{array}$ & $\begin{array}{l}- \\
- \\
-\end{array}$ & $\begin{array}{l}- \\
1.07 \\
1.45 \\
1.25\end{array}$ & $\begin{array}{l}- \\
- \\
-\end{array}$ & $\begin{array}{c}- \\
- \\
- \\
0.53\end{array}$ & $\begin{array}{l}- \\
- \\
- \\
-\end{array}$ & & $\begin{array}{l}0.466 \\
.213 \\
.148 \\
.132 \\
.114\end{array}$ & $\begin{array}{c}148 \\
50.5 \\
34.6 \\
30.9 \\
26.6\end{array}$ \\
\hline $\mathrm{SD}_{5}$ & $\begin{array}{c}- \\
13.8 \\
.201 \\
6.68(-5) \\
6.78(-6) \\
3.27(-5)\end{array}$ & $\begin{array}{l}- \\
. \\
.94 \\
.90 \\
.95 \\
.95\end{array}$ & $\begin{array}{l}- \\
\\
- \\
-\end{array}$ & $\begin{array}{l}- \\
- \\
- \\
- \\
-\end{array}$ & $\begin{array}{l}- \\
- \\
- \\
- \\
.67\end{array}$ & $\begin{array}{l}5 \\
- \\
-\end{array}$ & $\begin{array}{c}- \\
- \\
- \\
1.21 \\
1.15\end{array}$ & $\begin{array}{l}- \\
0.95 \\
.87 \\
.83 \\
.67 \\
.36\end{array}$ & $\begin{array}{c}- \\
- \\
- \\
1.89 \\
1.40 \\
1.03\end{array}$ & $\begin{array}{l}- \\
\vdots \\
-\end{array}$ & & $\begin{array}{l}.780 \\
.571 \\
.334 \\
.194 \\
.145 \\
.122\end{array}$ & $\begin{array}{r}164 \\
84.8 \\
46.0 \\
34.0 \\
28.5\end{array}$ \\
\hline $\mathrm{SD}_{6}$ & $\begin{array}{c}- \\
1.39 \\
.0135 \\
2.76(-4) \\
2.98(-4) \\
1.47(-4) \\
7.93(-6)\end{array}$ & $\begin{array}{l}- \\
- \\
1.05 \\
1.09 \\
1.09 \\
1.08 \\
1.08\end{array}$ & $\begin{array}{l}- \\
- \\
- \\
- \\
-\end{array}$ & $\begin{array}{l}- \\
- \\
- \\
- \\
- \\
0.87\end{array}$ & $\begin{array}{l}- \\
2.68 \\
2.50 \\
2.18 \\
1.66 \\
1.54 \\
1.21\end{array}$ & $\begin{array}{l}- \\
- \\
- \\
-\end{array}$ & $\begin{array}{l}= \\
- \\
1.11 \\
1.10 \\
1.00 \\
.95\end{array}$ & $\begin{array}{l}- \\
- \\
- \\
- \\
.32 \\
.39 \\
.42\end{array}$ & $\begin{array}{c}- \\
- \\
- \\
- \\
.26 \\
1.01\end{array}$ & $\begin{array}{l}- \\
- \\
- \\
- \\
-\end{array}$ & & $\begin{array}{l}.997 \\
.568 \\
.237 \\
.203 \\
.186 \\
.187 \\
.176\end{array}$ & $\begin{array}{c}- \\
172 \\
57.3 \\
48.4 \\
44.2 \\
44.2 \\
41.6\end{array}$ \\
\hline $\mathrm{SD}_{7}$ & $\begin{array}{l}- \\
.422 \\
1.46(-3) \\
1.38(-3) \\
1.25(-5)\end{array}$ & $\begin{array}{c}- \\
- \\
1.28 \\
1.29 \\
1.35\end{array}$ & 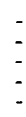 & $\begin{array}{l}- \\
- \\
.97 \\
1.23\end{array}$ & $\begin{array}{l}- \\
2.70 \\
2.48 \\
2.29 \\
1.85\end{array}$ & $\begin{array}{l}- \\
- \\
-\end{array}$ & $\begin{array}{l}- \\
- \\
- \\
1 . \\
1 .\end{array}$ & $\begin{array}{l}- \\
- \\
-\end{array}$ & $\begin{array}{l}- \\
- \\
-\end{array}$ & $\begin{array}{l}- \\
- \\
-\end{array}$ & & $\begin{array}{r}1.081 \\
.702 \\
.309 \\
.285 \\
.245\end{array}$ & $\begin{array}{r}- \\
- \\
77.4 \\
70.4 \\
59.4\end{array}$ \\
\hline $\mathrm{SD}_{8}$ & $\begin{array}{l}- \\
8.06(-3) \\
7.48(-4) \\
6.16(-7) \\
2.42(-5)\end{array}$ & $\begin{array}{l}- \\
1.45 \\
1.32 \\
1.40 \\
1.44\end{array}$ & $\begin{array}{l}- \\
\\
-\end{array}$ & $\begin{array}{l}- \\
\overline{-} \\
-\end{array}$ & $\begin{array}{c}- \\
- \\
1.96 \\
1.36 \\
1.43\end{array}$ & $\begin{array}{l}- \\
- \\
-\end{array}$ & $\begin{array}{c}- \\
= \\
2.02 \\
2.50\end{array}$ & $\begin{array}{l}- \\
- \\
-\end{array}$ & $\begin{array}{c}- \\
- \\
- \\
-1.32\end{array}$ & $\begin{array}{l}- \\
- \\
-\end{array}$ & & $\begin{array}{r}1.043 \\
.770 \\
.481 \\
.427 \\
.396\end{array}$ & $\begin{array}{l}- \\
135 \\
115 \\
104\end{array}$ \\
\hline $\mathrm{SD}_{9}$ & $\begin{array}{l}- \\
.0152 \\
5.03(-8)\end{array}$ & $\begin{array}{c}- \\
1.24 \\
1.31\end{array}$ & $\overline{-}$ & $\begin{array}{l}- \\
-\end{array}$ & - & : & $\begin{array}{l}- \\
- \\
3.26\end{array}$ & - & - & $\begin{array}{l}- \\
\end{array}$ & & $\begin{array}{l}.913 \\
.688 \\
.506\end{array}$ & $144^{-}$ \\
\hline
\end{tabular}

* Number in ( $)$ is power of 10 by which value must be multipliea. 
In general, these tables show several relations for each flow characteristic. The top line for a characteristic shows its standard deviation, a measure of the error in using the mean of the sample data as an estimate of that characteristic at any site. The second line indicates the most accurate relation when using one independent variable, and succeeding lines indicate more complex relations of increasingly superior accuracy. The last line for each streamflow characteristic shows the most accurate relation in which all basin characteristics are effective with at least 95-percent confidence. For the majority of relations in tables 6-9, the regression coefficients are statistically significant at the 95-percent confidence level. A few relations are shown for which one regression coefficient is nonsignificant at the 95-percent level. These relations are included for consistency with alternate relations for that flow characteristic as was previously discussed.

Tables 6-9 show regression relations for all investigated flow characteristics, except the monthly and annual skew coefficients and 1-yearlag serial correlation coefficients.

For the skew coefficients, regression on basin characteristics generally did not lead to standard errors that were significantly less than the standard deviations of the sample values. In other words, there was little or no improvement by use of the basin characteristics. Plotting of skew coefficients at station locations on study region maps shows that for some months there is an areal pattern to the coefficients, whereas for other months no areal pattern exists. Skew coefficients for ungaged sites can best be estimated by averaging several station values over an area that may be delineated from a regional map upon which the skew coefficients are shown.

Attempts to relate annual first-order serial correlation coefficients for annual and monthly means to hydrologic basin characteristics met little success. In general, these coefficients were not significantly different from zero in any of the four study regions; therefore, little likelihood exists for definition of meaningful relations.

\section{DISCUSSION OF RESULTS}

\section{VARIABLES EFFECTIVE IN EXPLAINING STREAMFLOW VARIATION}

This study defined empirical relations between natural streamflow characteristics and climatic and topographic characteristics of the drainage basins. To some degree, hydrologic knowledge was used in the initial selection of basin characteristics for these equations. However, the basis for retention of those shown in tables 6-9 was primarily statistical. The interrelations between the basin indices along with the inability of the indices to describe completely a drainage basin makes tenuous any assertions about the physical effects of the basin charac- 
teristics on runoff. As an example, snow was selected as an index of storage, but in the Potomac River basin snow is highly related inversely to precipitation intensity. Perhaps the basin-to-basin variation of snow is more accurately defined than the variability of precipitation intensity, which was evaluated from highly generalized maps, so that the effect of snow in the defined relations may be actually a measure of precipitation intensity rather than of storage. Other pairs of basin indices could be similarly compared to accentuate the futility of determining cause and effect on the basis of the regression relations.

Despite the inability of the relations to describe the fundamental causes of streamflow variation, the basin indices significant in the relations are numerical measures that are related to the flow variations. These significant indices may be used to select basins having wide differences in a flow characteristics. A stream-gaging network could therefore be designed to sample a wide variation of selected flow characteristics on the basis of basin characteristics. Table 10 summarizes for each study region the basin characteristics found effective for explaining basin-to-basin flow variations. In the table, the high flow classification includes flood peaks and flood volumes; the average flow classification includes annual mean, monthly means, 10-percent duration, and 50-percent duration; low flow includes annual minimum 7-day flows and 90 -percent durations; and the flow variability classification includes the standard deviations for annual and monthly means.

\section{ACGURACY OF DEFINED RELATIONS}

The standard error of estimate measures the accuracy of the regression relations. It shows the streamflow variation unexplained by the basin characteristics used, and therefore indicates the success of each relation.

Accuracy of most defined relations is shown graphically in figures 13-16. These figures indicate that in each study region the defined relations are most accurate for flows nearest the mean and become less accurate for extreme flows, being least accurate for extreme low flows. Accuracy of the peak-flow relations compares favorably with the accuracy of peak-flow relations defined by Benson $(1962,1964)$ for New England and the Southwestern United States. Annual mean-flow relations were found to be more accurate for the humid Eastern and Southern regions than for the more arid Central and Western regions. Monthly mean-flow relations were more accurate in each study region for months of high flows than for months of low flows, and again, were more accurate for the Eastern and Southern regions than for the Central and Western regions. Low-flow relations are unreliable in all study regions; they can provide only rough estimates of low-flow characteristics at ungaged sites. 
TABLE 10.-Basin characteristics found to be significantly related to streamflow

[The numbers under each hydrologic characteristic denote the number of relations in which that character istic was found significant within at least a 95 percent confidence limit]

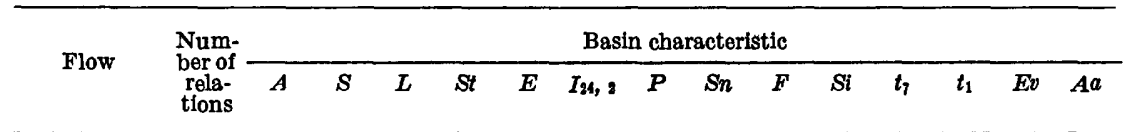

Eastern region

\begin{tabular}{|c|c|c|c|c|c|c|c|c|c|c|c|}
\hline $\begin{array}{l}\text { High. } \\
\text { Average......... } \\
\text { Low } \\
\text { Variable...... } \\
\text { Total. . }\end{array}$ & $\begin{array}{r}14 \\
15 \\
3 \\
13 \\
45\end{array}$ & $\begin{array}{r}14 \\
15 \\
3 \\
13 \\
45\end{array}$ & $\begin{array}{r}6 \\
3 \\
1 \\
0 \\
10\end{array}$ & $\begin{array}{l}\mathbf{5} \\
0 \\
0 \\
\mathbf{2} \\
\mathbf{7}\end{array}$ & $\begin{array}{l}3 \\
4 \\
0 \\
1 \\
8\end{array}$ & $\begin{array}{l}0 \\
0 \\
0 \\
1 \\
1\end{array}$ & $\begin{array}{c}3 \\
0 \\
0 \\
0 \\
3\end{array}$ & $\begin{array}{r}0 \\
14 \\
2 \\
7 \\
23\end{array}$ & $\begin{array}{r}2 \\
13 \\
1 \\
0 \\
16\end{array}$ & $\begin{array}{r}11 \\
2 \\
2 \\
8 \\
23\end{array}$ & 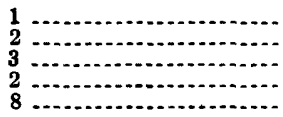 \\
\hline
\end{tabular}

Central region

\begin{tabular}{|c|c|c|c|c|c|c|c|c|c|c|c|c|c|}
\hline $\begin{array}{l}\text { High } \\
\text { Average....... } \\
\text { Low. } \\
\text { Variable } \\
\text { Total .... }\end{array}$ & $\begin{array}{r}14 \\
15 \\
4 \\
14 \\
47\end{array}$ & $\begin{array}{r}14 \\
15 \\
4 \\
14 \\
47\end{array}$ & $\begin{array}{l}0 \\
0 \\
0 \\
0 \\
0\end{array}$ & $\begin{array}{lll}5 & \ldots & \\
0 & \ldots & \ldots \\
0 & \ldots \ldots \\
2 & \ldots & \ldots \\
7 & \ldots\end{array}$ & $\begin{array}{l}0 \\
0 \\
0 \\
0 \\
0\end{array}$ & $\begin{array}{l}0 \\
0 \\
0 \\
0 \\
0\end{array}$ & $\begin{array}{r}13 \\
15 \\
3 \\
13 \\
44\end{array}$ & $\begin{array}{r}11 \\
3 \\
1 \\
6 \\
21\end{array}$ & $\begin{array}{l}0 \\
0 \\
0 \\
0 \\
0\end{array}$ & $\begin{array}{r}1 \\
7 \\
2 \\
0 \\
10\end{array}$ & 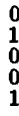 & & $\begin{array}{l}0 \\
0 \\
0 \\
1 \\
1\end{array}$ \\
\hline
\end{tabular}

\begin{tabular}{|c|c|c|c|c|c|c|c|c|c|c|}
\hline \multicolumn{11}{|c|}{ Southern region } \\
\hline $\begin{array}{l}\text { High......... } \\
\text { Average....... } \\
\text { Low ariable } \\
\text { Total.... }\end{array}$ & $\begin{array}{r}14 \\
15 \\
3 \\
13 \\
45\end{array}$ & $\begin{array}{r}14 \\
15 \\
3 \\
13 \\
45\end{array}$ & $\begin{array}{r}5 \\
5 \\
3 \\
2 \\
15\end{array}$ & $\begin{array}{l}1 \\
0 \\
0 \\
3 \\
4\end{array}$ & $\begin{array}{l}4 \\
0 \\
0 \\
1 \\
5\end{array}$ & $\begin{array}{l}0 \\
0 \\
0 \\
1 \\
1\end{array}$ & $\begin{array}{r}11 \\
0 \\
0 \\
5 \\
16\end{array}$ & 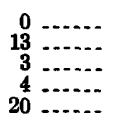 & $\begin{array}{l}\mathbf{1} \\
\mathbf{3} \\
\mathbf{0} \\
\mathbf{1} \\
\mathbf{5}\end{array}$ & $\begin{array}{l}0 \\
4 \\
4\end{array}$ \\
\hline
\end{tabular}

Western region

\begin{tabular}{|c|c|c|c|c|c|c|c|c|c|c|}
\hline $\begin{array}{l}\text { High } \\
\text { Average } \\
\text { Low } \\
\text { Variable......... } \\
\text { Total... }\end{array}$ & $\begin{array}{r}14 \\
15 \\
3 \\
13 \\
45\end{array}$ & $\begin{array}{r}14 \\
15 \\
3 \\
13 \\
45\end{array}$ & $\left.\begin{array}{l}0 \\
0 \\
0 \\
0 \\
0\end{array}\right] \ldots$ & $\begin{array}{r}5 \\
5 \\
0 \\
2 \\
12\end{array}$ & $\begin{array}{r}12 \\
9 \\
0 \\
9 \\
30\end{array}$ & $\begin{array}{l}\mathbf{0} \\
\mathbf{6} \\
\mathbf{3} \\
\mathbf{0} \\
\mathbf{9}\end{array}$ & $\begin{array}{r}12 \\
15 \\
2 \\
13 \\
41\end{array}$ & $\begin{array}{l}0 \\
4 \\
2 \\
2 \\
8\end{array}$ & $\begin{array}{r}10 \\
11 \\
2 \\
8 \\
31\end{array}$ & $\begin{array}{l}0 \\
0 \\
0\end{array}$ \\
\hline
\end{tabular}

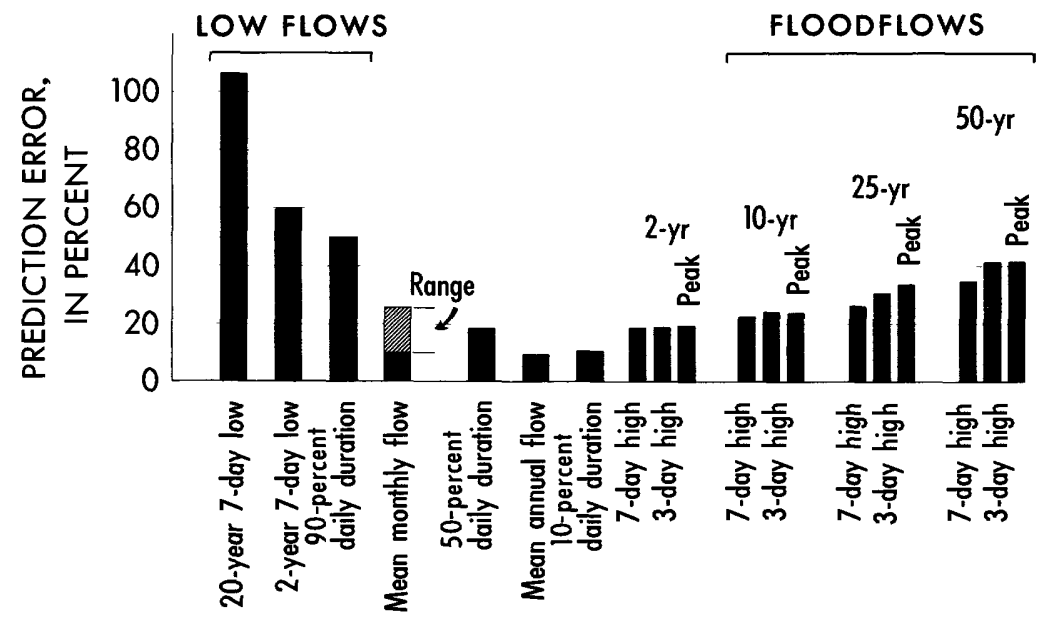

FIgure 13.-Residual errors in Potomac River basin relations. 


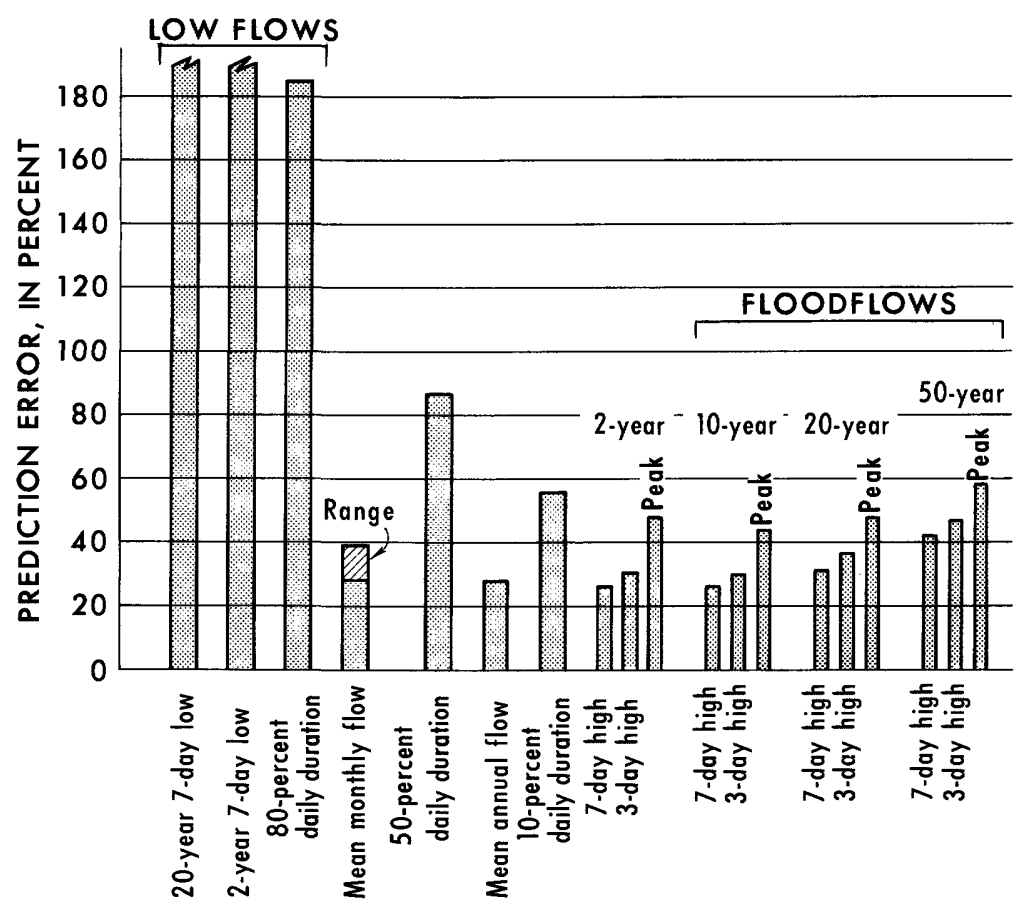

FIGURE 14.-Residual errors in Central region relations.

Accuracy of relations for estimating flow variability (standard deviations) is roughly comparable to the accuracy of relations for estimating mean flows.

\section{APPLICABILITY OF GENERALIZED RELATIONS TO GAGED SITES}

Streamflow information may be required at a gaged site within a region where generalized relations that define streamflow have been obtained. The question then arises of whether to use information provided by the record at the site or, alternatively, to use values calculated from the regression relations. The standard error of estimate provides a measure of the accuracy of the answer from a regression relation. A corresponding measure of error can be computed for any streamflow statistic derived form the actual record. This error varies with the length of record, the nature of the statistic, and its variability. The choice between the two alternatives would be based on comparison between the errors associated with each.

\section{AN ACGURACY TEST OF POTOMAC RIVER RELATIONS}

Accuracy of the streamflow relations as indicated by the standard error was computed from streamflow records used to define the rela- 


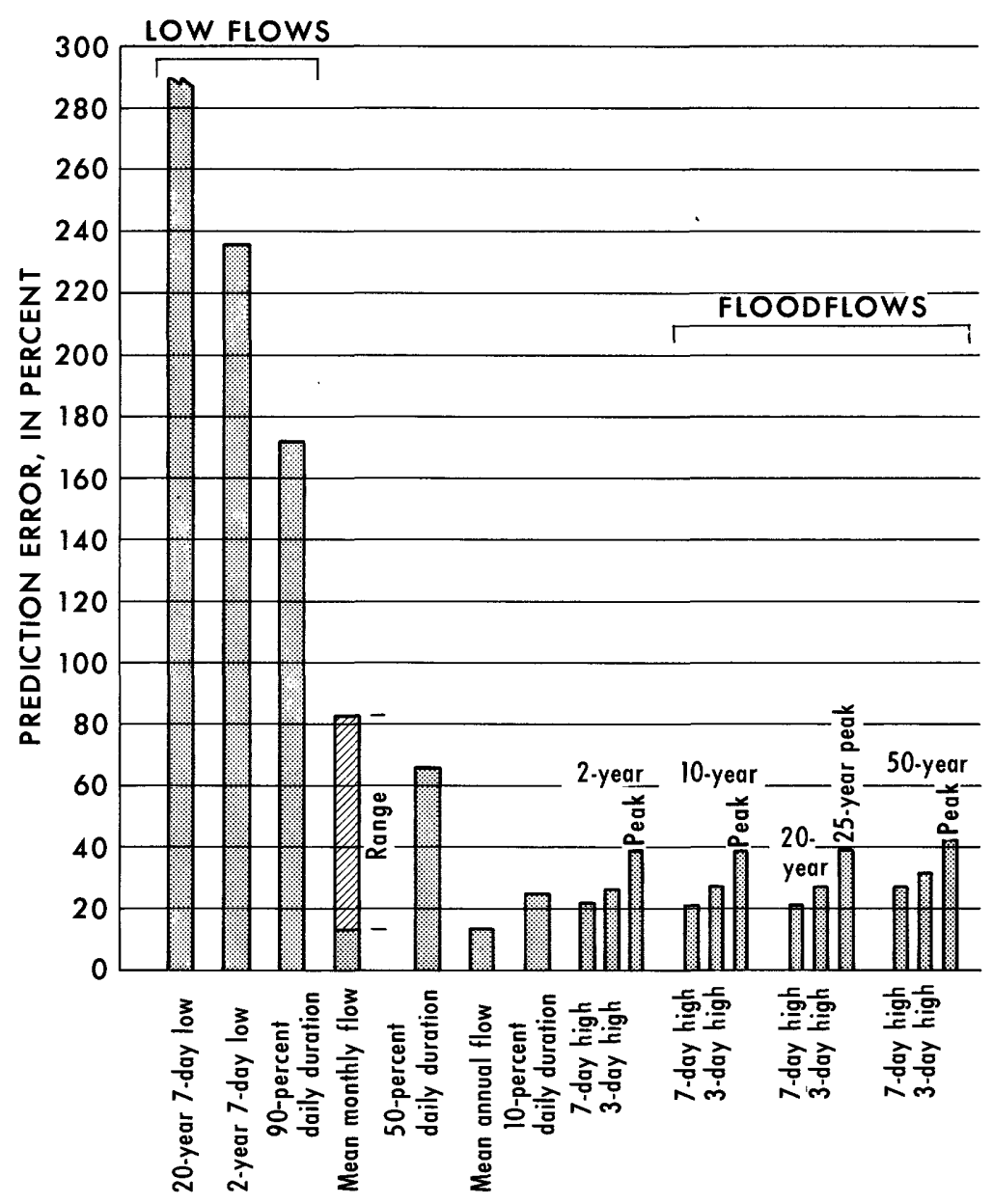

Figure 15.-Residual errors in Southern region relations.

tions. To further test the accuracy of Potomac River basin relations, selected streamflow characteristics of Potomac River basin records not used in the analysis were compared with characteristics computed by the defined relations. In general, these additional records were not included in the original Potomac River basin sample because the records were too short. The streamflow characteristics from these short-term records are therefore less accurately defined, and they may be expected to show a somewhat larger standard error than the computed standard error. Table 11 shows comparative values of predicted and observed streamflow characteristics for the short-record sites. 


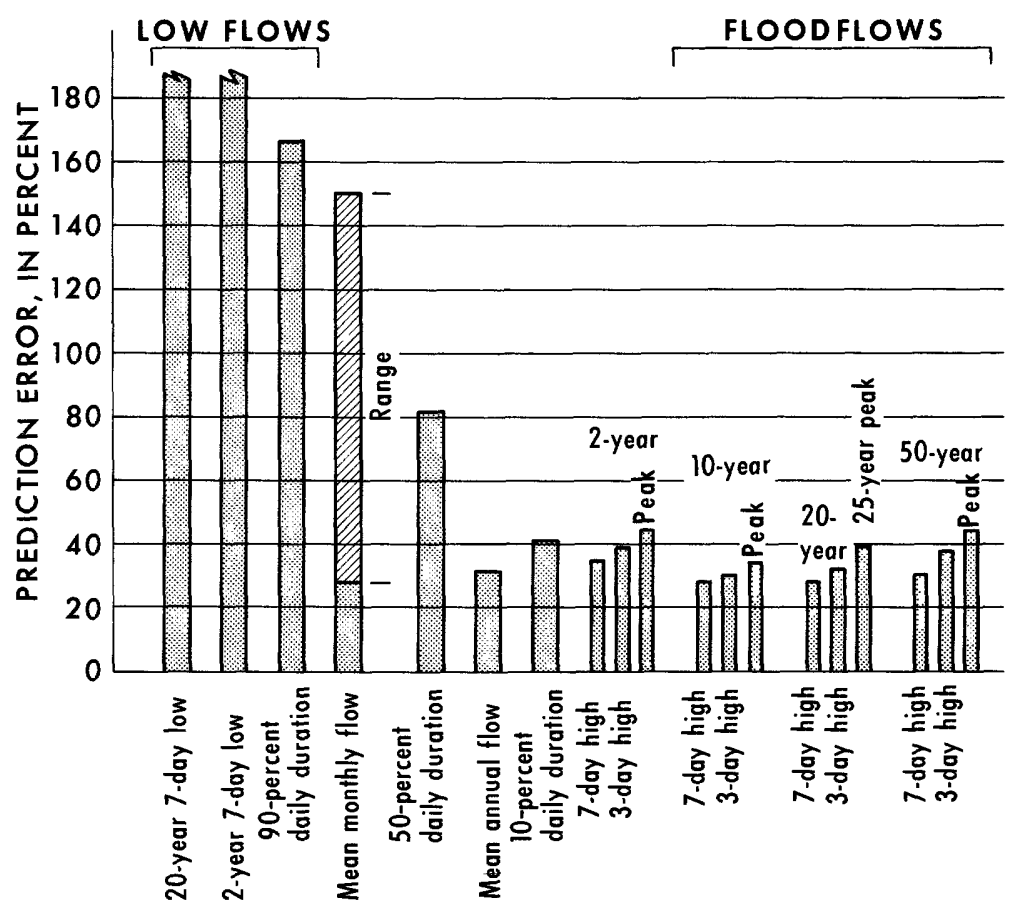

Figure 16.-Residual errors in Western region relations.

\section{IMPLICATIONS IN DESIGN OF DATA-GOLLECTION SYSTEMS}

The natural-flow stream-gaging system of the Geological Survey is operated to provide information for assessing the availability of one of the Nation's natural resources, for planning and design of hydraulic structures, for planning land use, and for answering unanticipated questions on streamflow. The collection system should not be a fixed entity but should change with the current needs for information. There is little point in a large-scale continuing effort to collect data that duplicates, or only insignificantly improves, information already available. If the data-collection system has met some of the needs, it should be altered to meet more efficiently some of the existing needs. The system should also be balanced to provide information on selected streamflow characteristics that is consistent with the needs for that type of information.

The development of multiple-regression relations such as are described here represent the best-known method for using the naturalflow stream-gaging system for providing the existing needs for general information on streamflow. The accuracy provided by a multipleregression relation is expressed by the standard error of estimate. The accuracies for the separate flow characteristics need to be examined 
TABLE 11.-Observed and predicted streamflow characteristics for short-term streamflow record sites in the Potomac River basin

[The upper values are observed discharges, in cubic feet per second; the lower values are discharges estimated from the regression relations]

\begin{tabular}{|c|c|c|c|c|c|c|c|}
\hline Station No. & $M_{7,2}$ & $D_{90}$ & $D_{60}$ & $Q_{A}$ & $D_{10}$ & $V_{1,2}$ & $V_{8,2}$ \\
\hline $\begin{array}{l}6965 \\
6125 \\
6150 \\
6170 \\
6205 \\
6410 \\
6415 \\
6470 \ldots \\
6525 \\
6540 \\
6555 \\
6565 \\
6585 \\
6610\end{array}$ & $\begin{array}{l}2.4 \\
6.9 \\
1.7 \\
2.4 \\
0.1 \\
1.1 \\
4.0 \\
8.0 \\
1.8 \\
1.1 \\
1.1 \\
2.1 \\
2.4 \\
1.7 \\
1.7 \\
0.7 \\
0.1 \\
0.8 \\
1.4 \\
3.0 \\
3.7 \\
2.0 \\
0.4 \\
1.2 \\
3.7 \\
3.1 \\
0.2 \\
0.3 \\
0.8 \\
0.6\end{array}$ & $\begin{array}{l}3.5 \\
7.0 \\
2.1 \\
2.2 \\
0.4 \\
1.1 \\
5.2 \\
6.8 \\
2.0 \\
1.0 \\
1.4 \\
2.0 \\
3.0 \\
1.7 \\
1.9 \\
0.7 \\
0.3 \\
0.6 \\
2.4 \\
2.5 \\
4.3 \\
2.1 \\
0.8 \\
1.2 \\
4.7 \\
3.4 \\
0.3 \\
0.3 \\
1.3 \\
0.6\end{array}$ & $\begin{array}{r}32.5 \\
36.8 \\
13.3 \\
13.8 \\
4.5 \\
5.9 \\
15.5 \\
22.6 \\
6.2 \\
4.5 \\
11.5 \\
14.2 \\
13.2 \\
10.5 \\
7.6 \\
4.9 \\
1.1 \\
2.2 \\
6.1 \\
8.1 \\
14.2 \\
10.0 \\
5.4 \\
5.5 \\
23.8 \\
16.2 \\
2.2 \\
2.1 \\
7.2 \\
3.5\end{array}$ & $\begin{array}{r}74.9 \\
69.2 \\
29.5 \\
23.5 \\
15.6 \\
14.7 \\
37.6 \\
44.0 \\
10.0 \\
9.8 \\
26.9 \\
25.6 \\
24.4 \\
24.9 \\
11.1 \\
11.3 \\
3.3 \\
4.0 \\
14.0 \\
14.6 \\
25.1 \\
23.1 \\
12.4 \\
13.1 \\
48.4 \\
48.0 \\
6.8 \\
5.8 \\
10.7 \\
9.2\end{array}$ & $\begin{array}{r}190 \\
157 \\
70 \\
51 \\
44 \\
34 \\
76 \\
88 \\
23 \\
20 \\
65 \\
58 \\
56 \\
54 \\
25 \\
25 \\
6.5 \\
10.7 \\
26 \\
27 \\
47 \\
44 \\
29 \\
26 \\
102 \\
94 \\
14 \\
11 \\
21 \\
17\end{array}$ & $\begin{array}{r}407 \\
322 \\
157 \\
96 \\
120 \\
120 \\
273 \\
249 \\
36 \\
50 \\
174 \\
170 \\
135 \\
120 \\
45 \\
55 \\
20 \\
20 \\
81 \\
64 \\
145 \\
160 \\
97 \\
80 \\
400 \\
\mathbf{3 1 8} \\
\mathbf{5 2} \\
\mathbf{5 9} \\
50 \\
74\end{array}$ & $\begin{array}{r}654 \\
490 \\
240 \\
172 \\
229 \\
175 \\
494 \\
379 \\
50 \\
85 \\
290 \\
263 \\
183 \\
189 \\
48 \\
85 \\
39 \\
30 \\
149 \\
104 \\
210 \\
240 \\
136 \\
109 \\
678 \\
501 \\
92 \\
88 \\
76 \\
112\end{array}$ \\
\hline
\end{tabular}

to see whether they are satisfactory for the purposes they will serve. Whether or not they are satisfactory can determine the pattern of the future-data-collection system.

Adequate studies to determine accuracy requirements for all uses of water information have not yet been made. Such studies require the incorporation of hydrologic and economic elements and the weighting of all uses to arrive at composite values. Instead of values derived this way, accuracy requirements may now be set in other ways, such as by judgment or by specifying that the accuracies should be equivalent to those obtained by an actual specific length of record. The setting of such accuracies and comparison of them with accuracies obtained by the multiple-regression method provides a firm basis for modification and improvement of the information system.

For instance, if regression relations provide estimates of a flow characteristic within the required accuracy limits, a reduction in effort to collect data on that characteristic would be in order since only enough information to assess long-term changes would be required. Results of 
the regression studies have shown that the midrange of flow is more accurately estimated than the high- or low-flow characteristics. It might; therefore, be found that mean flows can be estimated from regression relations within satisfactory accuracies but that high and low flows cannot. Such a finding would indicate a need for a decreased effort in continuous-record gaging and an increased effort, or change in effort, in partial-record low-flow and crest-stage gaging. In addition, the data-collection system might be improved by collecting information from a sample of basins having as wide a range as possible of those basin characteristics found effective in explaining the variations in flows. One of these characteristics is drainage-area size, and, among other things, this means an increase of gaging in basins with small drainage areas.

The comparison of required accuracies with results of the regression studies will also indicate those areas in which research would be advisable to improve the accuracy of streamflow information; this is particularly true of low-flow information. The research might be in the area of improving the indices used in defining the basin characteristics, in improving the regression model used, or in increasing the knowledge of basic hydrologic processes.

\section{SUMMARY AND CONCLUSIONS}

These studies have tested, for four widely separated study regions, the multiple-regression method of relating streamflow characteristics to drainage-basin characteristics. These analyses used all the virtually natural, long-term streamflow records in each study region. The regression results are, therefore, based upon the most useful natural-flow data available and provide a generalized definition of streamflowone of the principal objectives of the stream-gaging program. In general, it was found that the method produces more accurate relations for the humid Eastern and Southern regions than for the more arid Central and Western regions.

A wide variety of streamflow characteristics were investigated. In all regions it was found that characteristics of the midrange of flows could be estimated more accurately than high-flow characteristics, which, in turn, could be estimated more accurately than low-flow characteristics. Standard errors of estimate for mean annual flow estimates ranged from 8.6 percent for the Eastern region to 33.0 percent for the Western region; relations to estimate low-flow characteristics were of poor accuracy and can provide only rough guides to low-flow magnitudes. Attempts to define relations for estimating skew coefficients and 1-year-lag serial-correlation coefficients of monthly and annual flows were unsuccessful. 
The studies show that the basin-characteristic indices most highly related to streamflow characteristics are drainage-basin size and mean annual precipitation. Forest cover, snow, and surface storage were found to be useful indices in many relations, but the usefulness of these and other indices varied from region to region.

Although some of the criteria needed to use generalization study results for optimal design of a stream-gaging network are yet to be established, the results have a definite value and similar studies are desirable now for all parts of the United States. Such studies lead first to the generalized definition of streamflow-one of the objectives of the stream-gaging program. They also show clearly where information deficiencies exist and where future research effort and concentration of data-collection efforts are needed.

\section{REFERENCES GITED}

Benson, M. A., 1962, Factors influencing the occurrence of floods in a humid region of diverse terrain: U.S. Geol. Survey Water-Supply Paper 1580-B, $64 \mathrm{p}$.

- 1964, Factors affecting the occurrence of floods in the Southwest: U.S. Geol. Survey Water-Supply Paper 1580-D, 72 p.

Busby, M. W., and Benson, M. A., 1960, Grid method of determining mean flow distance in a drainage basin: Internat. Assoc. Sci. Hydrol. Bull. 20, p. 32.

California Department of Water Resources, 1965, Snow Survey measurements through 1965 : Bull. 129, $365 \mathrm{p}$.

Chow, Ven Te, 1962, Hydrologic determination of waterway areas for the design of drainage structures in small drainage basins: Univ. Illinois Eng. Expt. Sta. Bull. 462.

Dalrymple, Tate, 1960, Flood-frequency analyses: U.S. Geol. Survey WaterSupply Paper 1543-A, 80 p.

Dawdy, D. R., and Langbein, W. B., 1960, Mapping mean areal precipitation: Internat. Assoc. Sci. Hydrol. Bull. 19, p. 16-23.

Fenneman, N. M., 1938, Physiography of Eastern United States: New York, McGraw-Hill Book Co., 691 p.

Flora, S. D., 1948, Climate of Kansas: Kansas Board Agriculture Rept, v. 67, no. $285,320 \mathrm{p}$.

Horton, R. E., 1932, Drainage-basin characteristics : Am. Geophys. Union Trans., p. 350-361.

Linsley, R. K., Jr., Kohler, M. A., and Paulhus, J. L. N., 1949, Applied hydrology : New York, McGraw-Hill Book Co., 689 p.

Riggs, H. C., 1965, Estimating probability distributions of drought flows: Water and Sewage Works, v. 112, no. 5, p. 153-157.

U.S. Soil Conservation Service, 1956, Engineering handbook, hydrology, supplement A, section 4 : Washington, U.S. Dept. Agriculture.

U.S. Weather Bureau, 1952, Mean number of thunderstorm days in the United States: Tech. Paper 19, 23 p.

-1958, Rainfall intensity-frequency regime, part 3, the middle Atlantic region : Tech. Paper 29,38 p.

1959-61, Climates of the States: U.S. Weather Bureau, Climatography of the United States, no. 60 [section for each State].

1961, Rainfall frequency atlas of the United States: Tech. Paper 40, $115 \mathrm{p}$.

U.S. GOVERNMENT PRINTING OFFICE: 1970 O-378-463 
